National Water Census

\title{
Estimated Use of Water in the Delaware River Basin in Delaware, New Jersey, New York, and Pennsylvania, 2010
}

Scientific Investigations Report 2015-5142 
Cover. Photograph of the Delaware River by Heather Siple (http://sipleart.com/). 


\section{Estimated Use of Water in the Delaware River Basin in Delaware, New Jersey, New York, and Pennsylvania, 2010}

By Susan S. Hutson, Kristin S. Linsey, Russell A. Ludlow, Betzaida Reyes, and Jennifer L. Shourds

National Water Census

Scientific Investigations Report 2015-5142 


\title{
U.S. Department of the Interior SALLY JEWELL, Secretary
}

\section{U.S. Geological Survey Suzette M. Kimball, Director}

\section{U.S. Geological Survey, Reston, Virginia: 2016}

\author{
For more information on the USGS - the Federal source for science about the Earth, its natural and living resources, \\ natural hazards, and the environment, visit http://www.usgs.gov or call 1-888-ASK-USGS \\ For an overview of USGS information products, including maps, imagery, and publications, \\ visit http://store.usgs.gov \\ To order this and other USGS information products, visit http://store.usgs.gov
}

Any use of trade, product, or firm names is for descriptive purposes only and does not imply endorsement by the U.S. Government.

Although this report is in the public domain, permission must be secured from the individual copyright owners to reproduce any copyrighted materials contained within this report.

Suggested citation:

Hutson, S.S., Linsey, K.S., Ludlow, R.A., Reyes, Betzaida, and Shourds, J.L., 2016, Estimated use of water in the Delaware River Basin in Delaware, New Jersey, New York, and Pennsylvania, 2010: U.S. Geological Survey Scientific Investigations Report 2015-5142, 76 p., http://dx.doi.org/10.3133/sir20155142.

ISSN 2328-0328 (online) 


\section{Contents}

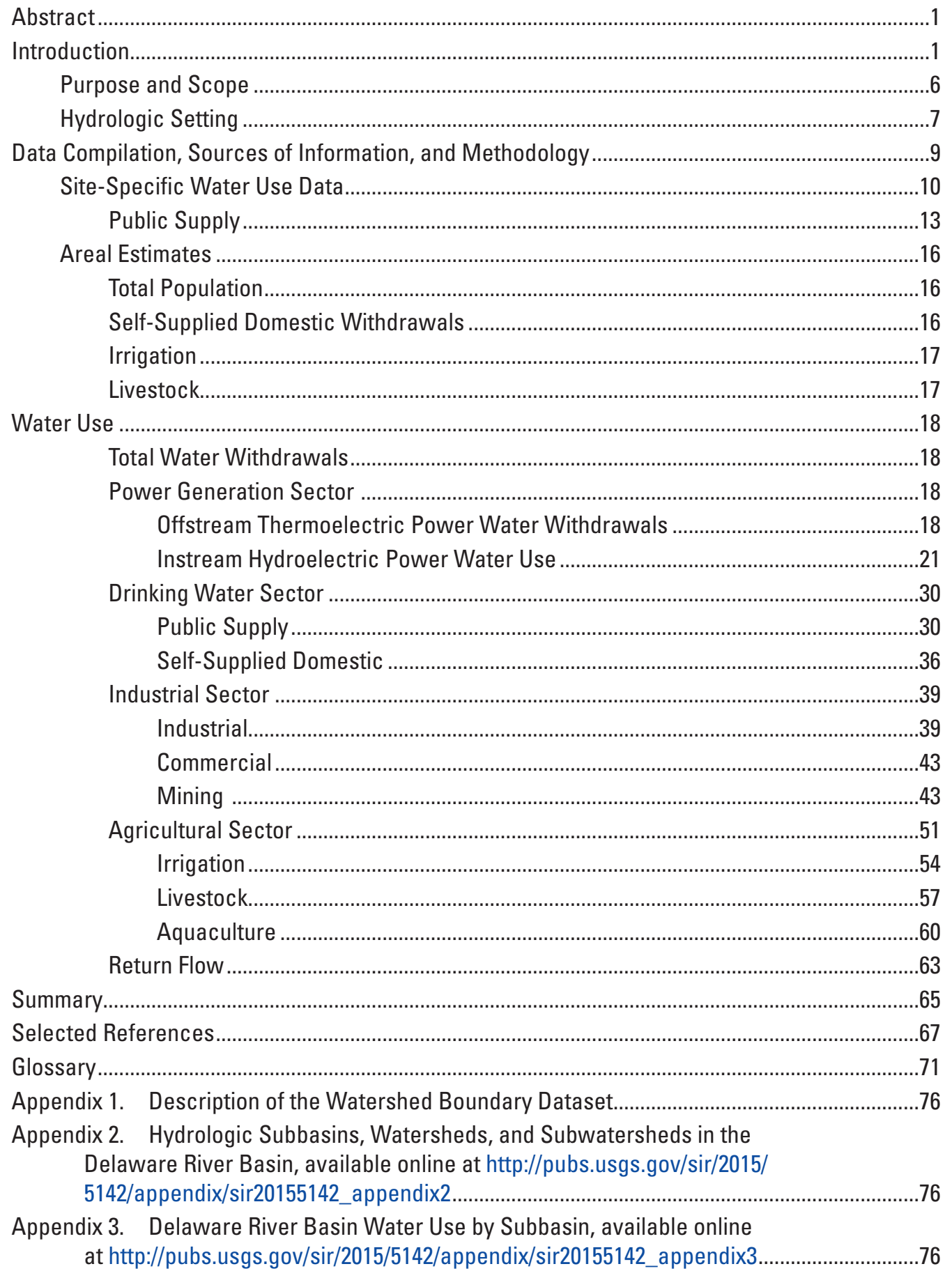




\section{Figures}

1. Map showing major cities and other named locations in the Delaware

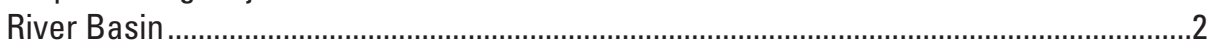

2. Map showing physiographic provinces in the Delaware River Basin ...............................3

3. Map showing major rivers, tributaries, and reservoirs in the Delaware River Basin. .5

4. Map showing principal aquifers and protected areas within the Delaware River Basin .8

5. Map showing basins and subbasins in the Delaware River Basin 12

6. Choropleths showing the number of site-specific data points by year range and subwatershed in the Delaware River Basin, 2010 ...........................................14

7. Map showing counties in the Delaware River Basin ...................................................15

8. Choropleth showing the percentage of subwatershed withdrawals accounted for by areal estimates in the Delaware River Basin, 2010

9. Choropleths showing the distribution of public supply and self-supplied domestic census blocks in the Delaware River Basin, 2010

10. Diagrams showing the distribution of total water withdrawals by $A$, source, $B$, state and sector, and $C$, water use category and state in the Delaware River Basin, 2010

11. Choropleths showing the $A$, total, $B$, surface-water, and $C$, groundwater withdrawals by subbasin in the Delaware River Basin, 2010 .

11a. Choropleths showing the $A$, total, $B$, surface-water, and $C$, groundwater withdrawals by subwatershed in the Delaware River Basin, 2010

12. Choropleth showing the sector with the largest water withdrawals by subwatershed in the Delaware River Basin, 2010.

13. Graphs and choropleths showing the distribution of thermoelectric power generation water withdrawals by $A$, type, basin, state, and $B$, subbasin and subwatershed in the Delaware River Basin, 2010.

14. Diagrams and choropleths showing the distribution of water withdrawals for the Drinking Water sector in the Delaware River Basin, 2010, by $A$, source and basin, $B$, basin and water use category, and $C$, subbasin and source

15. Diagrams showing the distribution of public supply water withdrawals and use by source and state in the Delaware River Basin, 2010.

16. Choropleths showing the public supply water withdrawals, transfers, and use by source, subbasin, and subwatershed in the Delaware River Basin, 2010

17. Choropleths showing the self-supplied domestic groundwater withdrawals by subbasin and subwatershed in the Delaware River Basin, 2010

18. Graph showing the distribution of domestic water withdrawals by state in the Delaware River Basin, 2010.

19. Diagrams and choropleths showing the distribution of water withdrawals for the Industrial sector in the Delaware River Basin, 2010, by $A$, source and basin, $B$, basin and water use category, and $C$, subbasin and source

20. Diagrams showing the distribution of industrial water withdrawals by source and state in the Delaware River Basin, 2010.

21. Choropleths showing the industrial water withdrawals by source, subbasin, and subwatershed in the Delaware River Basin, 2010 
22. Diagrams showing the distribution of commercial water withdrawals

by source and state in the Delaware River Basin, 2010 ..............................................46

23. Choropleths showing the commercial water withdrawals by source, subbasin, and subwatershed in the Delaware River Basin, 2010...

24. Diagrams showing the distribution of mining water withdrawals by source and state in the Delaware River Basin, 2010.

25. Choropleths showing the mining water withdrawals by source, subbasin, and subwatershed in the Delaware River Basin, 2010

26. Diagrams and choropleths showing the distribution of water withdrawals for the Agricultural sector in the Delaware River Basin, 2010 by $A$, source and basin, $B$, basin and water use category, and $C$, subbasin and source.

27. Diagrams showing the distribution of irrigation water withdrawals by source and state in the Delaware River Basin, 2010.

28. Choropleths showing the irrigation water withdrawals by source, subbasin, and subwatershed in the Delaware River Basin, 2010.

29. Diagrams showing the distribution of livestock water withdrawals by source and state in the Delaware River Basin, 2010.

30. Choropleths showing the livestock water withdrawals by source, subbasin, and subwatershed in the Delaware River Basin, 2010.

31. Diagrams showing the distribution of aquaculture water withdrawals by source and state in the Delaware River Basin, 2010

32. Choropleths showing the aquaculture water withdrawals by source, subbasin, and subwatershed in the Delaware River Basin, 2010

33. Choropleths showing the return flows by subbasin and subwatershed in the Delaware River Basin, 2010

34. Diagram showing the number of return-flow sites by state in the Delaware River Basin, 2010

\section{Tables}

1. Topography, geology, and land use of the physiographic provinces of the Delaware River Basin

2. Principal aquifers and associated well characteristics within the Delaware River Basin

3. Water withdrawal reporting thresholds for the States of Delaware, New Jersey, New York, and Pennsylvania, and the Delaware River Basin Commission

4. Summary of data sources by category and type of data, Delaware River Basin, 2010.

5. Total water withdrawals by source and subbasin, Delaware River Basin, 2010

6. Total water withdrawals by source and sector, Delaware River Basin, 2010

7. Total water withdrawals by water use category, Delaware River Basin, 2010

8. Surface-water withdrawals by water use category, Delaware River Basin, 2010 
9. Groundwater withdrawals by water use category, Delaware River Basin, 2010

10. Thermoelectric power water withdrawals, Delaware River Basin, 2010

11. Thermoelectric power generation water withdrawals by basin, Delaware River Basin, 2010

12. Drinking Water sector water withdrawals, Delaware River Basin, 2010

13. Public supply water withdrawals and transfers, Delaware River Basin, 2010

14. Self-supplied domestic water withdrawals, Delaware River Basin, 2010 ........................37

15. Industrial sector water withdrawals, Delaware River Basin, 2010 ….............................40

16. Industrial water withdrawals, Delaware River Basin, 2010 ........................................42

17. Commercial water withdrawals, Delaware River Basin, 2010 .........................................45

18. Mining water withdrawals, Delaware River Basin, 2010 .................................................48

19. Agricultural sector water withdrawals, Delaware River Basin, 2010 ..............................51

20. Irrigation water withdrawals, Delaware River Basin, 2010 ...............................................5

21. Livestock water withdrawals, Delaware River Basin, 2010 ................................................57

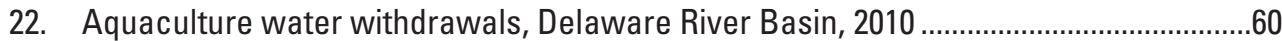

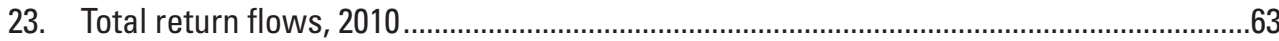

\section{Conversion Factors and Datum}

\begin{tabular}{|c|c|c|}
\hline Multiply & By & To obtain \\
\hline \multicolumn{3}{|c|}{ Length } \\
\hline inch (in.) & 2.54 & centimeter $(\mathrm{cm})$ \\
\hline foot $(\mathrm{ft})$ & 0.3048 & meter $(\mathrm{m})$ \\
\hline mile (mi) & 1.609 & kilometer $(\mathrm{km})$ \\
\hline \multicolumn{3}{|c|}{ Area } \\
\hline square mile $\left(\mathrm{mi}^{2}\right)$ & 259.0 & hectare (ha) \\
\hline square mile $\left(\mathrm{mi}^{2}\right)$ & 2.590 & square kilometer $\left(\mathrm{km}^{2}\right)$ \\
\hline \multicolumn{3}{|c|}{ Volume } \\
\hline gallon (gal) & 3.785 & liter (L) \\
\hline gallon (gal) & 3.785 & cubic decimeter $\left(\mathrm{dm}^{3}\right)$ \\
\hline million gallons (Mgal) & 3,785 & cubic meters $\left(\mathrm{m}^{3}\right)$ \\
\hline million gallons (Mgal) & 3.07 & acre-feet (acre-ft) \\
\hline acre-foot (acre-ft) & 1,233 & cubic meter $\left(\mathrm{m}^{3}\right)$ \\
\hline acre-foot (acre-ft) & 325,851 & gallons (gal) \\
\hline acre-foot (acre-ft) & 43,450 & cubic feet $\left(\mathrm{ft}^{3}\right)$ \\
\hline \multicolumn{3}{|c|}{ Flow rate } \\
\hline acre-foot per year (acre-ft/yr) & 1,233 & cubic meter per year $\left(\mathrm{m}^{3} / \mathrm{yr}\right)$ \\
\hline cubic foot per second $\left(\mathrm{ft}^{3} / \mathrm{s}\right)$ & 0.02832 & cubic meter per second $\left(\mathrm{m}^{3} / \mathrm{s}\right)$ \\
\hline gallon per minute (gal/min) & 0.06309 & liter per second $(\mathrm{L} / \mathrm{s})$ \\
\hline gallon per day (gal/d) & 0.003785 & cubic meter per day $\left(\mathrm{m}^{3} / \mathrm{d}\right)$ \\
\hline million gallons per day (Mgal/d) & 0.04381 & cubic meter per second $\left(\mathrm{m}^{3} / \mathrm{s}\right)$ \\
\hline inch per year (in/yr) & 25.4 & millimeter per year (mm/yr) \\
\hline
\end{tabular}

Horizontal coordinate information is referenced to the North American Datum of 1983 (NAD 83).

Altitude, as used in this report, refers to distance above the vertical datum. 


\section{Acronyms}

$\begin{array}{ll}\text { ASR } & \text { Aquifer Storage and Recovery } \\ \text { CDL } & \text { Cropland Data Layer } \\ \text { DRB } & \text { Delaware River Basin } \\ \text { DRBC } & \text { Delaware River Basin Commission } \\ \text { ECHO } & \text { Enforcement and Compliance History Online } \\ \text { EPA } & \text { U.S. Environmental Protection Agency } \\ \text { GIS } & \text { Geographic Information System } \\ \text { HUC } & \text { Hydrologic Unit Code } \\ \text { NWIS } & \text { National Water Information System } \\ \text { NRCS } & \text { Natural Resources Conservation Service } \\ \text { SECURE } & \text { Science and Engineering to Comprehensively Understand and Responsibly } \\ \text { USCB } & \text { Enhance } \\ \text { USDA } & \text { U.S. Census Bureau } \\ \text { USGS } & \text { U.S. Department of Agriculture } \\ \text { WBD } & \text { U.S. Geological Survey } \\ & \text { Watershed Boundary Dataset }\end{array}$





\title{
Estimated Use of Water in the Delaware River Basin in Delaware, New Jersey, New York, and Pennsylvania, 2010
}

\author{
By Susan S. Hutson, Kristin S. Linsey, Russell A. Ludlow, Betzaida Reyes, and Jennifer L. Shourds
}

\section{Abstract}

The Delaware River Basin (DRB) was selected as a Focus Area Study in 2011 by the U.S. Geological Survey (USGS) as part of the USGS National Water Census. The National Water Census is a USGS research program that focuses on national water availability and use and then develops new water accounting tools and assesses water availability at both the regional and national scales. One of the water management needs that the DRB study addressed, and that was identified by stakeholder groups from the DRB, was to improve the integration of state water use and water-supply data and to provide the compiled water use information to basin users. This water use information was also used in the hydrologic modeling and ecological components of the study.

Instream and offstream water use was calculated for 2010 for the DRB based on information received from Delaware, New Jersey, New York, and Pennsylvania. Water withdrawal, interbasin transfers, return flow, and hydroelectric power generation release data were compiled for 11 categories by hydrologic subregion, basin, subbasin, and subwatershed. Data availability varied by state. Site-specific data were used whenever possible to calculate public supply, irrigation (golf courses, nurseries, sod farms, and crops), aquaculture, selfsupplied industrial, commercial, mining, thermoelectric, and hydroelectric power withdrawals. Where site-specific data were not available, primarily for crop irrigation, livestock, and domestic use, various techniques were used to estimate water withdrawals.

Total water withdrawals in the Delaware River Basin were calculated to be about 7,130 million gallons per day (Mgal/d) in 2010. Calculations of withdrawals by source indicate that freshwater withdrawals were about 4,130 Mgal/d (58 percent of the total) and the remaining 3,000 Mgal/d (42 percent) were from saline water. Total surface-water withdrawals were calculated to be $6,590 \mathrm{Mgal} / \mathrm{d}$, or 92 percent of the total; about 54 percent $(3,590 \mathrm{Mgal} / \mathrm{d})$ of surface water withdrawn was freshwater. Total groundwater withdrawals were calculated to be $545 \mathrm{Mgal} / \mathrm{d}$ (8 percent of the total), all of which was freshwater. During 2010, calculated withdrawals by category, in decreasing order, were: thermoelectric power,
4,910 Mgal/d; public supply, 1,490 Mgal/d; self-supplied industrial, $350 \mathrm{Mgal} / \mathrm{d}$; irrigation, $175 \mathrm{Mgal} / \mathrm{d}$; self-supplied domestic, $117 \mathrm{Mgal} / \mathrm{d}$; mining, $41.3 \mathrm{Mgal} / \mathrm{d}$; aquaculture, $19.3 \mathrm{Mgal} / \mathrm{d}$; livestock, $6.72 \mathrm{Mgal} / \mathrm{d}$, and commercial, $5.89 \mathrm{Mgal} / \mathrm{d}$. The amount of instream use for hydroelectric power generation purposes in 2010 was reported to be $273 \mathrm{Mgal} / \mathrm{d}$ for the Wallenpaupack Plant and $127 \mathrm{Mgal} / \mathrm{d}$ for the Mongaup River system.

Total return flows in the DRB were $2,960 \mathrm{Mgal} / \mathrm{d}$ in 2010. Although municipal wastewater-treatment plants accounted for 539 (97 percent) of the return-flow sites, they accounted for about 70 percent of the total return flows in the DRB. There was limited information on return flows from thermoelectric power.

\section{Introduction}

The Delaware River Basin study area contains 13,539 square miles $\left(\mathrm{mi}^{2}\right)$, draining parts of Pennsylvania $\left(6,422 \mathrm{mi}^{2}\right.$ or 50.3 percent of the basin's ${ }^{1}$ total land area); New Jersey $\left(2,969 \mathrm{mi}^{2}, 23.3\right.$ percent); New York $\left(2,362 \mathrm{mi}^{2}\right.$, 18.5 percent); Delaware (1,004 $\mathrm{mi}^{2}, 7.9$ percent), and includes Delaware Bay (782 $\left.\mathrm{mi}^{2}\right)$ (fig.1). In 2010, the population in the DRB was 8.2 million. The Appalachian Plateaus, Valley and Ridge, New England, Piedmont, and Coastal Plain are the major physiographic provinces in the DRB (Fischer and others, 2004; fig. 2, table 1). The northern provinces are relatively unpopulated. The Appalachian Plateaus Province contains 1,000- to 4,000-feet (ft)-high mountains that are mostly forested. The Valley and Ridge and New England Physiographic Provinces are composed of valleys with some urban and agricultural development, and mostly undeveloped 1,000-ft-high linear ridges. About 80 percent of the population in the basin lives in the southern half of the basin, which is composed of the rolling hills of the Piedmont Province, and the relatively flat Coastal Plain.

\footnotetext{
${ }^{1}$ Words and phrases introduced in bold are listed in the Glossary.
} 


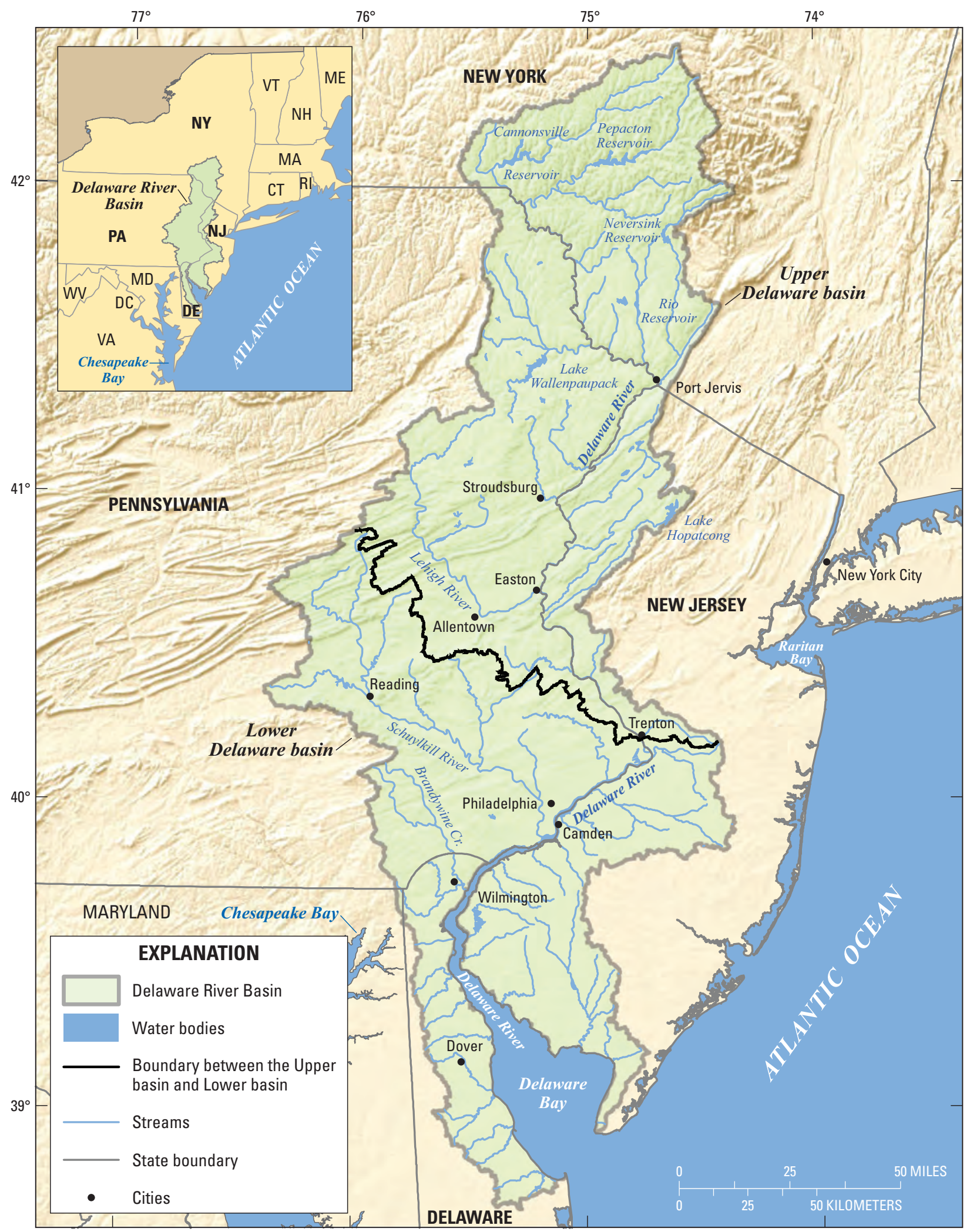

Shaded relief base from U.S. Geological Survey, National Map, 2014.

State boundaries from U.S. Geological Survey, 1983.

Water features from U.S. National Atlas, 2014.

Cities from U.S. Census, 2000.

Albers Equal-Area Conic Projection.

Figure 1. Major cities and other named locations in the Delaware River Basin. 


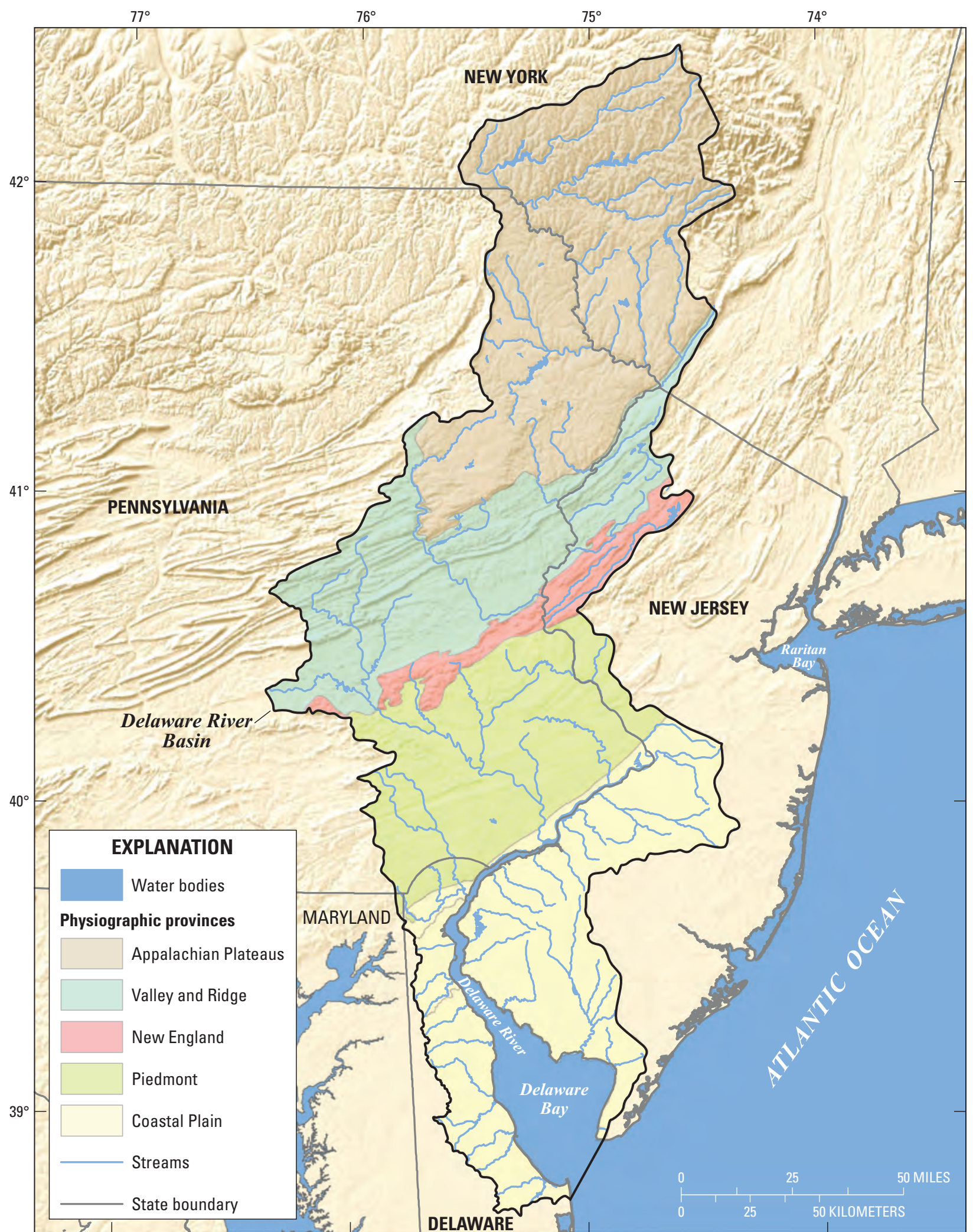

Shaded relief base from U.S. Geological Survey, National Map, 2014.

State boundaries from U.S. Geological Survey, 1983.

Physiographic provinces modified from

Water features from U.S. National Atlas, 2014

Parker and others, 1964.

Albers Equal-Area Conic Projection.

Figure 2. Physiographic provinces in the Delaware River Basin. 
Table 1. Topography, geology, and land use of the physiographic provinces of the Delaware River Basin (Fischer and others, 2004; Vigil and others, 2000).

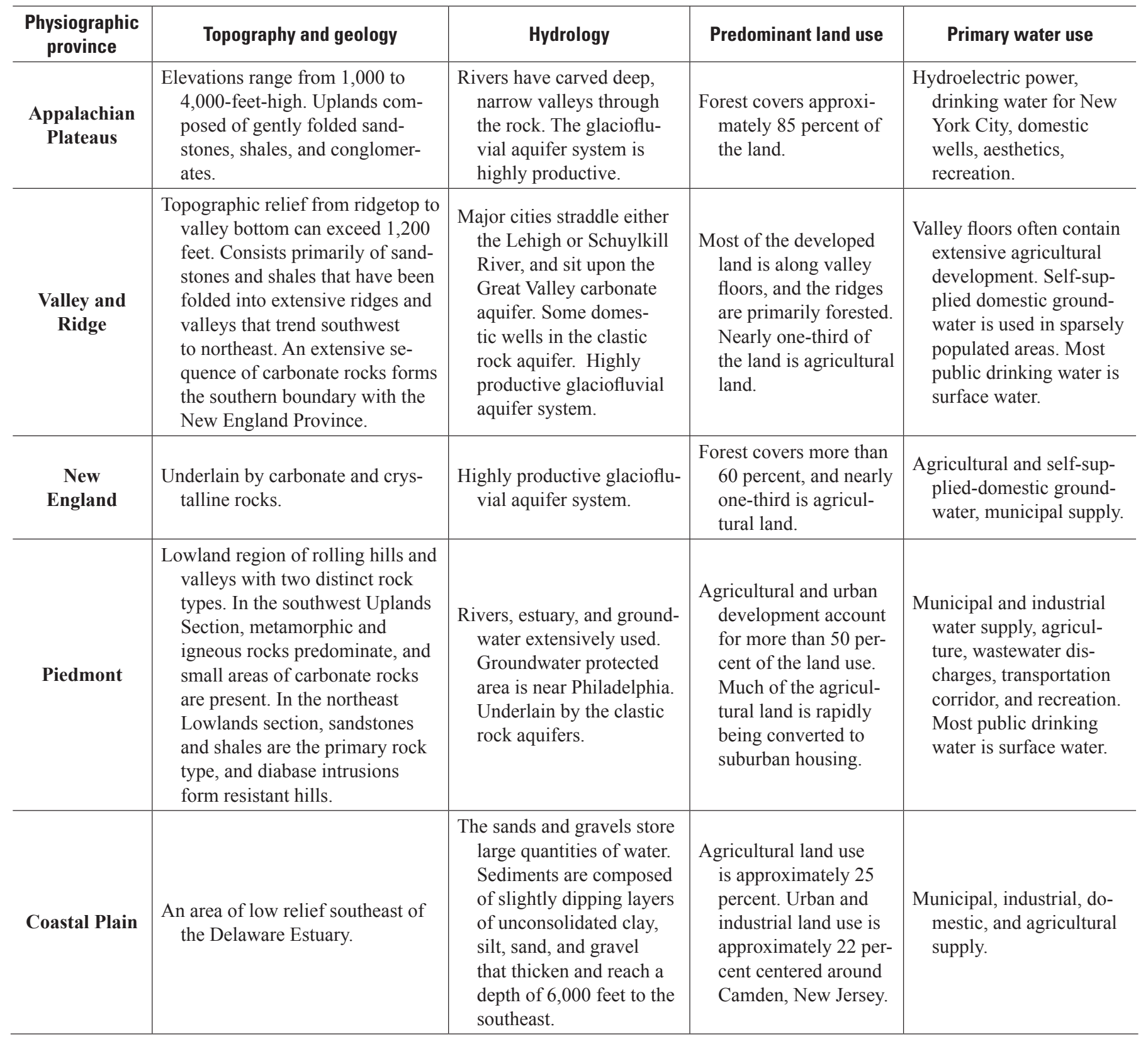

Differences in topography, geology, and hydrology have mostly determined land-use patterns, and consequently, water availability and water use (table 1). Because of its relatively high topographic relief, the northern half of the basin is home to several large water-supply and hydroelectric reservoirs (fig. 3). Further south, in the Piedmont and Coastal Plain Provinces where most people live, public supply (also known as municipal supply) and self-supplied domestic water use are the highest uses (Fischer and others, 2004). Supplies in the Piedmont Province are mostly from surface-water sources, whereas most of the supply in the Coastal Plain Province comes from the highly productive aquifers. The drinking water supply in the Valley and Ridge Province is almost split equally between surface-water and groundwater sources. Many cities on major rivers, such as the Delaware, Lehigh, Schuylkill, and Brandywine, draw their drinking water directly from the river. Residents in sparsely populated areas of the basin rely on domestic wells as a source of drinking water.

Past interstate water conflicts have resulted in several court decisions, and the Delaware River Basin Commission (DRBC) was created in 1961 to help resolve disputes. As a result of Supreme Court decisions, three reservoirs in the upper basin can export up to 800 million gallons per day (Mgal/d) to New York City, and the Delaware and Raritan 


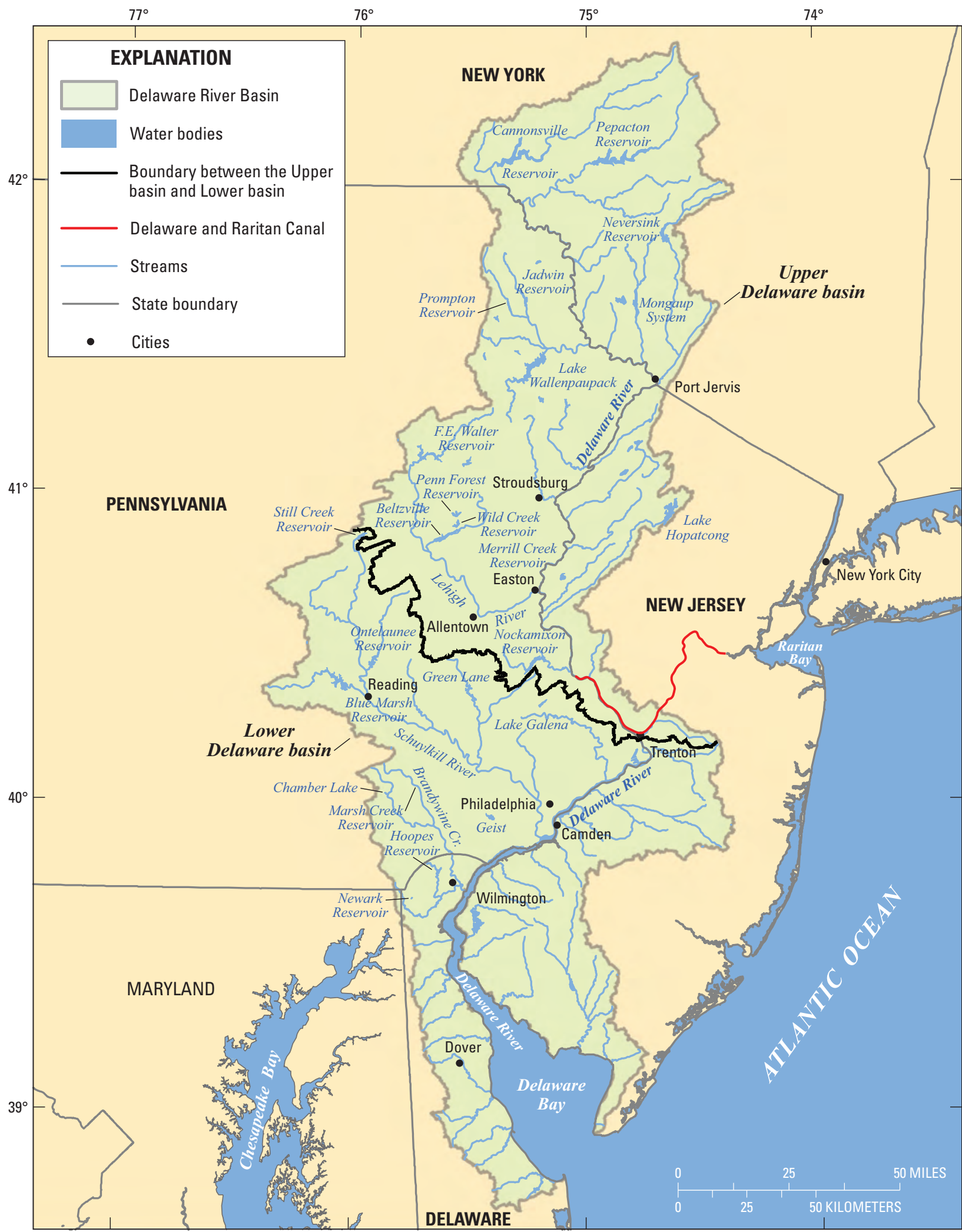

State boundaries from U.S. Geological Survey, 1983.

Water features from U.S. National Atlas, 2014, and Delaware River Basin Commission, 2008.

Cities from U.S. Census, 2000.

Albers Equal-Area Conic Projection.

Figure 3. Major rivers, tributaries, and reservoirs in the Delaware River Basin. 
Estimated Use of Water in the Delaware River Basin in Delaware, New Jersey, New York, and Pennsylvania, 2010

Canal in central New Jersey can export up to $100 \mathrm{Mgal} / \mathrm{d}$ to northern New Jersey water purveyors (fig. 3). These exports supply over 8 million people outside the basin. Flow on the main-stem Delaware River is managed in accordance with the 1954 Supreme Court Decree that specifies a minimum flow requirement of 1,750 cubic feet per second $\left(\mathrm{ft}^{3} / \mathrm{s}\right)$ at Montague, New Jersey. A 1983 Agreement among the Parties to the Decree established a minimum flow requirement of $3,000 \mathrm{ft}^{3} / \mathrm{s}$ at Trenton, New Jersey. More recently, a flexible flow management plan, negotiated by the DRBC, the States, and New York City, allows for modified releases from the upper basin reservoirs to address competing needs and uses that include: safe and reliable water supplies to serve the needs of more than 17 million people; water management during droughts; flood mitigation; protection of cold water fisheries; controlling salinity incursion in the estuary; and maintaining a diverse array of habitat needs in the main stem Delaware River, Estuary, and Bay (U.S. Geological Survey, 2014a).

Recent water-supply concerns that have emerged in the DRB include (1) the water needs of growing populations in the Pocono Mountains and selected watersheds surrounding the Delaware Bay, (2) proposed energy-production activities in groundwater-dependent watersheds, (3) the possibility of growth in the Thermoelectric and Irrigation sectors, and (4) the yet-unknown instream needs of aquatic ecosystems. Migration of the salt line into the upper estuary and its potential to increase sodium concentrations in public water-supply intakes is also a concern (Partnership for the Delaware Estuary, 2012). During the drought of record in the 1960s, the salt line was near river mile 102 and affected public supply wells in Camden, New Jersey and approached the nearby public supply intake for Philadelphia. In addition, recent concerns about excessive groundwater withdrawals to meet growing demands have resulted in regulatory action to remedy declining groundwater levels through conjunctive management of supplies in northern Delaware. Residents of the Appalachian Plateaus and Coastal Plain Provinces are particularly dependent on groundwater for public supply and self-supplied domestic use. In comparison, residents of the Valley and Ridge, Piedmont, and New England Provinces are more dependent on surface water for a large part of their drinking water. Residents in the most sparsely populated areas in the basin rely on domestic wells as a source of drinking water. In south-central New Jersey, reductions in aquifer withdrawals in a designated critical area (fig. 4) have been mandated in response to large drawdowns in the aquifer, and the DRBC has instituted additional groundwater permit requirements in southeastern Pennsylvania due to concerns about overuse.

Estimates of groundwater availability from the aquifers were determined by 10-digit watershed for the Delaware River Basin (Sloto and Buxton, 2006). Estimated 2-year, 5-year, 10-year, 25-year, and 50-year annual base-flow recurrence interval values for each watershed were considered to be the groundwater available for each watershed over a range of climatic conditions. The results showed that from 1997 to 2000, groundwater use ranged from 0 to 127 percent of available groundwater for the 50-year occurrence interval, which represents the drier years.

Recognizing these water availability and water use concerns, the U.S. Geological Survey's (USGS) National Water Census selected the DRB as a Focus Area Study in 2011 (Alley and others, 2013). The National Water Census is a USGS research program that focuses on national water availability and use and then develops new water accounting tools and assesses water availability at both the regional and national scales (U.S. Geological Survey, 2014b). Through the National Water Census, the USGS is integrating diverse research on water availability and use and enhancing the understanding of the connection between water quality and water availability. Research is designed to build decisionsupport capacity for water management agencies and other natural resource managers. The National Water Census is one of six major science directions identified by the USGS in its 2007 Science Plan (U.S. Geological Survey, 2007), called for in the SECURE (Science and Engineering to Comprehensively Understand and Responsibly Enhance) Water Act, and implemented through the Department of the Interior WaterSMART (Sustain and Manage America's Resources for Tomorrow) initiative (U.S. Geological Survey, 2014e).

The USGS Water Census Focus Area Study in the DRB will concentrate on providing information to stakeholders in the basin, and will contribute to science and water management needs in the basin. Among the needs identified by stakeholder groups that the study will address are: (1) improving the integration of state water use and water-supply data; (2) developing a basinwide surface-water hydrologic model capable of evaluating the impacts of land-use change, climate change, and changes in water demand; and (3) developing a scientific approach to defining relations between streamflow processes and the responses of aquatic organisms in tributary streams. Compiled water use information in this report will address the first need identified above by providing water use information to basin users. This water use information will also be used in the hydrologic modeling and ecological components of the study.

\section{Purpose and Scope}

This report presents instream and offstream water use estimates from 2010 for the DRB in Delaware, New Jersey, New York, and Pennsylvania (fig. 1). Estimates are not provided for the 8- $\mathrm{mi}^{2}$ section of Maryland that is in the basin. Site-specific water withdrawal and return flow data from the four states were compiled, and areal estimates of non-reported uses were made. Estimates of consumptive use were not made. Water use data are aggregated to the DRB 4-digit subregions, 6-digit basins, 8-digit subbasins, and 12-digit subwatersheds. The 6-digit basin 020401 (Upper Delaware) is also referred to in this report as the Upper basin; 020402 (Lower Delaware) is referred to as the Lower basin. The boundary between the Upper basin and the Lower basin is shown in figure 1 . The presentation of instream water use is limited to the release of water from the Wallenpaupack 
(Pennsylvania) and Rio (New York) reservoirs for the production of hydroelectric power, and excludes releases of water from reservoirs to maintain water temperatures, flows for wildlife, and other downstream uses such as managing the location of the salt line and navigation.

The report contains a section on total water use in the basin along with other sections that present more detailed information on each water use category by basin and subbasin. The Power Generation section contains thermoelectric power and hydroelectric power uses; the Drinking Water section contains public supply and domestic uses; the Industrial section contains self-supplied industrial, commercial, and mining uses; and the Agricultural section contains irrigation, livestock, and aquaculture uses. Appendix 1 describes the Watershed Boundary Dataset (WBD) that defines the areal extent and the hydrologic classification of the basins, subbasins, watersheds, and subwatersheds in the DRB. Appendix 2 lists the subbasin, watershed, and subwatershed names and corresponding 8-digit, 10-digit, and 12-digit hydrologic unit codes. Appendix 3 summarizes water use by subbasin according to source of water and water use category. The 8-digit subbasin and 12-digit subwatershed data for all categories in this report may be downloaded from http://dx.doi.org/10.5066/ F7TM787C.

The terms and units used in this report are similar to those used in previous USGS water use reports (MacKichan, 1951, 1957; MacKichan and Kammerer, 1961; Murray, 1968; Murray and Reeves, 1972, 1977; Solley and others, 1983, 1988, 1993, 1998; Hutson and others, 2004; Kenny and others, 2009) and are defined in the Glossary at the end of the report. Units of millions of gallons per day do not represent actual daily rates, but rather are used to express total amounts as an average daily rate for a period of 1 year. For example, irrigation water may be applied only during parts of the year and at variable rates; therefore, the actual rate of application at any given time during the growing season is different from the average daily rate based on 365 days in a year.

The water use data in this report are rounded to three significant figures. All values are rounded independently, so the sums of individual rounded numbers may not equal the totals. Percentage changes discussed in the text are calculated from the unrounded data and are expressed as integers. All population data are rounded to three significant figures.

Choropleths by subbasin (8-digit hydrologic units) use similar ranges to facilitate comparison across sectors and categories. Choropleths by subwatershed (12-digit hydrologic units) use ranges that highlight variations among the subwatersheds. The minimum and maximum range values are adjusted to reflect actual estimates by category.

Water withdrawals in this report were compiled as freshwater or saline. Interbasin water transfers are limited to the major interbasin transfers of water from the Upper Delaware Basin to the Hudson Basin, from the Lower Delaware Basin through the Delaware-Raritan Canal to the Raritan Basin, and from the Susquehanna Basin to the Lower Delaware Basin. Public wastewater, industrial, thermoelectric, irrigation, and other return flows are reported by hydrologic subregion, basin, subbasin, and subwatershed.

\section{Hydrologic Setting}

The headwaters of the Delaware River (fig. 3) are in New York in the Catskill Mountains of the Appalachian Plateaus Physiographic Province. The Delaware River is formed at the confluence of the West Branch Delaware River and the East Branch Delaware River. From the confluence, the river flows 220 miles south to the Delaware Estuary, which extends from Trenton, New Jersey to the Delaware Bay. The river is fed by several principal tributaries - in New York, the Mongaup and Neversink Rivers and Callicoon Creek; in Pennsylvania, the Lackawaxen, Lehigh, and Schuylkill Rivers and Broadhead Creek; in New Jersey, the Musconetcong, Cooper, and Maurice Rivers and Rancocas Creek; and in Delaware, the Brandywine Creek-Christina River. The Delaware River is the longest undammed river east of the Mississippi River, but flow is regulated by large reservoirs that were constructed for water supply, power generation, flood control, and streamflow augmentation. Water releases are coordinated through the flexible flow management program. Approximately 1,500 smaller dams regulate tributary flow throughout the watershed (Partnership for the Delaware Estuary, 2012), many of which were built as mill dams, or for cutting ice in winter. Many of these small dams are now filled with sediment, and as a result have little effect on flow (Ronald Sloto, USGS, oral commun., June 16, 2014).

Precipitation in the DRB varies geographically, and from year to year. Average annual precipitation ranges from 50 inches (in.) in the higher elevation north to 42 in. in the south (Jenner and Lins, 1991). Average monthly precipitation varies little by season, but precipitation-producing mechanisms change with the season. In the winter, high rainfall is associated with storms moving parallel to the Atlantic Coast from the Gulf of Mexico, and in the summer, Bermuda highs circulate moist air into the area and create scattered convective showers. Occasionally tropical storms move into the area. The most important local influence is terrain. The orthography of the Catskill and Pocono Mountains can lead to great variability in precipitation characteristics over small areas.

The principal aquifers in the DRB north of the Coastal Plain are composed of carbonate, igneous metamorphic, and siliciclastic (including sandstone, shale, and slate) rock, whereas the Coastal Plain is a semiconsolidated sand aquifer (fig. 4). A glaciofluvial aquifer system (not a principal aquifer), composed of unconsolidated sands, silts, and clays, fills many of the valleys in the Appalachian Plateaus, Valley and Ridge, and New England Physiographic Provinces. Depending on the extent and thickness, the glacial aquifer can be highly productive in places. Carbonate aquifers are an important source of water in the Valley and Ridge and New England Provinces. Less extensive carbonate aquifers in the Piedmont and Appalachian Plateaus can also be locally important sources of water. Less productive siliciclastic rock aquifers underlie much of the Appalachian Plateaus, Valley and Ridge, and Piedmont Physiographic Provinces. The Coastal Plain aquifers are composed of thick sequences of unconsolidated sand 


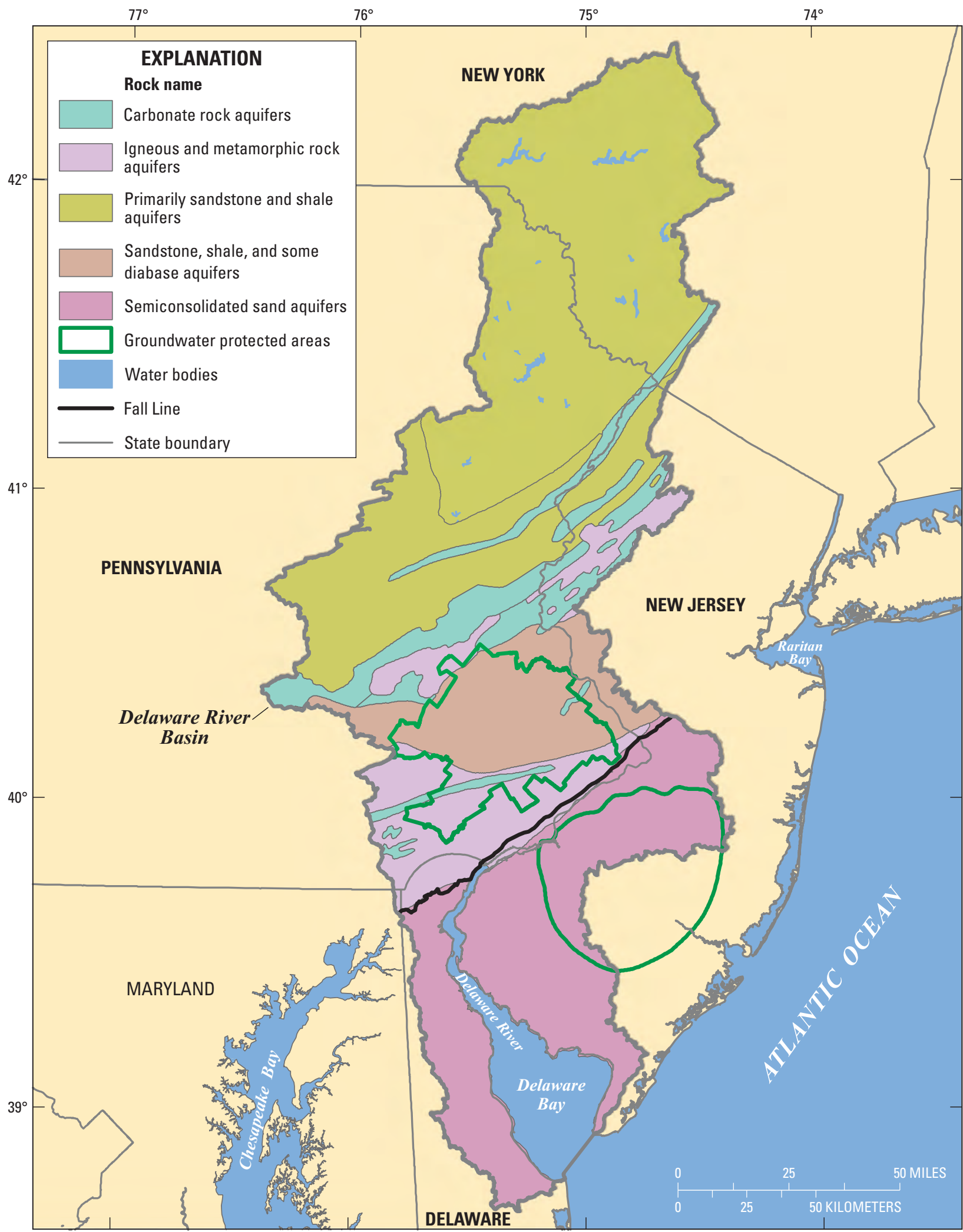

Aquifers from U.S. Geological Survey, 2003

State boundaries from U.S. Geological Survey, 1983.

Water features from U.S. National Atlas, 2014.

Groundwater protected areas from Delaware River Basin Commission, 2014.

Fall Line from compilation of exisiting Delaware, Maryland, New Jersey, and Pennsylvania State geologic datasets, 2013. Albers Equal-Area Conic Projection.

Figure 4. Principal aquifers and protected areas within the Delaware River Basin. 
that are highly productive. A comparison of aquifer and well characteristics of the local formations show that the sands and gravels of the semiconsolidated stratum of the Coastal Plain have wells that may yield 1,000 gallons per minute ( $\mathrm{gal} / \mathrm{min})$, and the wells may be deep as 2,000 $\mathrm{ft}$ (table 2).

\section{Data Compilation, Sources of Information, and Methodology}

State water use programs and the DRBC determine water reporting criteria for the water users within the Delaware River Basin (table 3). Reporting thresholds vary from state to state from 10,000 gallons per day (gal/d) to $100,000 \mathrm{gal} / \mathrm{d}$, and may be different for protection areas within a state. Monthly, quarterly, and annually reported data from these entities were the primary source for the water withdrawal and return-flow estimates for the DRB.

The most recent water withdrawal data for the DRB were compiled by the DRBC using state agency data from 2003 and 2007 (Partnership for the Delaware Estuary, 2012). The data showed that water use varied regionally. Use in the Upper basin was $1,570 \mathrm{Mgal} / \mathrm{d}$, and use in the Lower basin was 6,710 Mgal/d. Over 45 percent of the Upper basin use was for power generation (almost evenly split between hydroelectric and thermoelectric use), 42 percent was exported to New York or New Jersey, and most of the remainder was used for

Table 2. Principal aquifers and associated well characteristics within the Delaware River Basin.

\begin{tabular}{|c|c|c|c|c|c|c|}
\hline \multirow{2}{*}{$\begin{array}{l}\text { Principal } \\
\text { aquifer }\end{array}$} & \multirow[b]{2}{*}{$\begin{array}{l}\text { Aquifer name } \\
\text { and description }\end{array}$} & \multicolumn{4}{|c|}{ Well characteristics } & \multirow[b]{2}{*}{ Remarks } \\
\hline & & \multicolumn{2}{|c|}{$\begin{array}{l}\text { Depth } \\
\text { (feet) }\end{array}$} & \multicolumn{2}{|c|}{$\begin{array}{c}\text { Yield } \\
\text { (gallons per minute) }\end{array}$} & \\
\hline \multicolumn{7}{|c|}{ Clastic rock } \\
\hline $\begin{array}{l}\text { Sandstone } \\
\text { aquifers }\end{array}$ & $\begin{array}{l}\text { Piedmont } \\
\text { clastic rocks }\end{array}$ & $100-400$ & 600 & $50-200$ & 300 & $\begin{array}{l}\text { The rocks of this stratum are mostly shale, sand- } \\
\text { stone, and conglomerates. Groundwater flow is } \\
\text { predominantly through fractures. Groundwater } \\
\text { quality is affected by urban and agricultural } \\
\text { land-use activities and the resource is heavily } \\
\text { used for domestic and public water supply. A } \\
\text { part of this area within the Delaware River Ba- } \\
\text { sin has been designated by the Delaware River } \\
\text { Basin Commission as a "Groundwater protected } \\
\text { area" to try and prevent overuse. }\end{array}$ \\
\hline \multicolumn{7}{|c|}{ Unconsolidated deposits } \\
\hline $\begin{array}{l}\text { Not a principal } \\
\text { aquifer }\end{array}$ & $\begin{array}{l}\text { Appalachian } \\
\text { Plateaus and } \\
\text { Valley and Ridge } \\
\text { glaciofluvial } \\
\text { valley-fill } \\
\text { deposits }\end{array}$ & $50-150$ & 200 & $50-200$ & 500 & $\begin{array}{l}\text { The deposits of this stratum are a heterogeneous } \\
\text { assortment of bedded clay, silt, sand, and gravel. } \\
\text { Groundwater flow is predominantly through the } \\
\text { highly permeable and porous sand and gravel } \\
\text { outwash deposits. Some of the coarser and } \\
\text { thicker deposits are the most productive aquifers } \\
\text { in the entire Delaware River Basin. The valley- } \\
\text { fill deposits are heavily used for public and } \\
\text { domestic water supply. }\end{array}$ \\
\hline
\end{tabular}


Table 3. Water withdrawal reporting thresholds for the States of Delaware, New Jersey, New York, and Pennsylvania, and the Delaware River Basin Commission.

[DRB, Delaware River Basin; gal/d, gallons per day; Mgal/m, million gallons per month]

\begin{tabular}{|c|c|c|c|}
\hline $\begin{array}{l}\text { State agency } \\
\text { or protected area }\end{array}$ & $\begin{array}{l}\text { Reporting } \\
\text { threshold } \\
\text { (gallons per } \\
\text { day) }\end{array}$ & Water source & Water withdrawal reporting criteria \\
\hline \multicolumn{4}{|c|}{ Delaware } \\
\hline $\begin{array}{l}\text { Delaware Department of Natural Re- } \\
\text { sources and Environmental Control } \\
\text { (DNREC) Division of Water, Water } \\
\text { Supply Section, Water Allocation } \\
\text { Branch }\end{array}$ & 50,000 & $\begin{array}{l}\text { Surface water and } \\
\text { groundwater }\end{array}$ & $\begin{array}{l}\text { The } 50,000 \text { gal/d threshold applies to withdrawals on any } \\
\text { one day. Public, industrial, and golf courses (commer- } \\
\text { cial) facilities report monthly production annually for } \\
\text { each well or intake. Irrigators report March through } \\
\text { November. }\end{array}$ \\
\hline \multicolumn{4}{|c|}{ New Jersey } \\
\hline \multirow[t]{2}{*}{$\begin{array}{l}\text { New Jersey Department of Environmen- } \\
\text { tal Protection, Bureau of Water Alloca- } \\
\text { tion \& Well Permitting }\end{array}$} & 100,000 & $\begin{array}{l}\text { Surface water and } \\
\text { groundwater }\end{array}$ & $\begin{array}{l}\text { A Water Allocation Permit is required for the diversion of } \\
\text { groundwater or surface water in excess of } 100,000 \mathrm{gal} / \mathrm{d} \\
\text { for a period of more than } 30 \text { days in a } 365 \text {-consecutive- } \\
\text { day period, for purposes other than agriculture, aquacul- } \\
\text { ture or horticulture. This includes water diversions for } \\
\text { public water supply, industrial processing and cooling, } \\
\text { irrigation, sand and gravel operations, remediation, } \\
\text { power generation, and other uses. The monthly average } \\
\text { has to exceed 3.1 Mgal/month for any purpose. }\end{array}$ \\
\hline & 100,000 & $\begin{array}{l}\text { Surface water and } \\
\text { groundwater }\end{array}$ & $\begin{array}{l}\text { A Water Use Registration is required for any person with } \\
\text { the capability to divert in excess of } 100,000 \mathrm{gal} / \mathrm{d} \text { of } \\
\text { water, but who diverts less than this quantity. }\end{array}$ \\
\hline New Jersey Highlands Preservation Area & 50,000 & $\begin{array}{l}\text { Surface water and } \\
\text { groundwater }\end{array}$ & $\begin{array}{l}\text { If the monthly average exceeds } 1.55 \mathrm{Mgal} / \mathrm{m} \text { (30-day } \\
\text { average), a water allocation permit is needed. }\end{array}$ \\
\hline \multicolumn{4}{|c|}{ New York } \\
\hline $\begin{array}{l}\text { New York Department of Environmen- } \\
\text { tal Conservation (DEC), Division } \\
\text { of Water, Bureau of Water Resource } \\
\text { Management }\end{array}$ & 100,000 & $\begin{array}{l}\text { Surface water and } \\
\text { groundwater }\end{array}$ & $\begin{array}{l}\text { Entities capable of withdrawing more than } 100,000 \mathrm{gal} / \mathrm{d} \\
\text { for any purpose must report use data to DEC. Annual } \\
\text { reports must include } 12 \text { months of data, the amount of } \\
\text { water withdrawn, including the daily average for each } \\
\text { month and the peak (maximum) day amount for each } \\
\text { month. }\end{array}$ \\
\hline
\end{tabular}

drinking water. In the Lower basin, over 75 percent of the use was for thermoelectric use, with most of the remainder used for drinking water or industrial supply. Nearly 90 percent of potable use for residential and commercial purposes was through public water-supply systems; only 10 percent was from domestic wells.

Water withdrawal, interbasin transfers, return flow, and hydroelectric power release data were compiled for 11 water use categories by hydrologic subregion, basin, subbasin, and subwatershed (fig. 5). Data availability varied by state (table 4). Site-specific data were used whenever possible to estimate public supply, irrigation (golf courses, nurseries, sod farms, and crops), aquaculture, self-supplied industrial, commercial, mining, thermoelectric, and hydroelectric power withdrawals. Where site-specific data were not available, primarily for irrigation, livestock, and domestic use, various techniques, described below, were used.

\section{Site-Specific Water Use Data}

Site-specific data were compiled from a comprehensive list of facilities from respective National and state water agencies and the DRBC (table 4). Groundwater and surfacewater withdrawal and aquifer storage and recovery records, and public-supplier monthly operating reports (MORs) 
Table 3. Water withdrawal reporting thresholds for the States of Delaware, New Jersey, New York, and Pennsylvania, and the Delaware River Basin Commission.-Continued

[DRB, Delaware River Basin; gal/d, gallons per day; Mgal/m, million gallons per month]

\begin{tabular}{|c|c|c|c|}
\hline State agency & $\begin{array}{c}\text { Reporting } \\
\text { threshold } \\
\text { (gallons per } \\
\text { day) }\end{array}$ & Water source & Water withdrawal reporting criteria \\
\hline \multicolumn{4}{|c|}{ Pennsylvania } \\
\hline $\begin{array}{l}\text { Pennsylvania Department of Environmental } \\
\text { Protection, Office of Water Management }\end{array}$ & 10,000 & $\begin{array}{c}\text { Surface water } \\
\text { and } \\
\text { groundwater }\end{array}$ & $\begin{array}{l}\text { All public suppliers and hydropower facilities must register } \\
\text { their groundwater and surface-water sources and use. } \\
\text { Any person (entity) whose total withdrawal from one or } \\
\text { more points of withdrawal within a watershed operated } \\
\text { as a system either concurrently or sequentially exceeds } \\
\text { an average rate of } 10,000 \text { gallons per day in any } 30 \text {-day } \\
\text { period must register. Any person (entity) who receives } \\
\text { through interconnection an average of } 100,000 \text { gallons a } \\
\text { day in any } 30 \text {-day period must also register. }\end{array}$ \\
\hline Delaware River Basin Commission & 100,000 & $\begin{array}{l}\text { Surface water } \\
\text { and } \\
\text { groundwater }\end{array}$ & $\begin{array}{l}\text { Each person, firm, corporation, or other entity whose } \\
\text { cumulative daily average withdrawal(s) from the surface } \\
\text { or groundwaters of the DRB from any surface-water } \\
\text { intake, spring, or well, or any combination of surface- } \\
\text { water intakes, springs, or wells operated as a system, } \\
\text { exceeds } 100,000 \text { gallons per day during any } 30 \text {-day } \\
\text { period shall meter or measure and record their withdraw- } \\
\text { als and report such withdrawals to the designated agency } \\
\text { (Delaware River Basin Compact, } 32 \text { P.S. } \S 815.101 \text { et } \\
\text { seq., } 1961 \text {. Project review triggered by withdrawals of } \\
100,000 \text { gal/d or more of groundwater or surface water.) }\end{array}$ \\
\hline
\end{tabular}

were the basis for the 2010 water withdrawal estimates. State water agencies and the U.S. Environmental Protection Agency (EPA) Enforcement and Compliance History Online (ECHO) database were the source for wastewater return flows. To ensure that the reported amounts were compiled for the geographical area in which a water use transaction occurred, the county, subbasin, and subwatershed locations of the water plants, surface-water intakes and outfalls, wells, or well fields were verified using the USGS WBD (U.S. Geological Survey and U.S. Department of Agriculture, National Resources Conservation Service, 2012) and Geographic Information System (GIS) techniques. Reported quarterly, monthly or annual water withdrawal and return-flow records for 6,385 unique sites (including six interbasin transfers) were reviewed for consistency, reasonableness, and completeness (fig. 6).

There were 5,614 withdrawal sites, 765 return-flow sites, and 6 interbasin transfer sites. Of the withdrawal sites, 42 percent (2,348 sites) were in the Drinking Water sector; 38 percent (2,128 sites) were in the Agricultural sector; 19 percent (1,078 sites) were in the Industrial sector; and the remaining 1 percent (60 sites) were in the Power Generation sector. Groundwater withdrawal sites accounted for 72 percent $(4,580$ sites $)$ of the total number of sites, surfacewater withdrawal sites accounted for 16 percent (1,034 sites), return-flow sites accounted for 12 percent (765 sites), and interbasin transfer sites accounted for less than 1 percent 


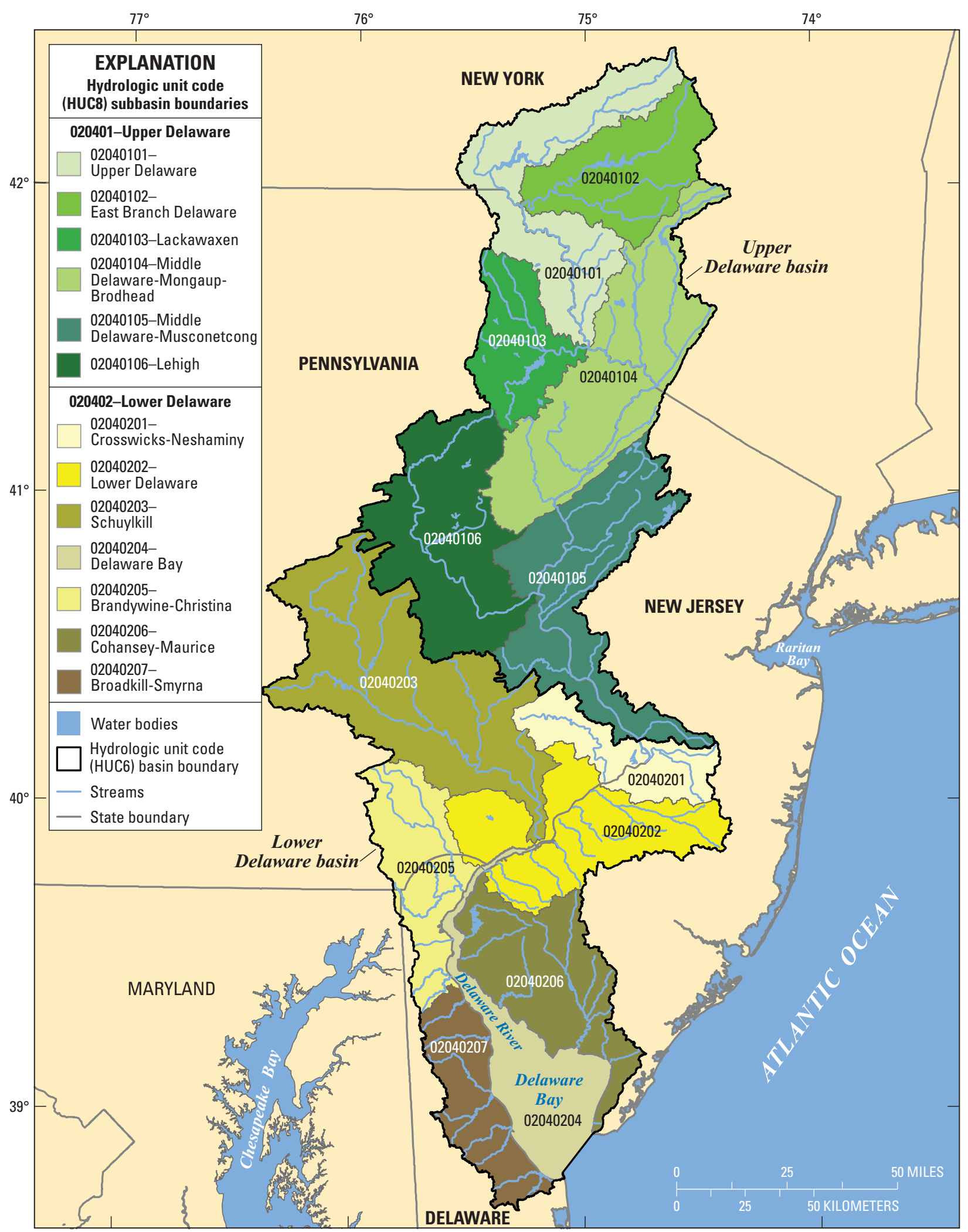

State boundaries from U.S. Geological Survey, 1983.

HUC8 and HUC6 boundaries from U.S. Geological Survey, 1984.

Water features from U.S. National Atlas, 2014.

Albers Equal-Area Conic Projection.

Figure 5. Basins and subbasins in the Delaware River Basin. 
Table 4. Summary of data sources by category and type of data, Delaware River Basin, 2010.

[DNREC, Delaware Department of Natural Resources and Environmental Control Division of Water, Water Supply Section, Water Allocation Branch; NJDEP, New Jersey Department of Environmental Protection Bureau of Water Allocation \& Well Permitting; NYSDEC, New York State Department of Environmental Conservation, Division of Water, Bureau of Water Resource Management; PADEP, Pennsylvania Department of Environmental Protection, Office of Water Management; DRBC, Delaware River Basin Commission; USGS, U.S. Geological Survey (Diehl and others, 2013); EPA, U.S. Environmental Protection Agency; ODRM, Office of the Delaware River Master; USGS-NACP, USGS North Atlantic Coastal Plain model; USDA-NASS, U.S. Department of Agriculture-National Agricultural Statistics Service; USDA-CDL, U.S. Department of Agriculture-Cropland Data Layer]

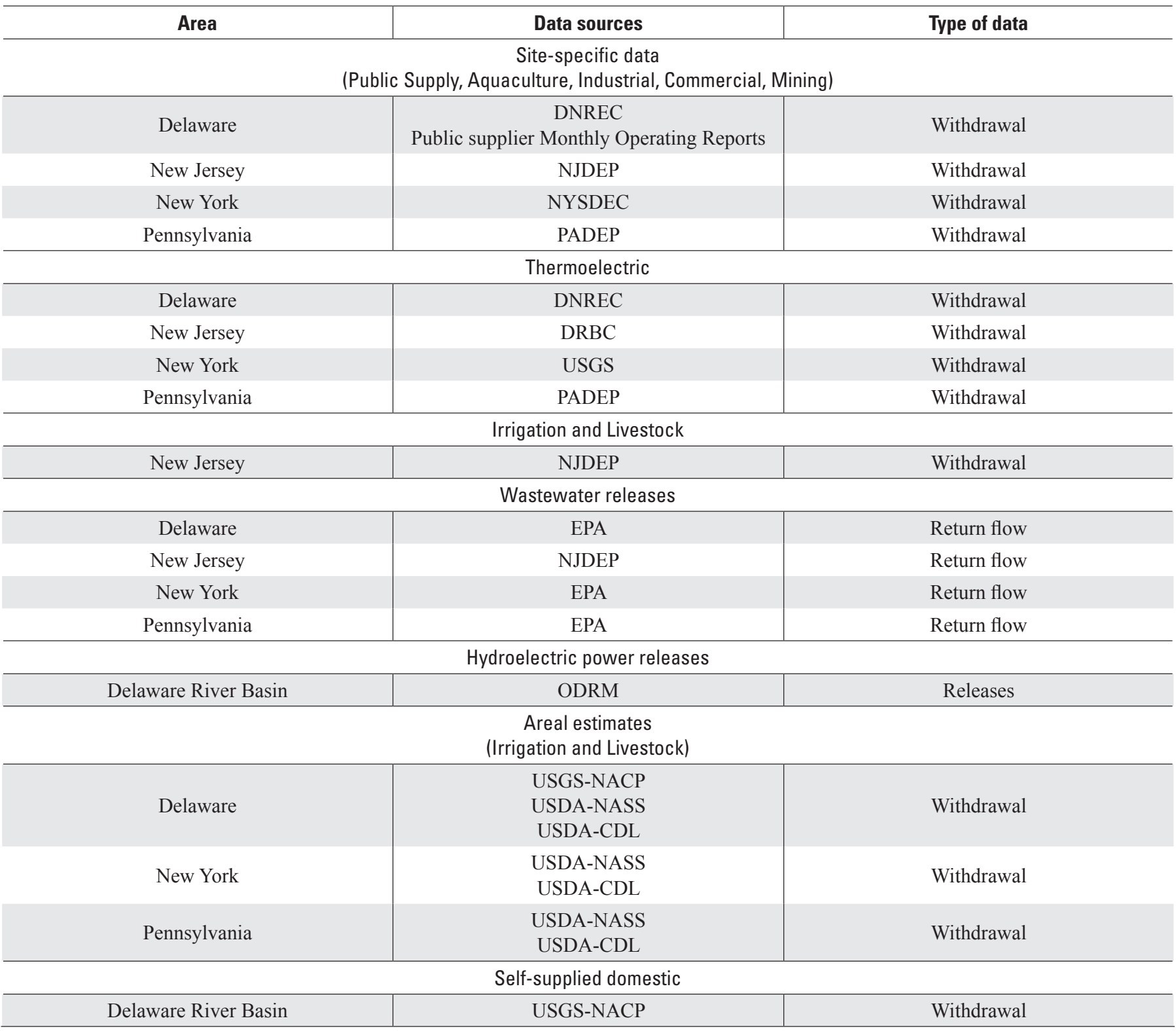

(6 sites). Site-specific water use for the aquaculture, commercial, hydroelectric power, industrial, irrigation (only New Jersey for crop irrigation; all states for golf course irrigation), mining, and thermoelectric power categories were summed by subregion, basin, subbasin, and subwatershed. Public supply required an additional accounting of water transfers to estimate water use as described in the following section. All site-specific data were assigned to hydrologic units based on site location information.

\section{Public Supply}

Public supply refers to water withdrawn by public and private water suppliers that provide water to at least 25 people or have a minimum of 15 connections. Public supply includes water delivered for domestic, commercial, industrial, other public use purposes, and system losses. Public supply numbers in this report do not differentiate between these uses. For this report, public supply and self-supplied domestic are referred 

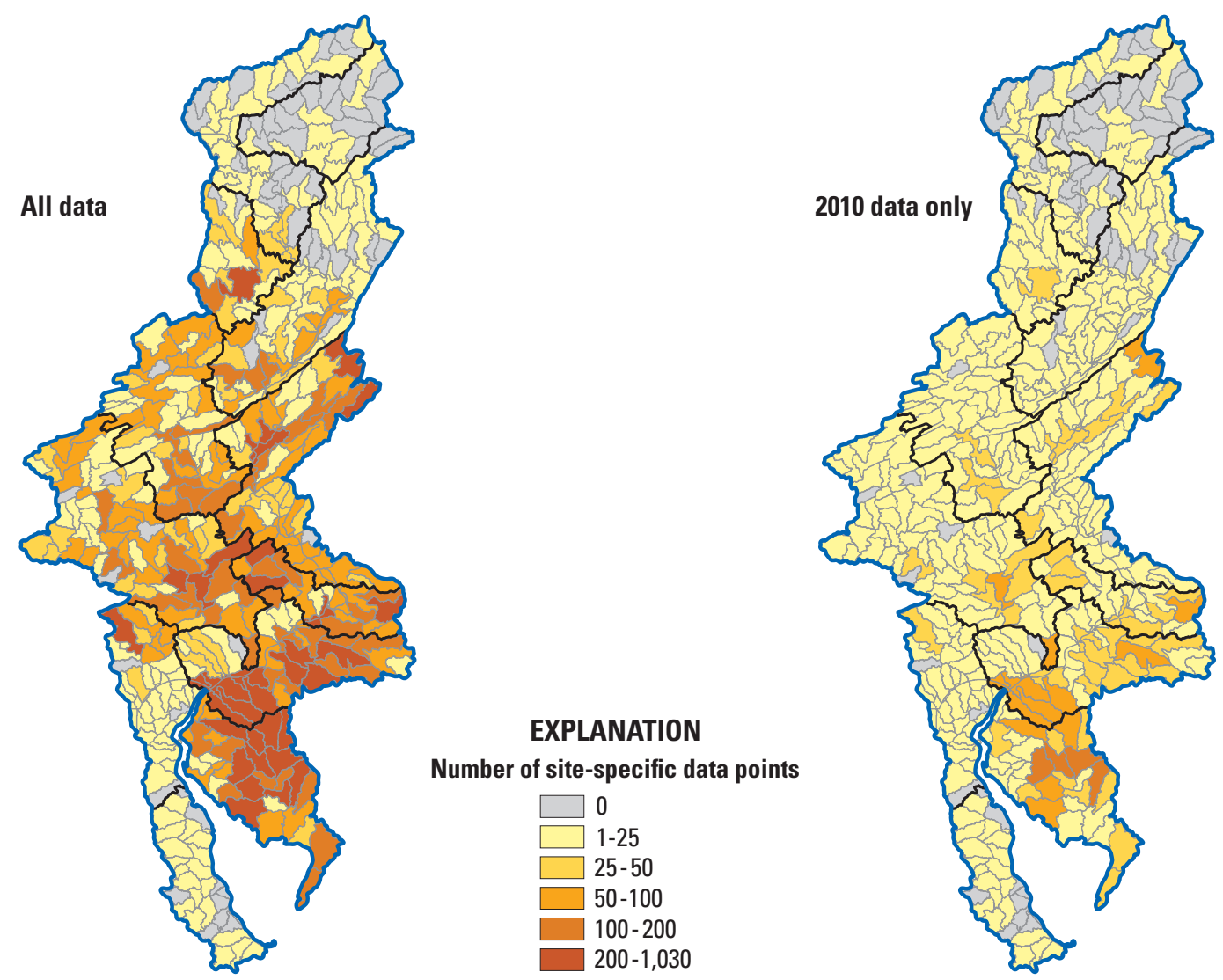

Figure 6. Number of site-specific data points by year range and subwatershed in the Delaware River Basin, 2010.

to together as potable water. For this report, the terms public supply withdrawals, public supply interbasin transfers (public supply transfers), and public supply water use each have a distinct meaning (although the terms water withdrawals and water use are commonly interchanged). A public supply withdrawal refers to water that is removed from a watershed for a beneficial purpose (offstream water use) and includes both within-basin uses and interbasin transfers; an interbasin transfer refers to water that moves into or out of the DRB; and public supply water use refers only to water used within the DRB.

Public suppliers in the DRB depend on reservoirs, surface-water intakes, single or multiple wells, and watersystem interconnections to manage water supply and meet water demand. A large amount of water is transferred from the Cannonsville, Pepacton, and Neversink Reservoirs in the Upper DRB through a series of connecting tunnels and reservoirs to the Hudson River Basin. Nearly all of the water is delivered to New York City for public supply, although some is used as a water source for nearby communities in the Hudson River Basin. The maximum reservoir releases and transfers to New York City are controlled by a Supreme Court decree (U.S. Geological Survey, 2014a) and the daily releases are maintained by the Office of the Delaware River Master
(U.S. Geological Survey, 2014c). Water is also transferred from the DRB to the Raritan River watershed for public supply use through the Delaware and Raritan Canal (D \& R Canal). Transfers are monitored at the D \& R Canal gage site at Port Mercer, New Jersey (U.S. Geological Survey, 2013). Water from the canal augments flows to either the Raritan or Millstone Rivers depending on low flow conditions to maintain minimum flow. There is a public supply transfer from the Susquehanna River Basin to the DRB through a piped distribution system into the Brandywine Creek-Christina subbasin in Pennsylvania. The transfer amounts are reported to the Pennsylvania Department of Environmental Protection.

To a lesser extent, some Burlington County and Camden County (New Jersey) (fig. 7) public supply systems periodically augmented the natural groundwater supply through artificial aquifer recharge. In 2010, excess water that had been stored in aquifers during wet periods or periods of low demand was recovered during dry periods or periods of high demand. Also, water stored in this manner can be withdrawn to be used later in months when an allocation limit is reached early in the month due to high demand. For this report, aquifer recovery numbers are reported as public supply withdrawals, and the storage values are reported as return flow. 


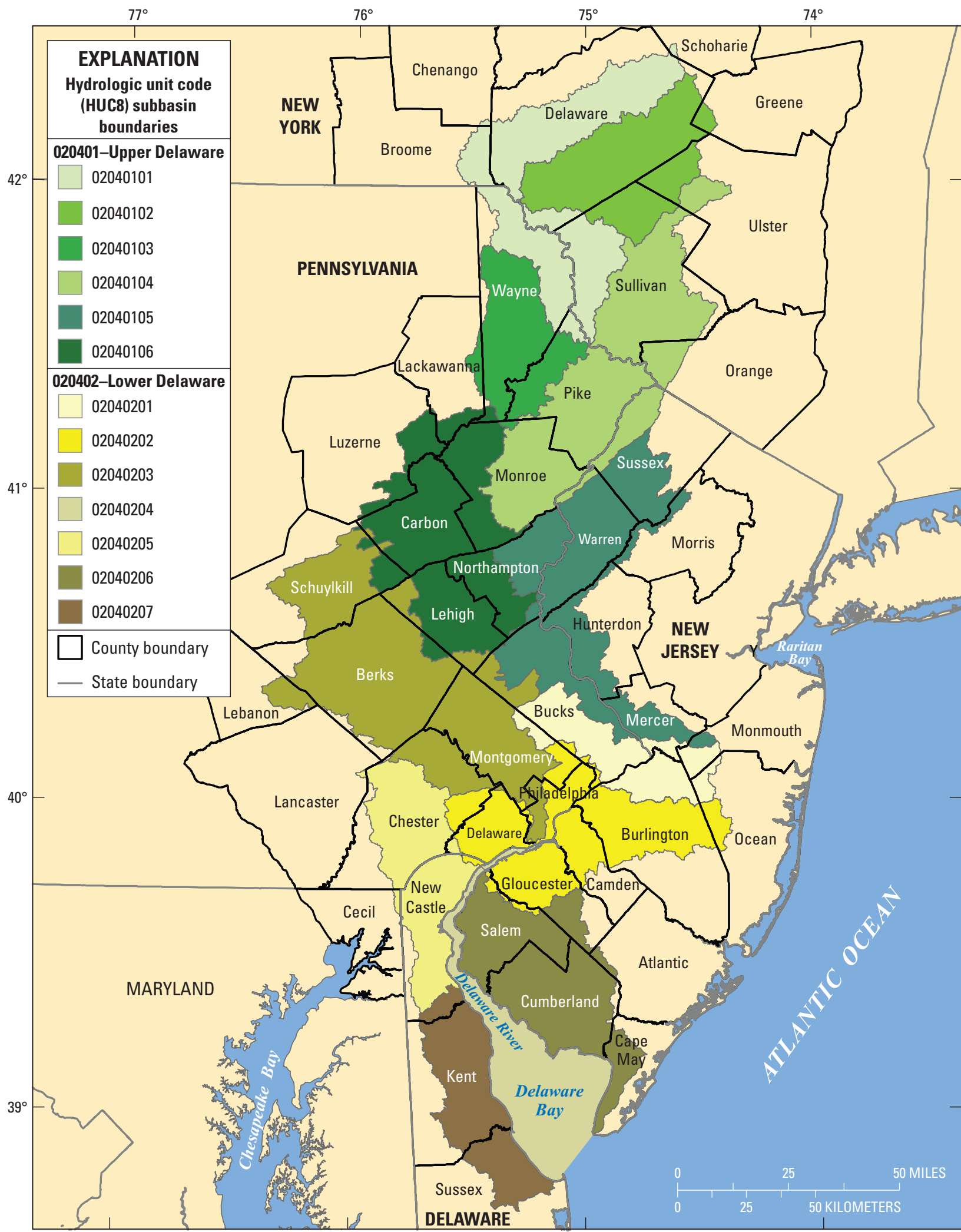

State and County boundaries from U.S. Geological Survey, 1983. HUC8 boundaries from U.S. Geological Survey, 1984. Albers Equal-Area Conic Projection.

Figure 7. Counties in the Delaware River Basin. 


\section{Areal Estimates}

Where site-specific data were not available it was necessary to develop areal estimates. Estimates of the total population and self-supplied domestic water use were developed for the entire DRB. Estimates of irrigation and livestock water use were made in states that did not have site-specific data. The different datasets and methods used to develop areal estimates, and techniques used to distribute these estimates across subbasins and subwatersheds, are described in the following sections. Areal estimates shown as a percentage of the total estimated withdrawals for each subwatershed are shown in figure 8, highlighting the impact of areal estimates in certain areas of the DRB.

\section{Total Population}

The 2010 estimates of total population were derived from 2010 census block-level data (U.S. Census Bureau, 2014). Census block population estimates were aggregated to the appropriate geographic unit based on the location of the centroid of the census block.

\section{Self-Supplied Domestic Withdrawals}

Domestic water use takes into account indoor and outdoor uses at residences. Self-supplied domestic water is usually withdrawn from a private source, such as a well. Although there may be some surface water used in the DRB for domestic supply, it is unlikely to be a significant quantity. For this reason, it was assumed for this report that only groundwater is used for domestic supply. Withdrawals were estimated basinwide as described below.

To develop current self-supplied domestic-use estimates for the DRB, information from the U.S. Census Bureau (USCB) was combined with information from the USGS National Water Information System (NWIS). USCB data used in this study include population and housing unit counts at the block group and block levels (the smallest geographical units available) from 1990, 2000, and 2010. The 1990 census included information at the block group level pertaining to the source of water supplied to housing units. This information was not collected in subsequent years. NWIS data used for this analysis were countywide estimates of total population served from a public supply source. These data are collected every 5 years, and data from 1990, 2000, and 2005 was used for this analysis.

For 1990, the total housing units within a block group, and the amount under public supply, were estimated so the percentage of housing units on public supply could be calculated for all block groups. For any given county, these block groups were then ranked and summed (from largest percentage to smallest), until the total population on public supply matched the NWIS estimate. The percentage of public supply housing units where the NWIS and USCB public supply totals

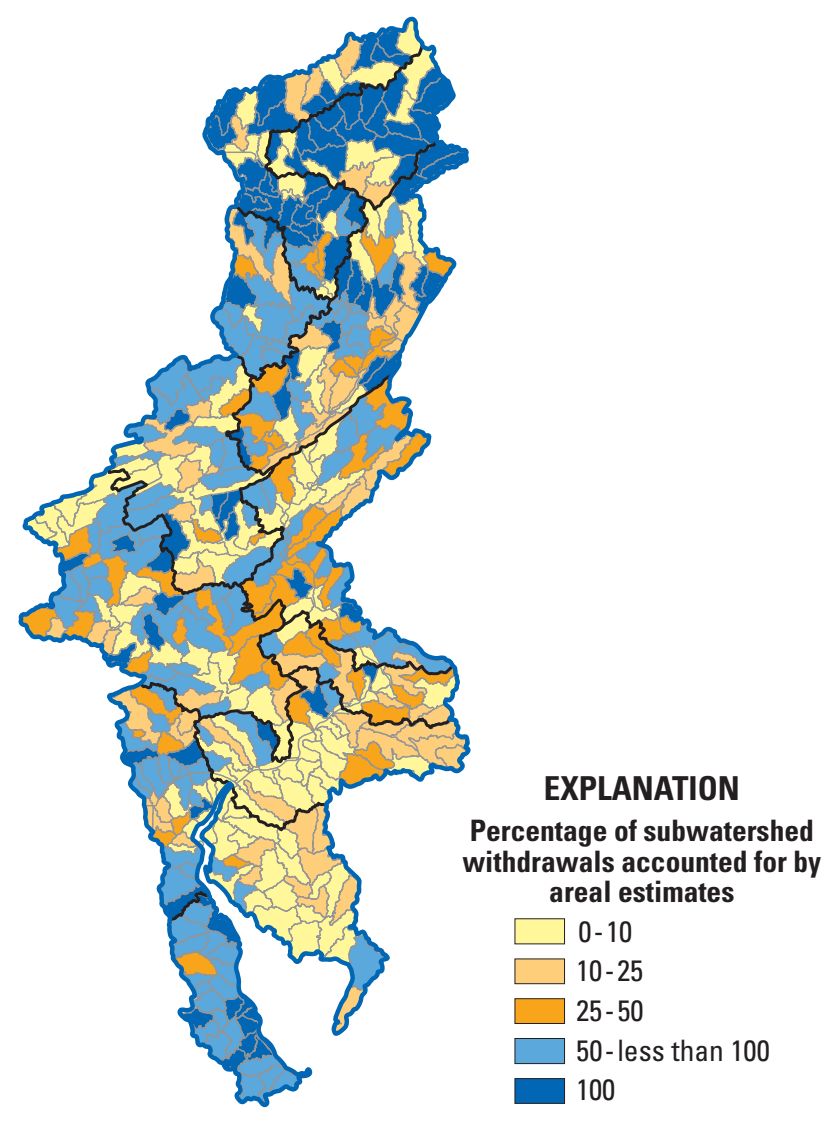

Figure 8. Percentage of subwatershed withdrawals accounted for by areal estimates in the Delaware River Basin, 2010.

most closely matched was then set as a cut-off value for each county. Any block group with a percentage of housing units above the cut-off value was considered fully public supply, whereas all those less than the cut-off value were considered to be self-supplied domestic.

Preliminary countywide estimates for 2000 and 2010 using the above technique did not always match NWIS values. Analysis of the data showed a trend for many counties where block groups with a high population total (and population density) were falling below the cut-off value, thus labelling them as domestic self-supply zones. In reality, they were likely to be publicly supplied. To address this issue, a 5-percent margin of error for population density (people per square mile) was applied to each county. The 95th percentile of population density was calculated for block groups that fall under the cut-off value, and a second condition was set in place. Block groups that were below the cut-off, but exceeded the 95th percentile of population density, were flipped from being characterized as domestic self-supply to public supply. Once this correction was applied, matches with NWIS county data were much improved. 
The distribution of public supply and self-supplied populations by census block as determined through the above process is shown in figure 9. Results from this method were visually compared to existing data layers containing service area boundaries for public supply systems as a QA/QC check. This method of classifying census blocks was selected to be used for this study since it could be applied to other areas throughout the Nation where public supply system service area boundaries are not available.

Self-supplied populations in the DRB for 2000 and 2010 were estimated using the techniques described above. A coefficient of 75 gallons per person per day (the 2005 average selfsupplied domestic per capita for the four states) (Kenny and others, 2009) was applied to the self-supplied population to estimate self-supplied domestic withdrawals. Centroids of the census blocks were matched to 8-digit subbasin and 12-digit subwatershed boundaries and summed using GIS to calculate water use in a watershed.

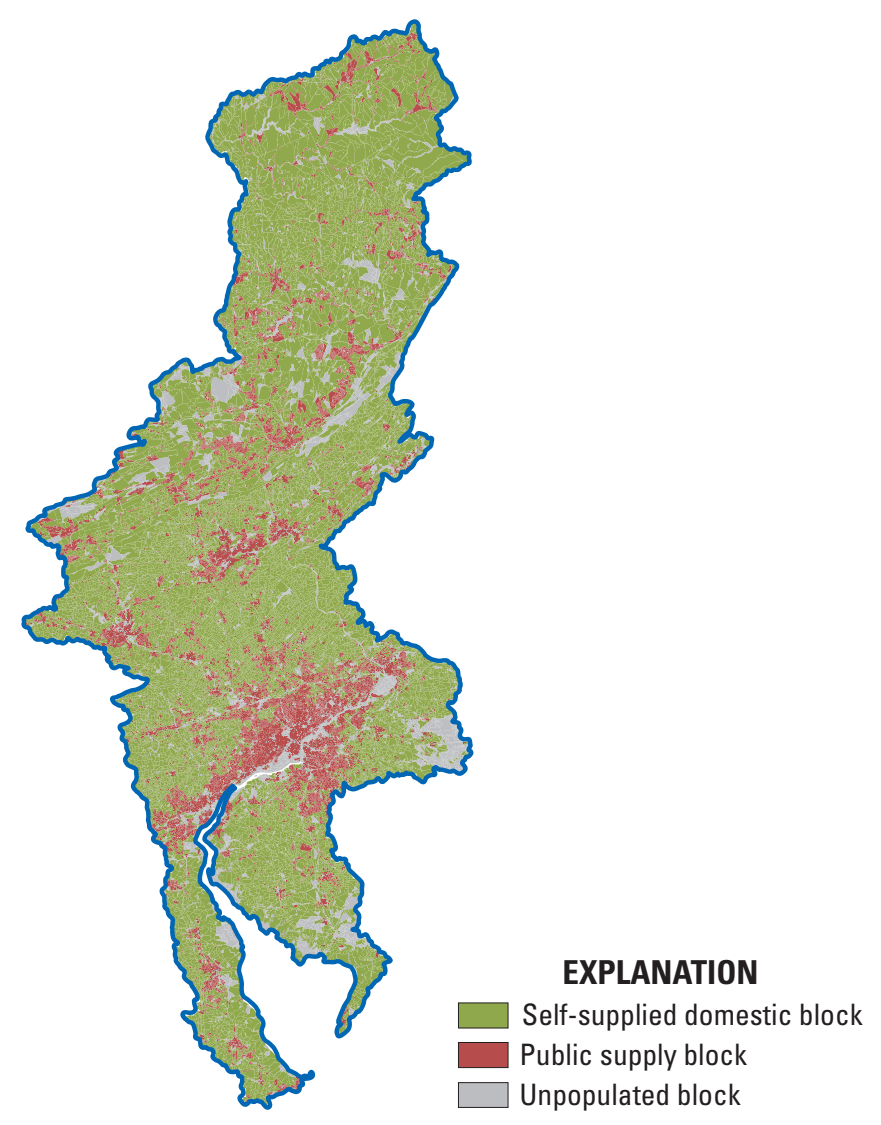

Figure 9. Distribution of public supply and self-supplied domestic census blocks in the Delaware River Basin, 2010.

\section{Irrigation}

Irrigation water use includes water that is applied by an irrigation system to sustain plant growth in all agricultural and horticultural practices. Golf course, park, nursery, turf farm, cemetery, and other self-supplied landscape-watering uses were also included. A mix of site-specific and areal estimates was used to estimate total irrigation in the DRB. Site-specific irrigation withdrawal data were available for golf courses, nurseries, and turf farms for all states. Site-specific data for crop irrigation was available for New Jersey. Areal irrigation estimates were made for Delaware, New York, and Pennsylvania by combining the 2010 NWIS county crop irrigation data (U.S Geological Survey, 2014c) for these three states with the 2010 U.S. Department of Agriculture (USDA) Cropland Data Layer (CDL) (U.S. Department of Agriculture, National Agricultural Statistics Service, 2010). For Delaware, a point dataset was available for center-pivot irrigation systems and was used to refine county crop irrigation estimates for that state.

To develop areal irrigation estimates, the 2010 NWIS county crop irrigation data were applied to selected CDL areas. Urban areas, water bodies and wetlands, forested areas, barren areas, pasture and grass, other hay, clover, and wildflowers were excluded as areas of potential irrigation in a county, and any remaining area was considered to be irrigated land. Total countywide irrigation withdrawals from NWIS by groundwater and surface water were distributed equally across the selected CDL crop types for that county. These values were then matched with 8-digit subbasin and 12-digit subwatershed boundaries using GIS and summed to calculate water use in a selected geographical area.

\section{Livestock}

Livestock water use is water associated with livestock watering, dairy operations, and other on-farm needs. Livestock includes dairy cows and heifers, beef cattle and calves, sheep and lambs, goats, hogs and pigs, horses, and poultry. Other livestock water uses include cooling of facilities for the animals and animal products such as milk, dairy sanitation and wash down of facilities, animal waste-disposal systems, and incidental water losses. Total livestock withdrawals relied on site-specific data for New Jersey, and areal estimates for the remaining states were made by combining the 2010 NWIS county estimates (U.S Geological Survey, 2014c; Lovelace, 2009 ) with the 2010 CDL data layers (U.S. Department of Agriculture, National Agricultural Statistics Service, 2010).

To develop areal livestock estimates, the 2010 NWIS county livestock use data were applied to selected CDL areas. Areas labeled as pasture, grass, or other hay were identified as areas of potential livestock watering and (or) livestock operations in a county. Total livestock withdrawals from NWIS by groundwater and surface water were then distributed equally across these identified areas. These values were then matched with 8-digit subbasin and 12-digit subwatershed boundaries using GIS and summed to calculate water use in a selected geographical area. 


\section{Water Use}

Water can be withdrawn from rivers, reservoirs, and aquifers to meet offstream needs for public supply, self-supplied residential, irrigation, livestock, aquaculture, self-supplied industrial, commercial, mining, and thermoelectric power generation purposes. Water in river and reservoir systems can be used instream for hydroelectric power generation, navigation, recreation, maintaining minimum streamflows to support fish and wildlife habitat, and for wastewater assimilation. This report presents instream and offstream water use estimates from 2010 for the DRB in Delaware, New Jersey, New York, and Pennsylvania.

\section{Total Water Withdrawals}

Total water withdrawals in the DRB for 2010 were compiled for nine categories of use: public supply, self-supplied domestic, irrigation, livestock, aquaculture, industrial, commercial, mining, and thermoelectric power generation. Total subbasin populations and withdrawals by source for 2010 are listed in table 5. Total freshwater and saline-water withdrawals were calculated to be $7,130 \mathrm{Mgal} / \mathrm{d}$, or 7,990 thousand acrefeet per year (acre-ft/yr). Freshwater withdrawals of $4,130 \mathrm{Mgal} / \mathrm{d}$ made up 58 percent of the total withdrawals, with $651 \mathrm{Mgal} / \mathrm{d}$ (9 percent of the total) being exported outside the basin to New York City (574 Mgal/d) and New Jersey (77.3 Mgal/d). Saline-water withdrawals were 3,000 Mgal/d (42 percent of the total), which were primarily brackish water from the Delaware Estuary used to cool thermoelectric powerplants. Total surface-water withdrawals were estimated to be $6,590 \mathrm{Mgal} / \mathrm{d}$, or 92 percent of the total (fig. 10); about 54 percent $(3,590 \mathrm{Mgal} / \mathrm{d})$ of surface water withdrawn was freshwater. Total groundwater withdrawals were calculated to be about 8 percent of the total $(545 \mathrm{Mgal} / \mathrm{d})$, all of which was freshwater. The geographic distribution of total, surface-water, and groundwater withdrawals in the DRB is shown by subbasin in figure 11 and by subwatershed in figure 11a.

Withdrawals are generally highest in the southern half of the basin, where most of the population lives, but they can also be high in the north due to out-of-basin transfers. Withdrawals in New Jersey (3,930 Mgal/d) and Pennsylvania (2,120 Mgal/d) accounted for 85 percent of total withdrawals and were dominated by withdrawals for thermoelectric power generation. Withdrawals in New York (609 Mgal/d) and Delaware $(475 \mathrm{Mgal} / \mathrm{d})$ each accounted for less than 10 percent of total withdrawals. Ninety-four percent of the water withdrawals in New York are transferred out of the basin to supply New York City with drinking water.

The distribution of water withdrawals by category when withdrawals for thermoelectric power generation uses are not considered is shown in figure 10c. In this case, withdrawals for public supply uses within the DRB (840 Mgal/d) and transfers outside of the DRB (651 Mgal/d) account for 68 percent of the total. The distribution of water withdrawals by water use category and state (excluding withdrawals for thermoelectric power generation and transfers out of the DRB) is also shown in figure 10c.

In this report, discussion of results is done by grouping water use categories into sectors of water use (table 6). The Power Generation sector $(4,910 \mathrm{Mgal} / \mathrm{d}$; 69 percent of total withdrawals) includes the categories of thermoelectric power generation (an offstream water use) and hydroelectric power generation (an instream water use). The Drinking Water sector $(1,610 \mathrm{Mgal} / \mathrm{d} ; 23$ percent of total withdrawals) includes public supply and self-supplied domestic uses. The Industrial sector (408 Mgal/d; less than 6 percent of total withdrawals) includes self-supplied industrial, commercial, and mining uses. The Agricultural sector (201 Mgal/d; less than 3 percent of total withdrawals) includes irrigation, livestock, and aquaculture uses. Data on total withdrawals by sector and subwatershed were calculated, and the sector with the largest water withdrawals for each subwatershed is shown in figure 12. Whereas withdrawals for the Drinking Water sector are distributed throughout the DRB, Power sector withdrawals are found mainly along the Delaware Estuary and the main stem and major tributaries of the Delaware River. The Agricultural sector is the largest sector in many subwatersheds in the Coastal Plain areas of Delaware and New Jersey.

Total water withdrawals by category and subbasin are listed in table 7; they are also listed by source of water in tables 8 (surface water) and 9 (groundwater). Thermoelectric power $(4,910 \mathrm{Mgal} / \mathrm{d})$ was the largest category of water use, followed by public supply (1,490 Mgal/d), self-supplied industrial (350 Mgal/d), irrigation (175 Mgal/d), and self-supplied domestic $(117 \mathrm{Mgal} / \mathrm{d})$. The remaining categories of water use - mining, aquaculture, livestock, and commercial-combined were about 1 percent $(73.2 \mathrm{Mgal} / \mathrm{d})$ of total withdrawals.

\section{Power Generation Sector}

The Power Generation sector consists of the thermoelectric power generation and hydroelectric power generation categories. Thermoelectric power generation withdrawals were considered to be offstream withdrawals and thus were included in the calculations of total withdrawals in this report. Hydroelectric power generation water withdrawals were considered to be instream withdrawals and were not included along with offstream withdrawal calculations, but they are discussed in the Instream Hydroelectric Power Water Use section.

\section{Offstream Thermoelectric Power Water Withdrawals}

Total water withdrawals in the DRB for the thermoelectric power generation category were 4,910 Mgal/d (table 10), or 5,510 thousand acre-ft/yr in 2010. About 61 percent of thermoelectric withdrawals $(2,990 \mathrm{Mgal} / \mathrm{d})$ were saline water from the estuary. Thermoelectric power generation represents 69 percent of total withdrawals, and 47 percent of all freshwater withdrawals in the DRB. Almost all of the freshwater 
Table 5. Total water withdrawals by source and subbasin, Delaware River Basin, 2010.

[Values may not sum to totals because of independent rounding.]

\begin{tabular}{|c|c|c|c|c|c|c|c|c|c|c|c|c|}
\hline \multirow{4}{*}{$\begin{array}{c}\text { Hydrologic } \\
\text { unit }\end{array}$} & \multirow{4}{*}{$\begin{array}{c}\text { Hydro- } \\
\text { logic } \\
\text { unit } \\
\text { code }\end{array}$} & \multirow{4}{*}{$\begin{array}{c}\text { Popula- } \\
\text { tion } \\
\text { (thou- } \\
\text { sands) }\end{array}$} & \multicolumn{7}{|c|}{$\begin{array}{c}\text { Withdrawals } \\
\text { (million gallons per day) }\end{array}$} & \multicolumn{3}{|c|}{$\begin{array}{c}\text { Withdrawals } \\
\text { (thousand acre-feet per } \\
\text { year) }\end{array}$} \\
\hline & & & \multicolumn{4}{|c|}{ By source and type } & \multirow{2}{*}{\multicolumn{2}{|c|}{ Total }} & \multirow{3}{*}{ Total } & \multicolumn{2}{|c|}{ By source } & \multirow{3}{*}{ Total } \\
\hline & & & $\begin{array}{c}\text { Ground- } \\
\text { water }\end{array}$ & \multicolumn{3}{|c|}{ Surface water } & & & & Ground- & Surface & \\
\hline & & & Fresh & Fresh & $\begin{array}{l}\text { Sa- } \\
\text { line }\end{array}$ & Total & Fresh & $\begin{array}{l}\text { Sa- } \\
\text { line }\end{array}$ & & water & water & \\
\hline \multicolumn{13}{|c|}{ Study Area (total) } \\
\hline & & 8,260 & 545 & 3,590 & 3,000 & 6,590 & 4,130 & 3,000 & 7,130 & 611 & 7,380 & 7,990 \\
\hline \multicolumn{13}{|c|}{ Upper Delaware River Basin (total) } \\
\hline & 020401 & 1,700 & 134 & 1,050 & $\mathbf{0}$ & 1,050 & 1,190 & $\mathbf{0}$ & 1,190 & 150 & 1,180 & 1,330 \\
\hline \multicolumn{13}{|c|}{ Upper Delaware River Subbasins } \\
\hline Lackawaxen & 02040103 & 57.1 & 4.31 & 0.72 & 0 & 0.72 & 5.03 & 0 & 5.03 & 4.83 & 0.81 & 5.64 \\
\hline $\begin{array}{l}\text { Middle } \\
\text { Delaware- } \\
\text { Mongaup- } \\
\text { Brodhead }\end{array}$ & 02040104 & 232 & 14.2 & 109 & 0 & 109 & 123 & 0 & 123 & 15.9 & 122 & 138 \\
\hline $\begin{array}{l}\text { Middle } \\
\text { Delaware- } \\
\text { Musconet- } \\
\text { cong }\end{array}$ & 02040105 & 669 & 57.8 & 400 & 0 & 400 & 458 & 0 & 458 & 64.8 & 449 & 514 \\
\hline $\begin{array}{c}\text { Lower } \\
\text { Delaware }\end{array}$ & 02040202 & 2,990 & 104 & 1,030 & 1.69 & 1,030 & 1,130 & 1.69 & 1,130 & 117 & 1,150 & 1,270 \\
\hline Schuylkill & 02040203 & 1,660 & 72.5 & 498 & 0 & 498 & 571 & 0 & 571 & 81.3 & 558 & 640 \\
\hline $\begin{array}{l}\text { Brandywine- } \\
\text { Christina }\end{array}$ & 02040205 & 754 & 37.6 & 380 & 0 & 380 & 418 & 0 & 418 & 42.2 & 426 & 469 \\
\hline $\begin{array}{l}\text { Cohansey- } \\
\text { Maurice }\end{array}$ & 02040206 & 299 & 81.8 & 50.3 & 3,000 & 3,050 & 132 & 3,000 & 3,130 & 91.7 & 3,420 & 3,510 \\
\hline $\begin{array}{l}\text { Broadkill- } \\
\text { Smyrna }\end{array}$ & 02040207 & 193 & 74.1 & 9.41 & 0 & 9.41 & 83.5 & 0 & 83.5 & 83.0 & 10.5 & 93.6 \\
\hline
\end{tabular}


$\boldsymbol{A}$

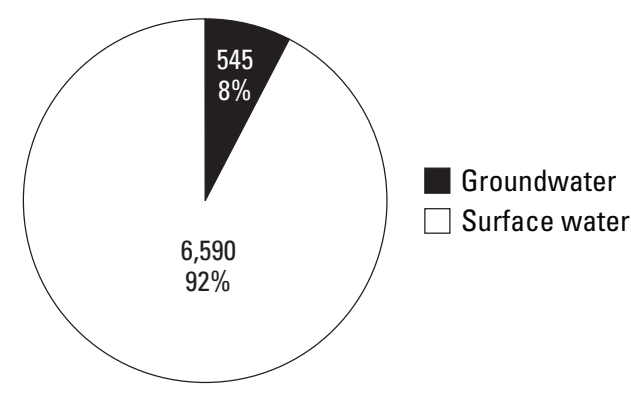

$\boldsymbol{B}$

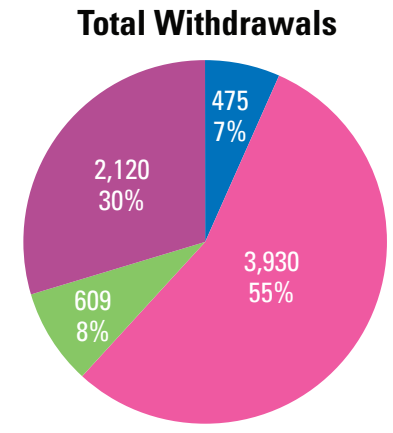

Total Withdrawals by Source
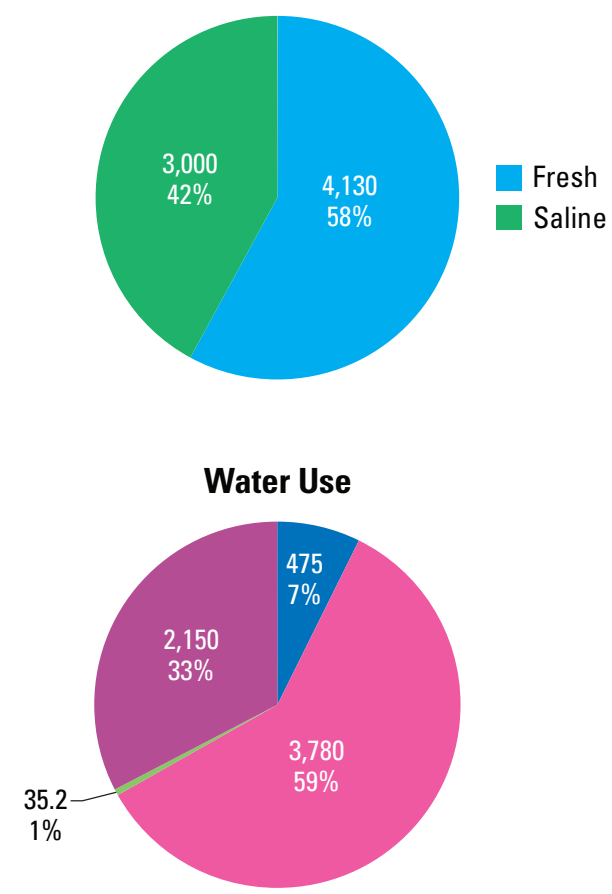

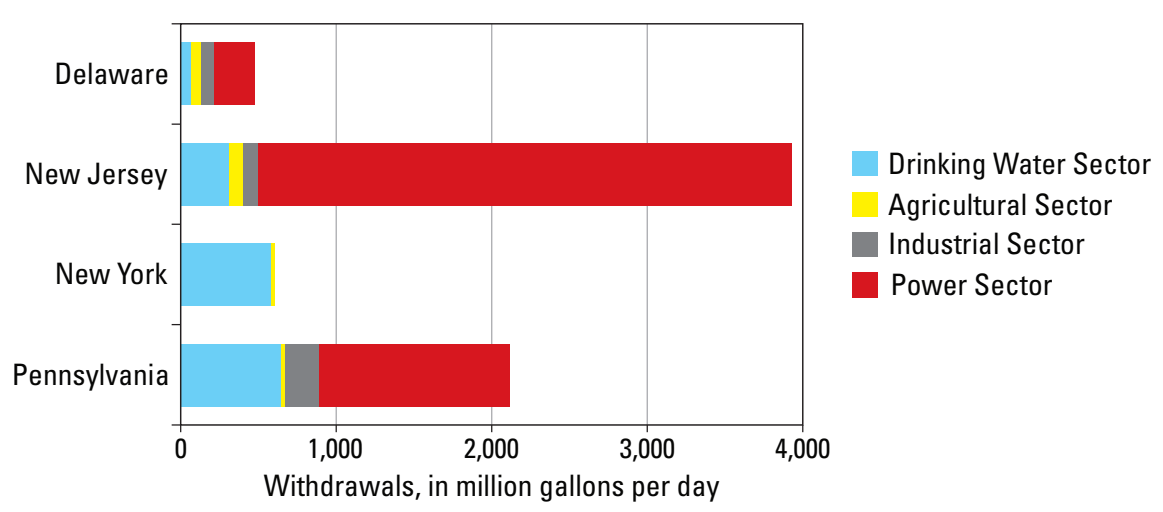

Figure 10. Distribution of total water withdrawals by $A$, source, $B$, state and sector, and $C$, water use category and state in the Delaware River Basin, 2010. $(<$, less than; \%, percent)

withdrawn $(1,920 \mathrm{Mgal} / \mathrm{d})$ for thermoelectric power generation in the DRB was from surface-water sources; less than 1 percent (3.00 Mgal/d) was from groundwater sources.

The Lower basin accounted for 95 percent $(4,650 \mathrm{Mgal} / \mathrm{d})$ of the total Power Generation sector withdrawals, whereas the Upper basin accounted for only 5 percent $(262 \mathrm{Mgal} / \mathrm{d})$ (table 11, fig. 13a). The Lower basin water withdrawals were almost all from surface-water sources $(4,650 \mathrm{Mgal} / \mathrm{d}$ of surface water, $2.65 \mathrm{Mgal} / \mathrm{d}$ of groundwater). The Lower basin water withdrawals were also 64 percent $(2,990 \mathrm{Mgal} / \mathrm{d})$ saline water from the estuary, and 36 percent $(1,660 \mathrm{Mgal} / \mathrm{d})$ freshwater. The Upper basin withdrawals were all freshwater withdrawals, and they were almost all from surface-water sources (261 Mgal/d of surface water, $0.35 \mathrm{Mgal} / \mathrm{d}$ of groundwater). The large amounts of water withdrawn for thermoelectric power generation were used primarily for once-through cooling in thermoelectric powerplants.

The geographic distribution of total thermoelectric power water withdrawals by subbasin and subwatershed is shown in figure 13b. The largest withdrawals were near urban centers, and were primarily on the largest rivers (the Delaware and the Schuylkill) and the Delaware Estuary. The subbasin with the largest water withdrawals for thermoelectric power generation (02040206) accounted for 61 percent $(2,990 \mathrm{Mgal} / \mathrm{d})$ of the 
C

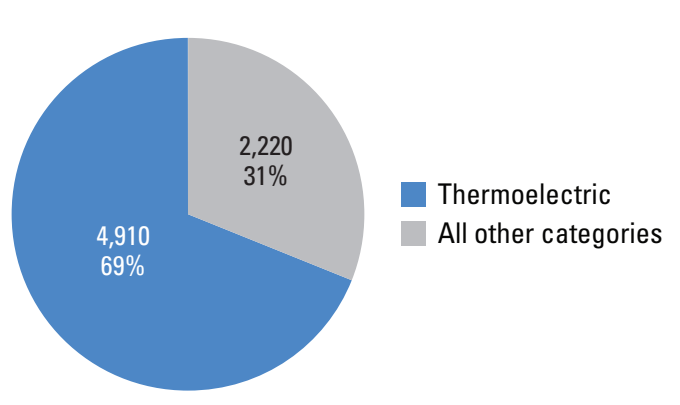

Total withdrawals by category and state

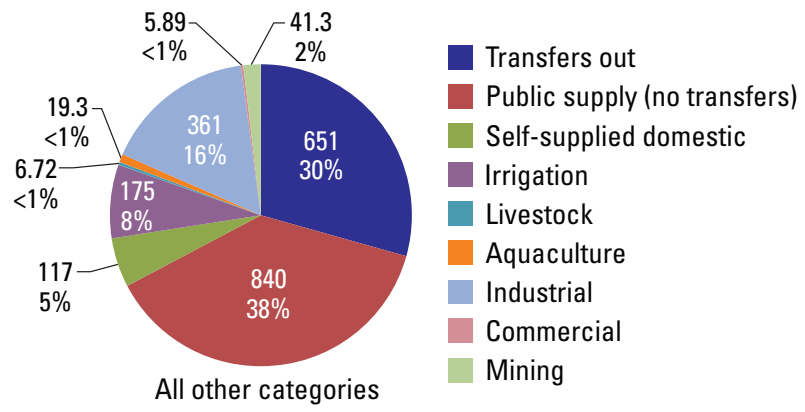

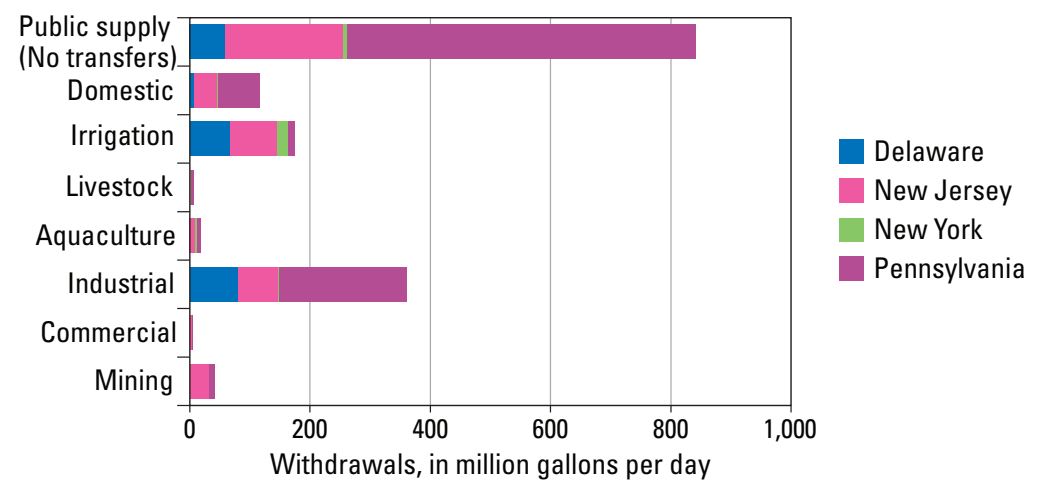

Figure 10. Distribution of total water withdrawals by $A$, source, $B$, state and sector, and $C$, water use category and state in the Delaware River Basin, 2010. (<, less than; \%, percent)—Continued

thermoelectric power generation water withdrawn in the DRB and was all saline water; most of this water was used by a single facility. The largest freshwater withdrawals were in subbasins 02040202 (706 Mgal/d) and $02040201(478 \mathrm{Mgal} / \mathrm{d})$ and accounted for 62 percent $(1,180 \mathrm{Mgal} / \mathrm{d})$ of the total freshwater withdrawals for thermoelectric power generation in the DRB. The subwatershed with the largest saline-water withdrawals $(2,980 \mathrm{Mgal} / \mathrm{d})$ was 020402060602 , where the PSEG Salem Generating Station Powerplant is located. The subwatershed with the largest freshwater withdrawals (690 Mgal/d) was 020402020601, where the Exelon Eddystone Powerplant is located.

A single subbasin (02040202) had fresh surface-water withdrawals that accounted for 37 percent $(706 \mathrm{Mgal} / \mathrm{d})$ of the total for the DRB whereas another subbasin (02040203) accounted for 76 percent $(2.28 \mathrm{Mgal} / \mathrm{d})$ of thermoelectric power generation fresh groundwater withdrawals.

Almost 64 percent $(1,220 \mathrm{Mgal} / \mathrm{d})$ of the freshwater withdrawn for thermoelectric power generation was withdrawn in Pennsylvania. Subbasin 02040202 in Pennsylvania accounted for 36 percent (690 Mgal/d) of the thermoelectric power generation freshwater withdrawn in the DRB. In New
Jersey, reported water withdrawals for thermoelectric power generation were $3,430 \mathrm{Mgal} / \mathrm{d}$ (70 percent of the total) and were mainly (87 percent, 2,990 Mgal/d) from the saline estuary. Reported withdrawals in Delaware represented 5 percent of total category withdrawals and were almost exclusively from fresh surface-water sources. No water withdrawals for thermoelectric power generation were reported for New York.

\section{Instream Hydroelectric Power Water Use}

Controlled daily releases (in cubic feet per second) for reservoirs that produce power in the DRB were reported to the Office of the Delaware River Master in 2010. The Wallenpaupack Hydroelectric Powerplant on the Lackawaxen River depends on water from Wallenpaupack Creek contained by a 1,280-ft long and 70-ft high dam (Pennsylvania Power and Light, 2014). The Mongaup River system consists of five reservoirs and three hydroelectric stations that utilize available water resources from the 210- $\mathrm{mi}^{2}$ Mongaup River Basin (Eagle Creek Renewable Energy, 2014). The amount of instream use for hydroelectric power generation purposes in 2010 was reported to be $273 \mathrm{Mgal} / \mathrm{d}$ for the Wallenpaupack plant and $127 \mathrm{Mgal} / \mathrm{d}$ for the Mongaup River system. 


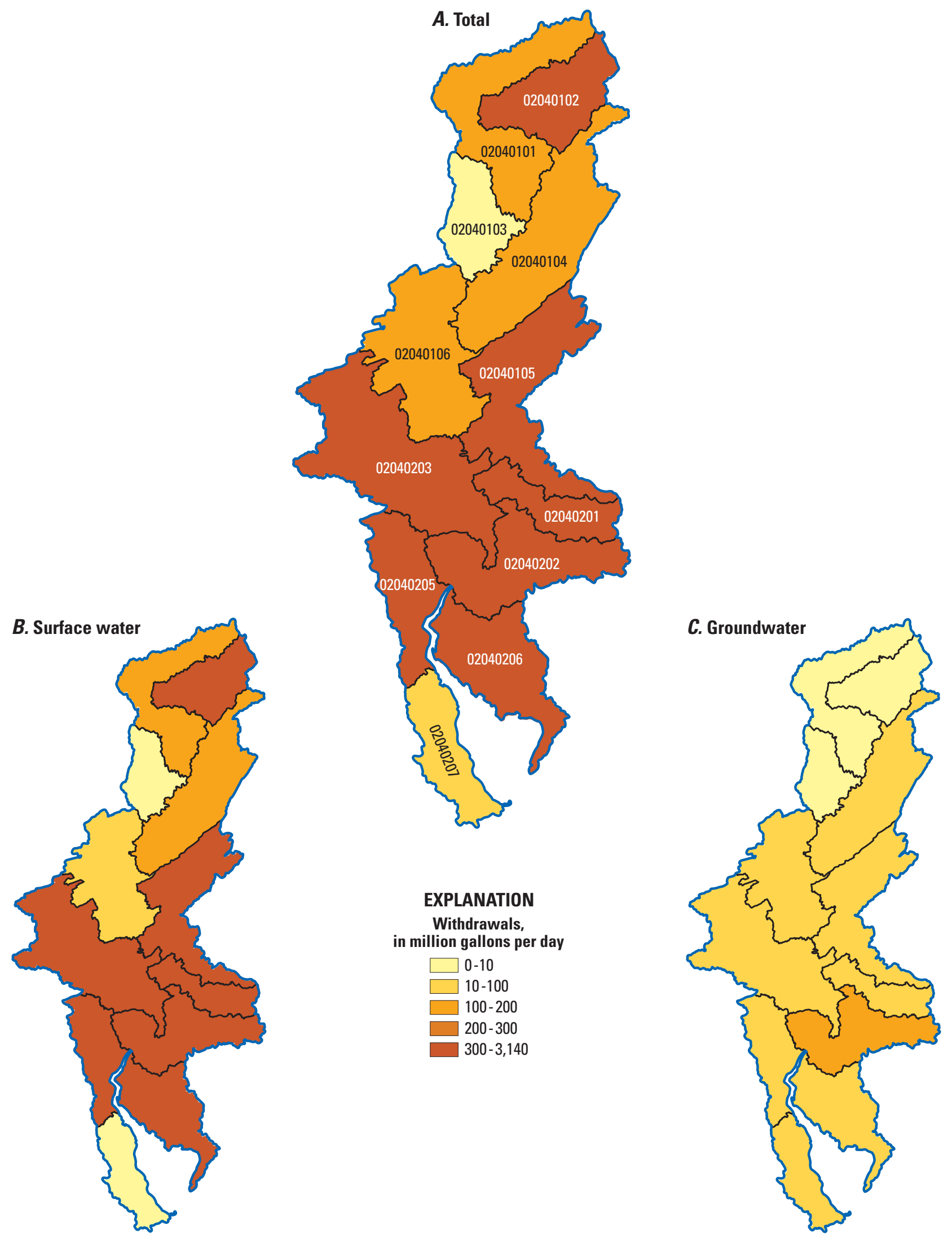

Figure 11. $A$, Total, $B$, surface-water, and $C$, groundwater withdrawals by subbasin in the Delaware River Basin, 2010. 


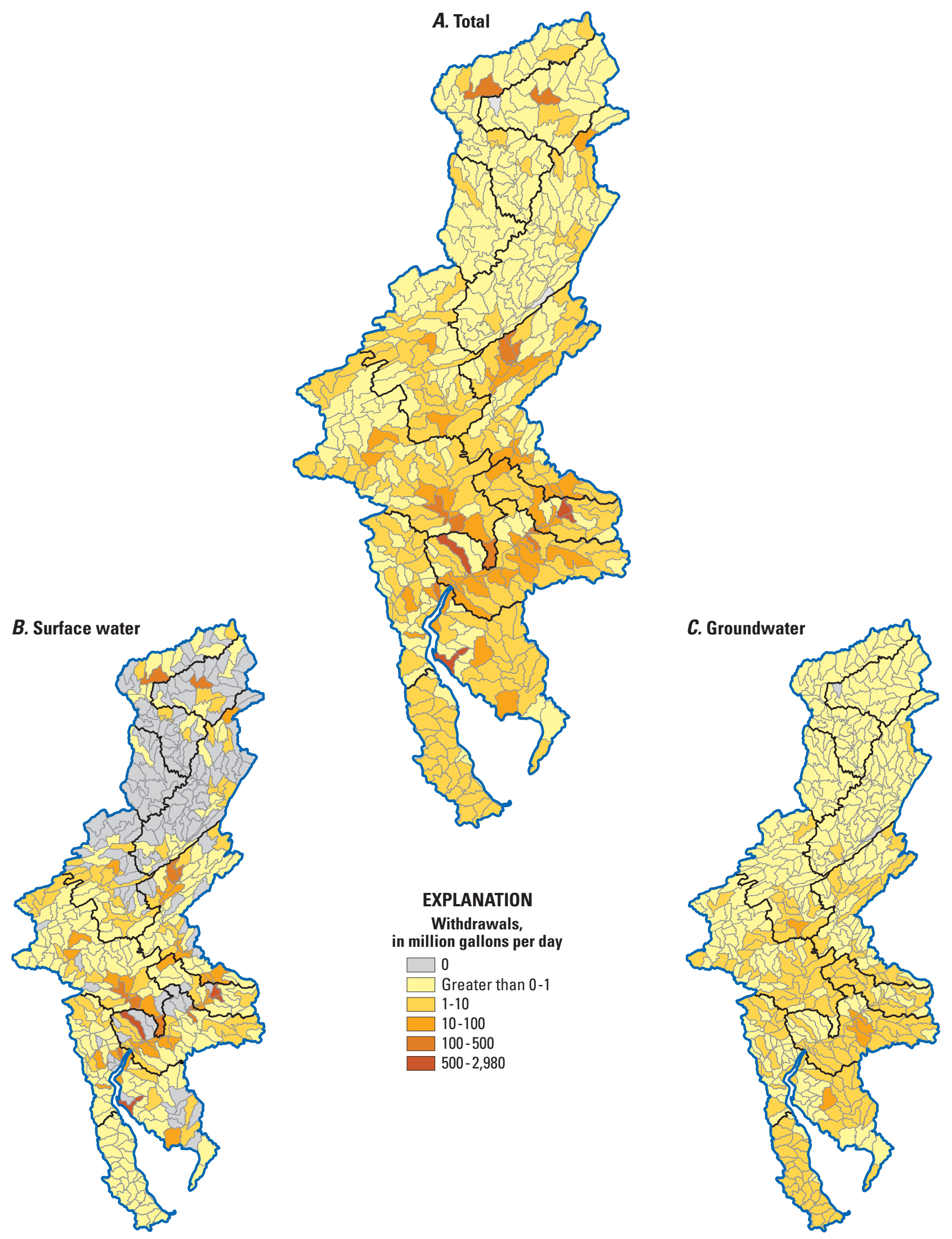

Figure 11a. $A$, Total, $B$, surface-water, and $C$, groundwater withdrawals by subwatershed in the Delaware River Basin, 2010. 
Table 6. Total water withdrawals by source and sector, Delaware River Basin, 2010.

[Values may not sum to totals because of independent rounding.]

\begin{tabular}{|c|c|c|c|c|c|c|c|c|c|c|}
\hline \multirow{4}{*}{ Sector } & \multicolumn{7}{|c|}{$\begin{array}{c}\text { Withdrawals } \\
\text { (million gallons per day) }\end{array}$} & \multicolumn{3}{|c|}{$\begin{array}{c}\text { Withdrawals } \\
\text { (thousand acre-feet per year) }\end{array}$} \\
\hline & \multicolumn{4}{|c|}{ By source and type } & \multirow{2}{*}{\multicolumn{2}{|c|}{ Total }} & \multirow{3}{*}{ Total } & \multirow{2}{*}{\multicolumn{2}{|c|}{ By source }} & \multirow{3}{*}{ Total } \\
\hline & \multirow{2}{*}{$\begin{array}{c}\begin{array}{c}\text { Ground- } \\
\text { water }\end{array} \\
\text { Fresh }\end{array}$} & \multicolumn{3}{|c|}{ Surface water } & & & & & & \\
\hline & & Fresh & Saline & Total & Fresh & Saline & & $\begin{array}{c}\text { Ground- } \\
\text { water }\end{array}$ & $\begin{array}{c}\text { Surface } \\
\text { water }\end{array}$ & \\
\hline & 545 & 3,590 & 3,000 & 6,590 & 4,130 & 3,000 & 7,130 & 611 & 7,380 & 7,990 \\
\hline \multicolumn{11}{|c|}{ Sector } \\
\hline Power & 3.00 & 1,920 & 2,990 & 4,910 & 1,920 & 2,990 & 4,910 & 3.36 & 5,510 & 5,510 \\
\hline $\begin{array}{l}\text { Drinking } \\
\text { Water }\end{array}$ & 370 & 1,240 & 0 & 1,240 & 1,610 & 0 & 1,610 & 415 & 1,390 & 1,800 \\
\hline
\end{tabular}

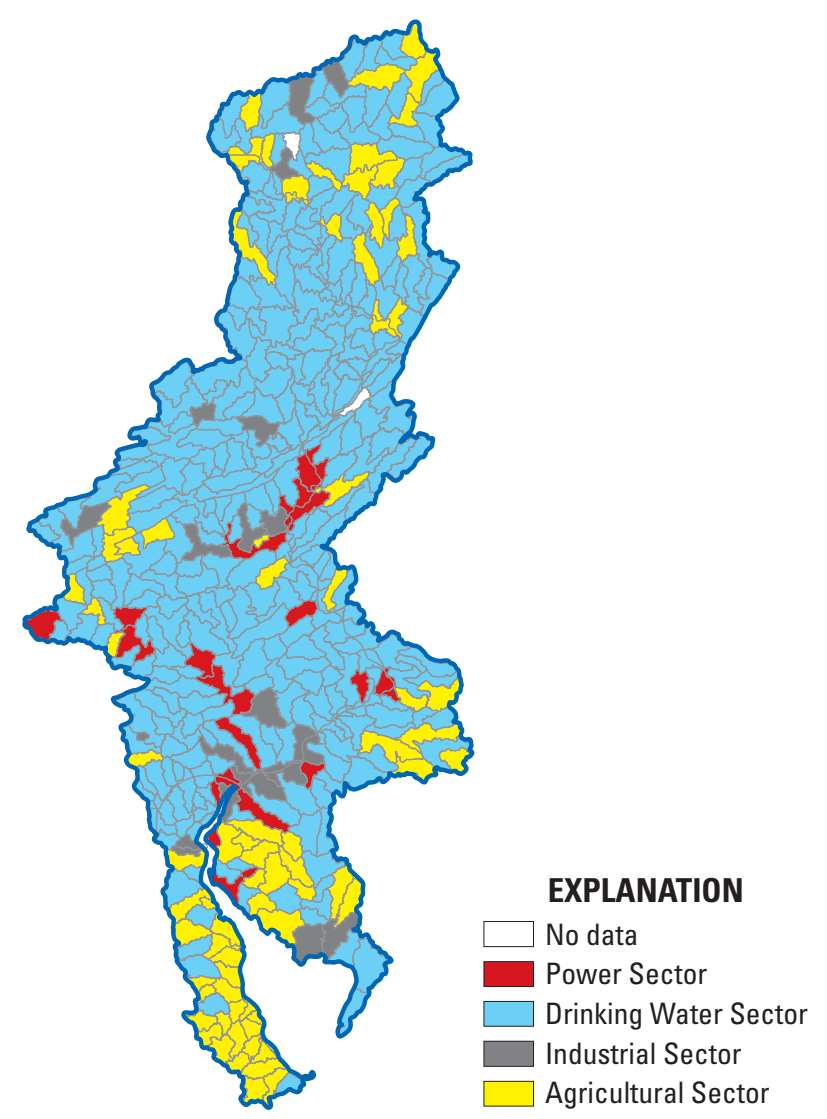

Figure 12. Sector with the largest water withdrawals by subwatershed in the Delaware River Basin, 2010. 


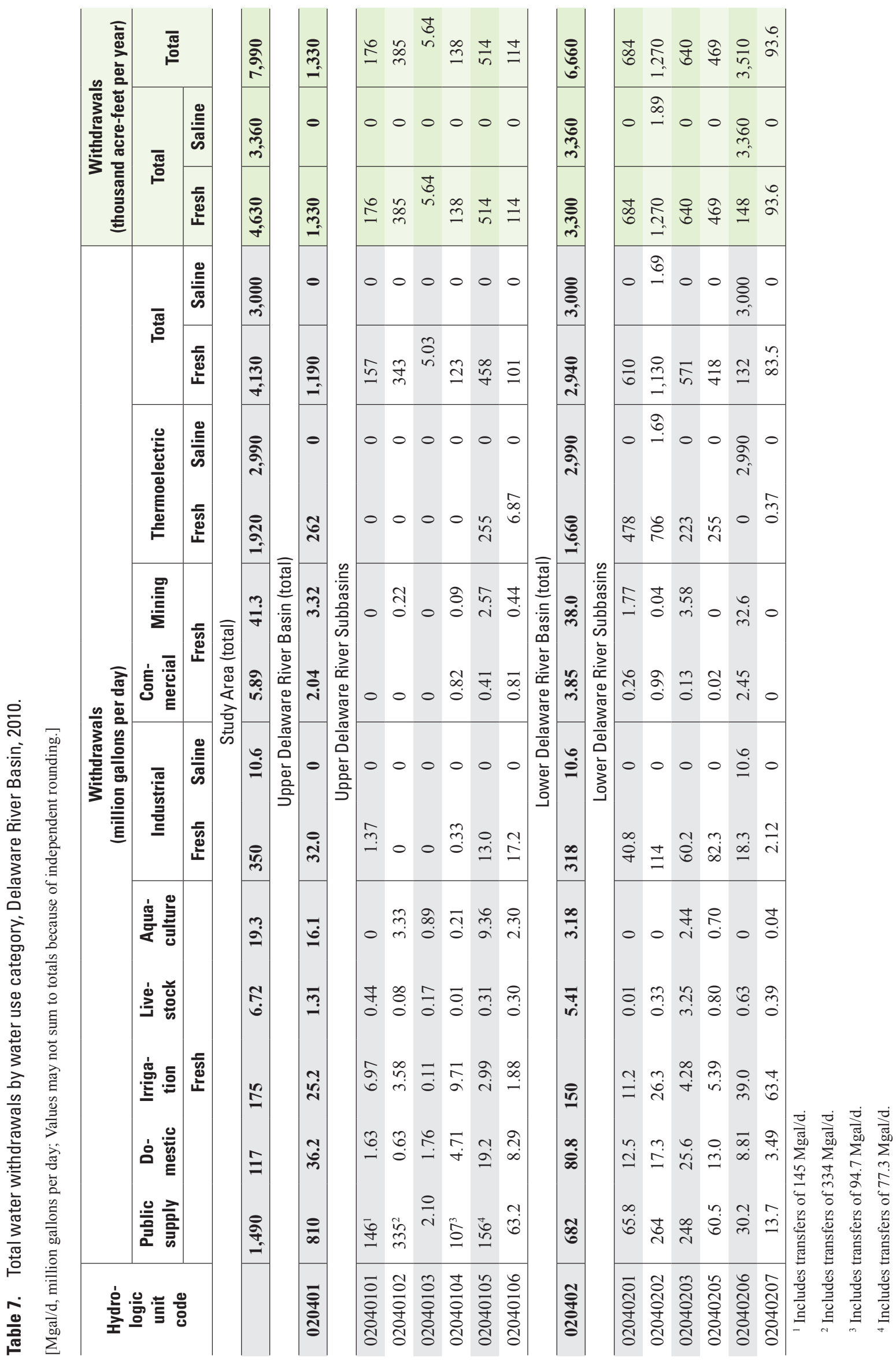




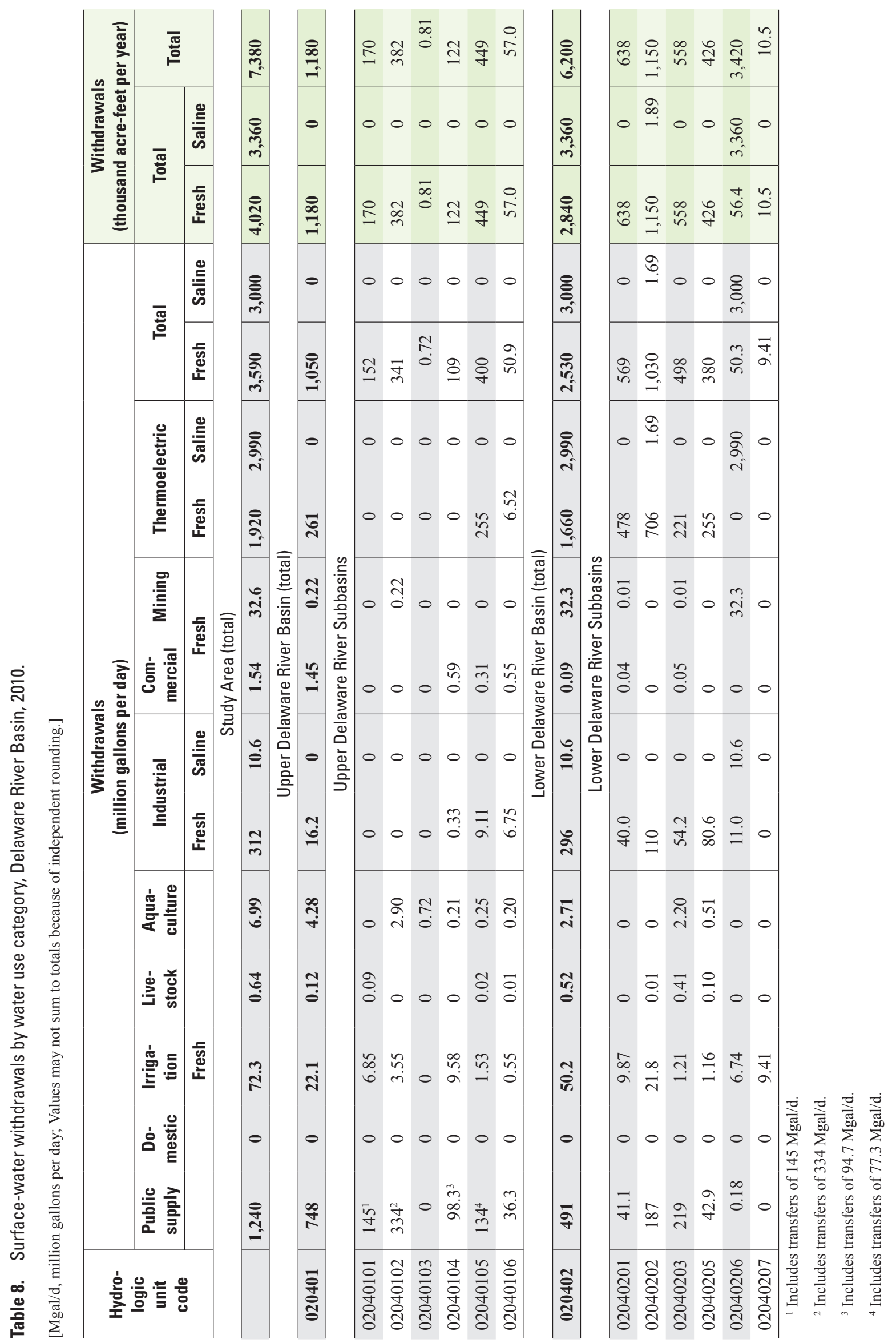




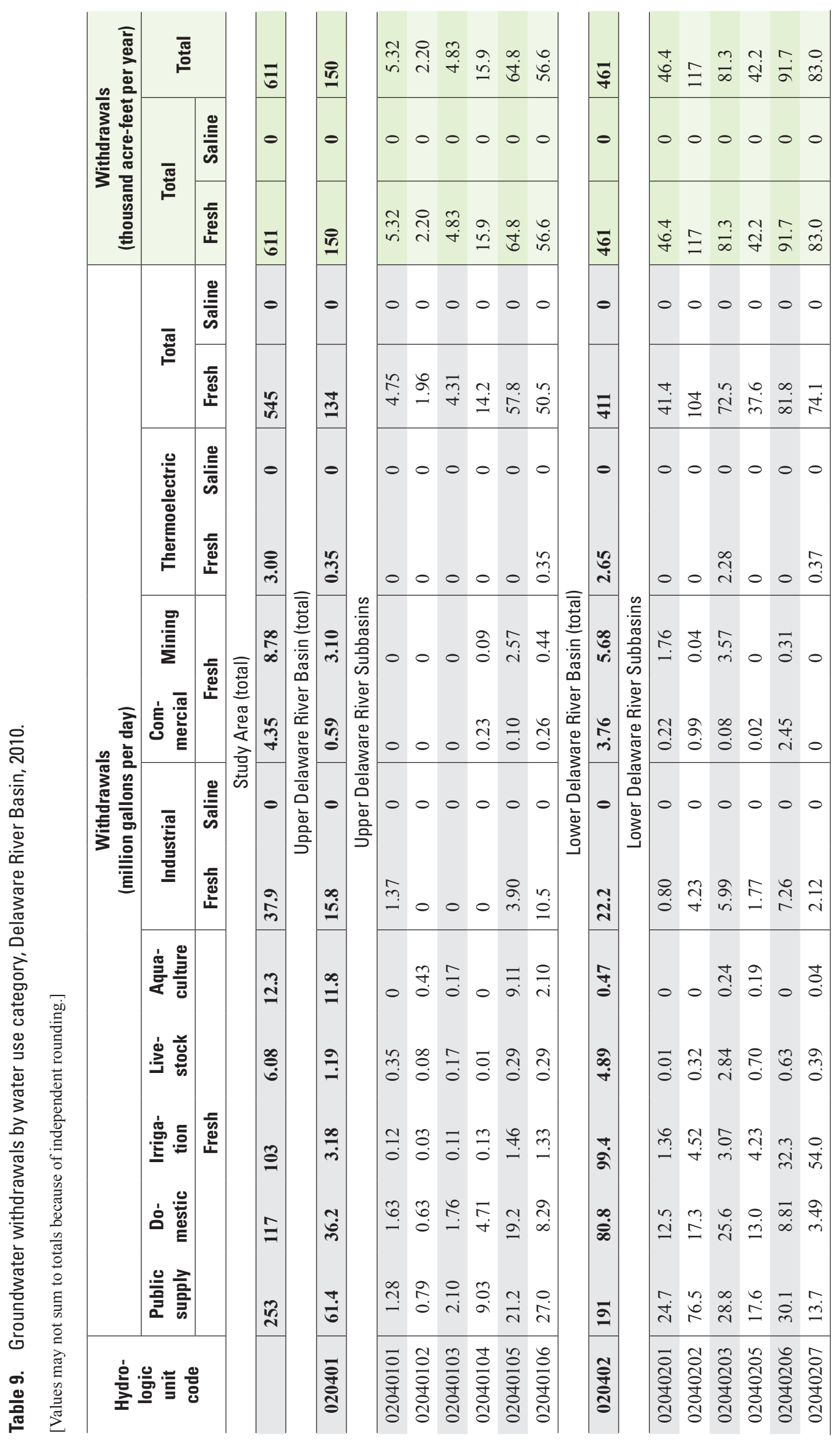


Table 10. Thermoelectric power water withdrawals, Delaware River Basin, 2010.

[Values may not sum to totals because of independent rounding.]

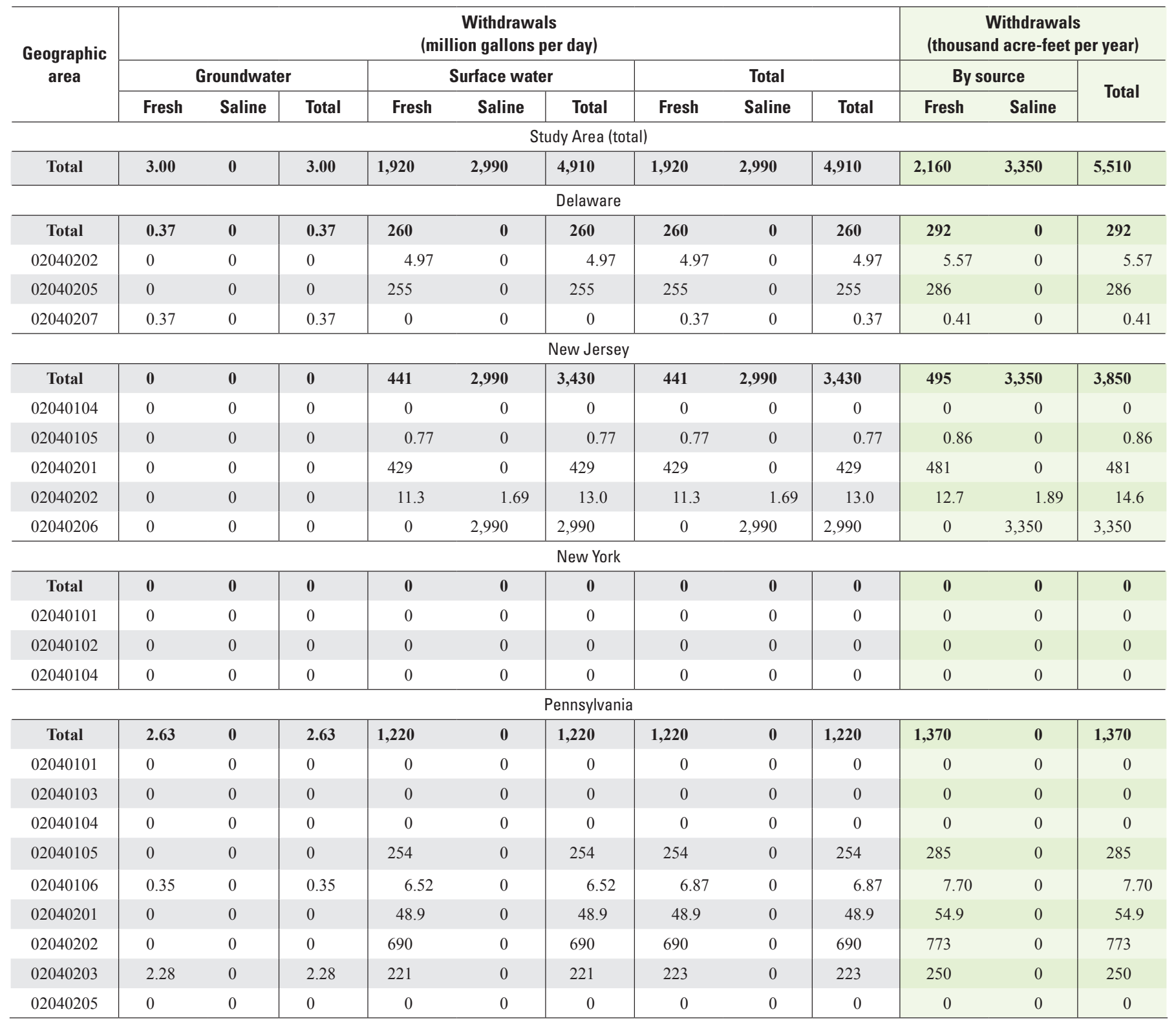

Table 11. Thermoelectric power generation water withdrawals by basin, Delaware River Basin, 2010.

[Values may not sum to totals because of independent rounding.]

\begin{tabular}{|c|c|c|c|c|c|c|c|c|}
\hline \multicolumn{9}{|c|}{ Withdrawals (million gallons per day) } \\
\hline \multicolumn{3}{|c|}{ Groundwater } & \multicolumn{3}{|c|}{ Surface water } & \multicolumn{3}{|c|}{ Total } \\
\hline Fresh & Saline & Total & Fresh & Saline & Total & Fresh & Saline & Total \\
\hline 3.00 & 0 & 3.00 & 1,920 & 2,990 & 4,910 & 1,920 & 2,990 & 4,910 \\
\hline \multicolumn{9}{|c|}{ Upper Delaware River Basin (total) } \\
\hline 2.65 & 0 & 2.65 & 1,660 & 2,990 & 4,650 & 1,660 & 2,990 & 4,650 \\
\hline
\end{tabular}




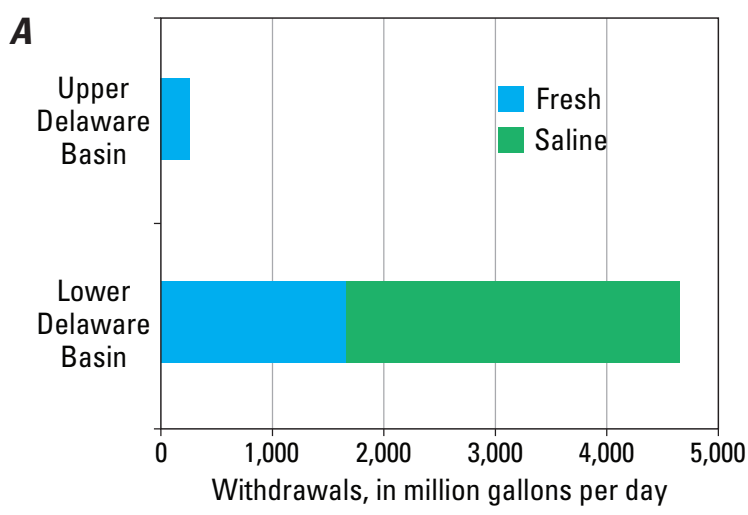

B

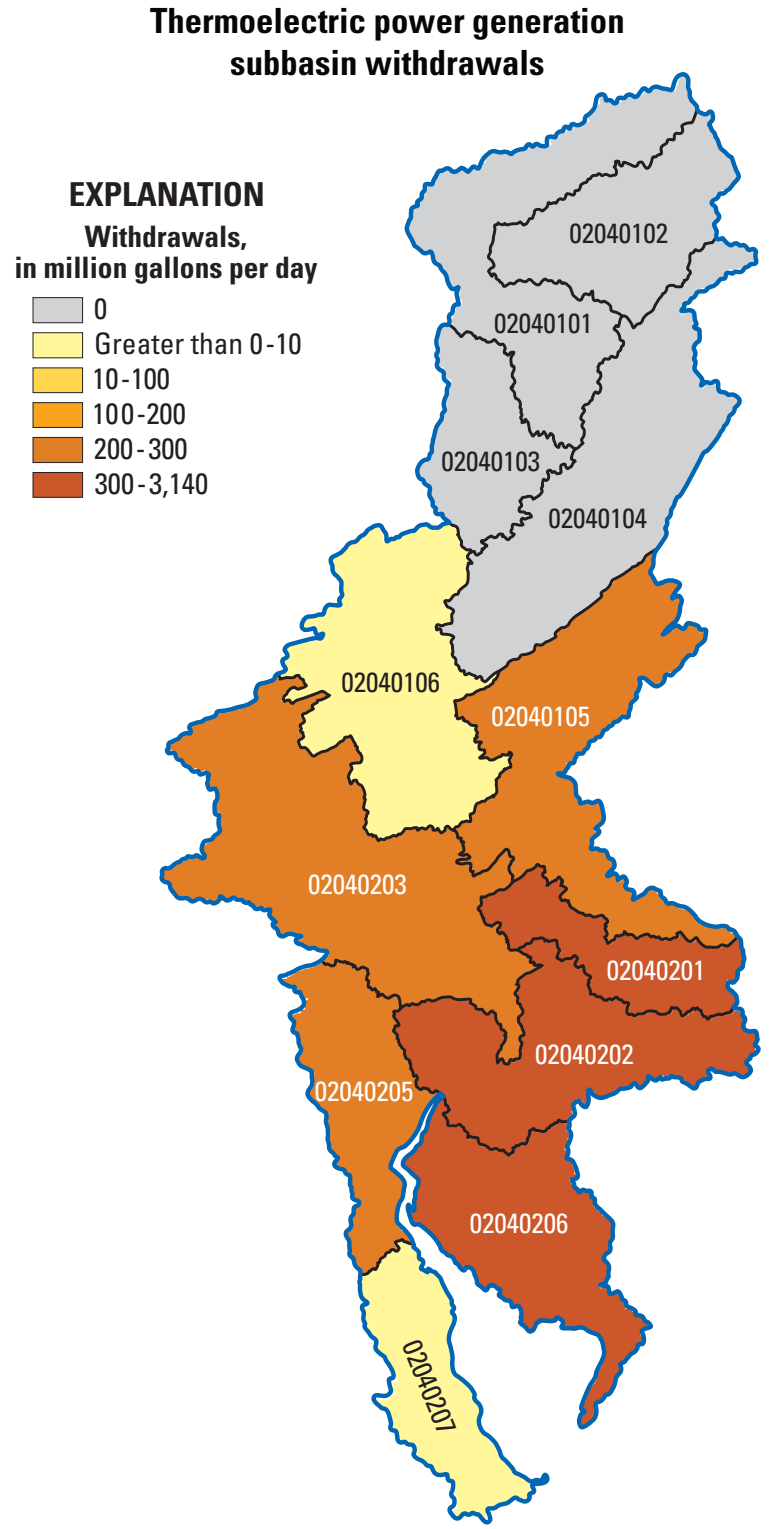

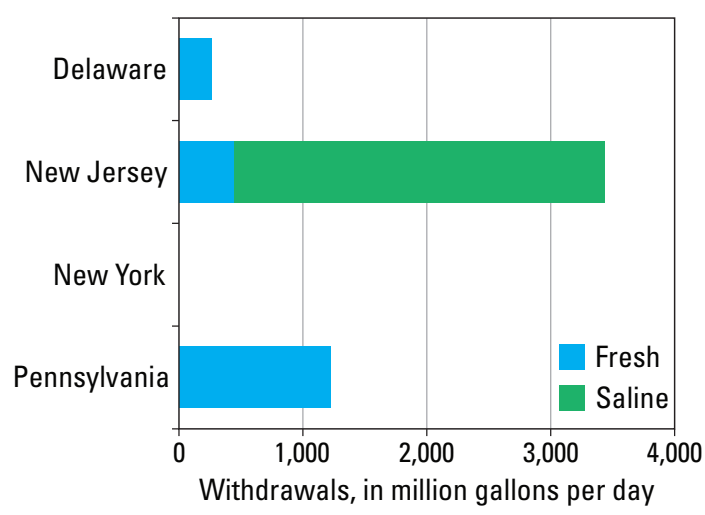

Thermoelectric power generation subwatershed withdrawals

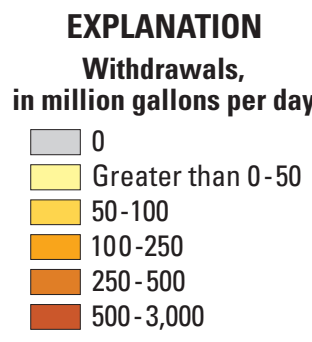

EXPLANATION

lion gallons per day

Greater than 0-50

$50-500$

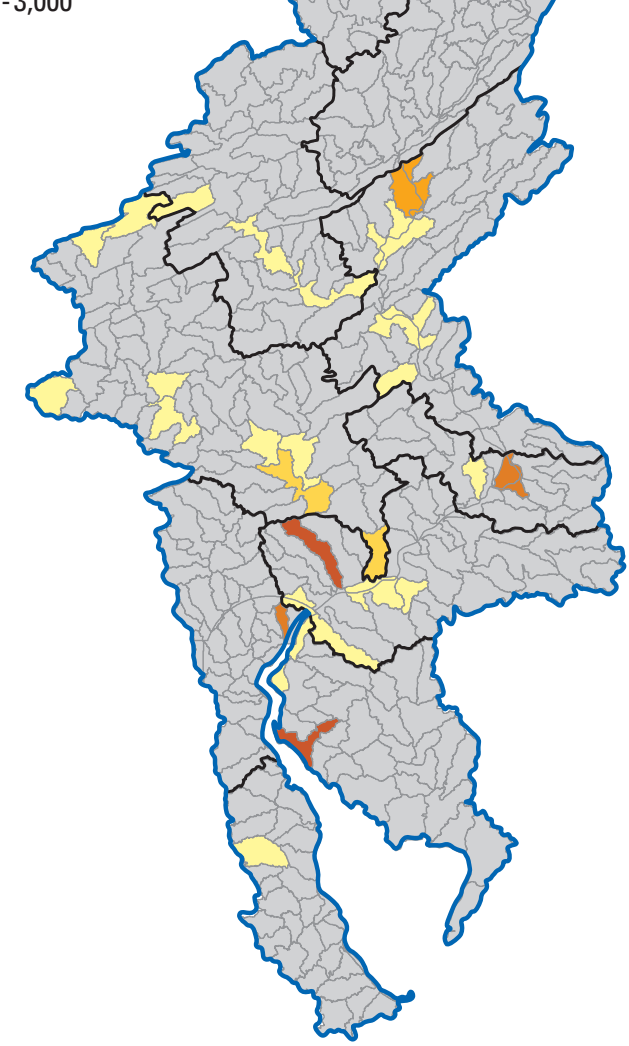

Figure 13. Distribution of thermoelectric power generation water withdrawals by $A$, type, basin, state, and $B$, subbasin and subwatershed in the Delaware River Basin, 2010. 


\section{Drinking Water Sector}

The drinking water sector consists of the public supply and self-supplied domestic water use categories. Total withdrawals of 1,610 Mgal/d for the Drinking Water sector represented 39 percent of the total freshwater withdrawals in the DRB in 2010 (table 12). Over three-quarters $(1,240 \mathrm{Mgal} / \mathrm{d})$ of the drinking water withdrawn was from surface-water sources, and less than a quarter $(370 \mathrm{Mgal} / \mathrm{d})$ was from groundwater sources (fig. 14a). Forty percent $(651 \mathrm{Mgal} / \mathrm{d})$ of the drinking water total was transferred out of the basin. Water withdrawn for public supply uses within the DRB ( $840 \mathrm{Mgal} / \mathrm{d})$ accounted for 52 percent of the water withdrawals for this sector. Self-supplied domestic (117 Mgal/d) accounted for the remaining withdrawals for this sector.

The Upper basin (020401) accounted for 53 percent (846 Mgal/d) of the total Drinking Water sector withdrawals, whereas the Lower basin (020402) accounted for 47 percent (763 Mgal/d) (fig. 14b). However, out-of-basin drinking water exports accounted for 77 percent $(651 \mathrm{Mgal} / \mathrm{d})$ of drinking water withdrawals in the Upper basin. Within basin drinking water withdrawals (excluding exports) for the Upper basin were about evenly split between surface water $(97.1 \mathrm{Mgal} / \mathrm{d})$ and groundwater $(97.6 \mathrm{Mgal} / \mathrm{d})$ sources. Upper basin selfsupplied domestic was $36.2 \mathrm{Mgal} / \mathrm{d}$, or about 19 percent of the Upper basin drinking water use. The Lower basin withdrawals were 64 percent (491 Mgal/d) surface water and 36 percent (272 Mgal/d) groundwater and were used primarily for public supply. Drinking Water sector use in the Lower basin includes $32.4 \mathrm{Mgal} / \mathrm{d}$ of water that is transferred in (imported) from the Susquehanna River Basin in Pennsylvania. Lower basin selfsupplied domestic withdrawals were $80.8 \mathrm{Mgal} / \mathrm{d}$, or about 10 percent of the Lower basin drinking water use.

The geographic distribution of total Drinking Water sector water withdrawals by subbasin is shown in figure 14c. Sector withdrawals are dominated by public supply water withdrawals in the Upper basin for New York City and in the Lower basin for the greater Philadelphia area.

\section{Public Supply}

Total water withdrawals in the DRB for the public supply category were 1,490 Mgal/d (table 13), or 1,670 thousand acre-ft/yr in 2010. Public supply represents about 36 percent of total freshwater withdrawals and about 68 percent of all withdrawals not including thermoelectric power. Approximately 83 percent $(1,240 \mathrm{Mgal} / \mathrm{d})$ of water withdrawn for public supply in the DRB was from surface sources, such as reservoirs, lakes, and streams; the other 17 percent (253 Mgal/d) was from groundwater (fig. 15).

An estimated 14.7 million people relied on drinking water withdrawn in the DRB for their household use; over 8 million people outside of the basin (in New York City and New Jersey) and 6.7 million people within the DRB. The publicly supplied population of the DRB represents about 81 percent of the total 2010 DRB population of approximately 8.2 million people. The subbasins with the largest water withdrawals for public supply were those in which withdrawals for New York City, New York; Philadelphia, Pennsylvania; and Trenton, New Jersey occurred. Approximately $651 \mathrm{Mgal} / \mathrm{d}$ were transferred out of the DRB and $32.4 \mathrm{Mgal} / \mathrm{d}$ were transferred into the DRB.

Over three-quarters $(1,160 \mathrm{Mgal} / \mathrm{d})$ of the water withdrawn for public supply was withdrawn in New York and Pennsylvania. Almost 40 percent of the total was withdrawn in New York and was transferred out of the DRB to New York City. Water withdrawn by public suppliers for use within the DRB was primarily from surface-water sources in Pennsylvania (86 percent surface water; 14 percent groundwater), groundwater sources in New Jersey (31 percent surface water; 69 percent groundwater) and in New York (21 percent surface water; 79 percent groundwater); and almost equally split between sources in Delaware (55 percent surface water; 45 percent groundwater).

Three subbasins (02040103, 02040206, and 02040207) had public supply withdrawals almost exclusively (greater than 99 percent) from groundwater sources, most likely

Table 12. Drinking Water sector water withdrawals, Delaware River Basin, 2010.

[Values may not sum to totals because of independent rounding.]

\begin{tabular}{|c|c|c|c|c|c|c|c|c|c|c|c|}
\hline \multicolumn{9}{|c|}{$\begin{array}{c}\text { Withdrawals } \\
\text { (million gallons per day) }\end{array}$} & \multicolumn{3}{|c|}{$\begin{array}{c}\text { Water use } \\
\text { (million gallons per day) }\end{array}$} \\
\hline \multicolumn{3}{|c|}{ Public supply } & \multicolumn{3}{|c|}{ Domestic } & \multicolumn{2}{|c|}{ Total } & Total & \multicolumn{2}{|c|}{ Transfers } & Total use \\
\hline \multicolumn{12}{|c|}{ Study Area (total) } \\
\hline 253 & 1,240 & 1,490 & 117 & 0 & 117 & 370 & 1,240 & 1,610 & 32.4 & 651 & 990 \\
\hline 61.4 & 748 & 810 & 36.2 & 0 & 36.2 & 97.6 & 748 & 846 & 0 & 651 & 195 \\
\hline \multicolumn{12}{|c|}{ Lower Delaware River Basin (total) } \\
\hline 191 & 491 & 682 & 80.8 & 0 & 80.8 & 272 & 491 & 763 & 32.4 & 0 & 795 \\
\hline
\end{tabular}


Upper Delaware Basin

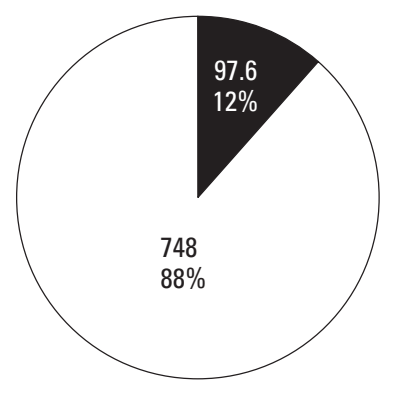

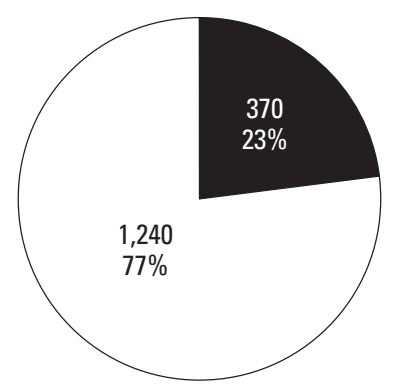

Groundwater

Surface water
Lower Delaware Basin

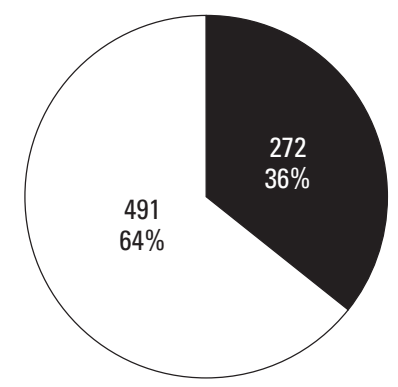

B

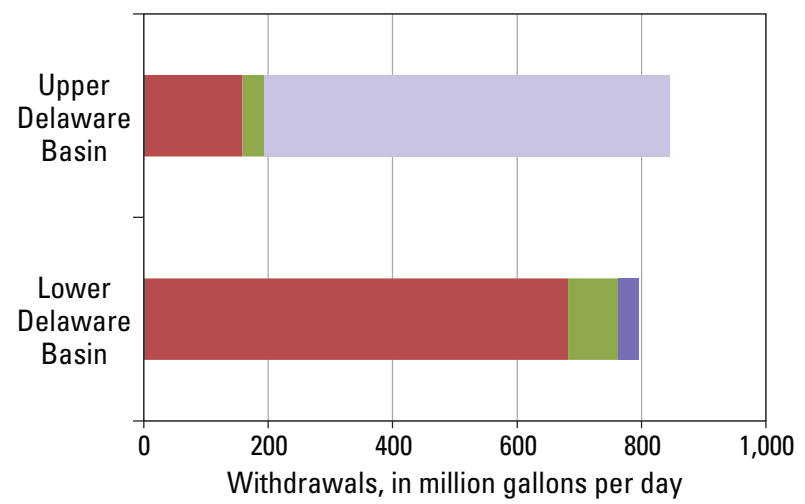

Public Supply

Self-supplied domestic

Transfers out (exports)

Transfers in (imports)

Figure 14. Distribution of water withdrawals for the Drinking Water sector in the Delaware River Basin, 2010, by $A$, source and basin, $B$, basin and water use category, and $C$, subbasin and source. (\%, percent)

because these basins have low to moderate populations and access to productive aquifers (glaciofluvial for the first subbasin, Coastal Plain for the latter two) (fig. 16). Two subbasins (02040101 and 02040102) had public supply withdrawals almost exclusively (greater than 99 percent) from surfacewater sources due to the withdrawal and subsequent transfer of water to New York City; however, groundwater sources account for most of the publicly supplied water use for residents within these two subbasins of the DRB.

The six subwatersheds with the largest surface-water withdrawals were the three subwatersheds that include reservoirs that are part of the New York City supply system (020401020405, Pepacton Reservoir, 334 Mgal/d;
020401010207, Cannonsville Reservoir, $145 \mathrm{Mgal} / \mathrm{d}$; and 020401040303, Neversink Reservoir, 94.7 Mgal/d) and the three subwatersheds where water is withdrawn to supply the City of Philadelphia (020402031008, $121 \mathrm{Mgal} / \mathrm{d})$, the Cities of Camden (020401050803, 77.3 Mgal/d), and Trenton, New Jersey (020402020305, $178 \mathrm{Mgal} / \mathrm{d})$ along with other uses along the D \& R Canal. The four subwatersheds with the largest groundwater withdrawals were 020401060703 (12.5 Mgal/d, in the vicinity of Allentown, Pennsylvania) and three subwatersheds in the vicinity of Camden, New Jersey (020402020401, 15.2 Mgal/d; 020402020404, $11.8 \mathrm{Mgal} / \mathrm{d}$; and $020402020403,10.2 \mathrm{Mgal} / \mathrm{d}$ ). 


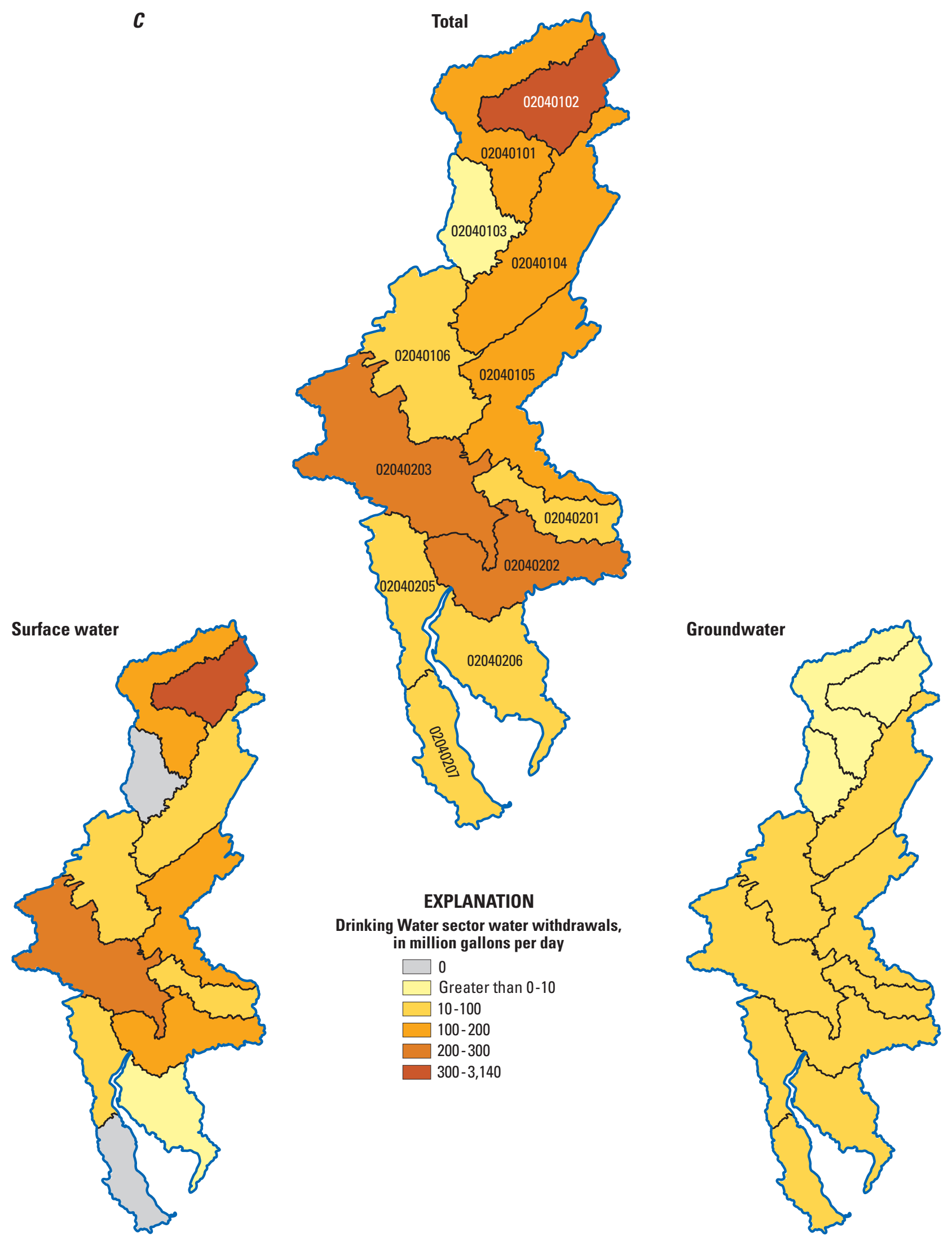

Figure 14. Distribution of water withdrawals for the Drinking Water sector in the Delaware River Basin, 2010, by $A$, source and basin, $B$, basin and water use category, and $C$, subbasin and source. (\%, percent)—Continued 
Table 13. Public supply water withdrawals and transfers, Delaware River Basin, 2010.

[Values may not sum to totals because of independent rounding.]

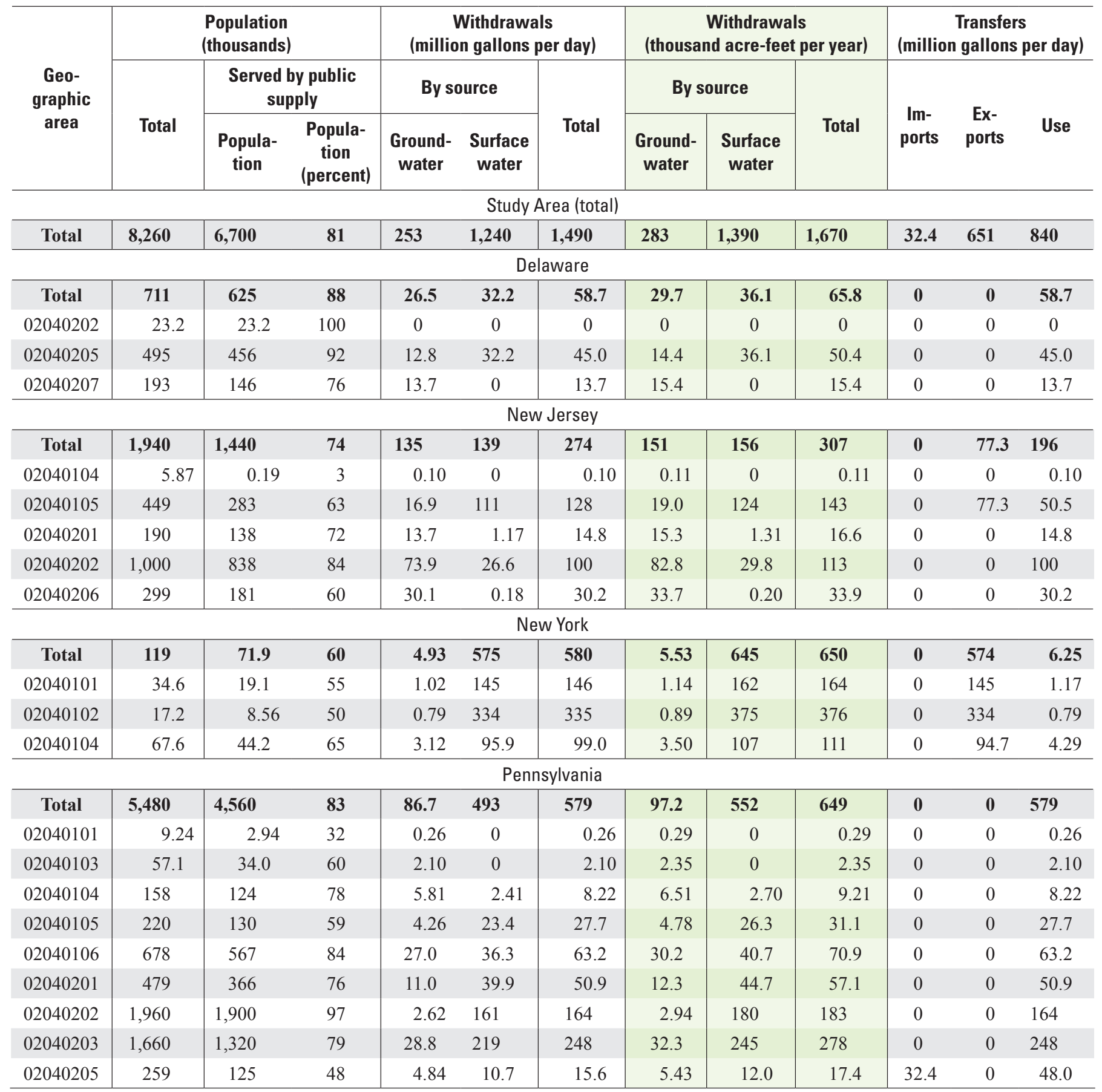




\section{Public Supply Withdrawals}

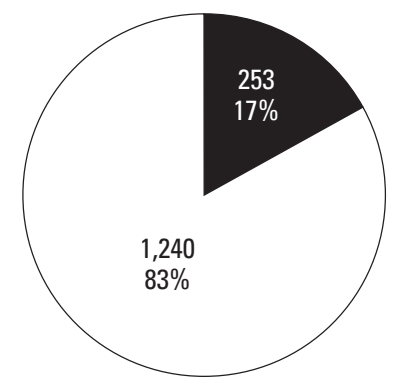

Groundwater

$\square$ Surface water
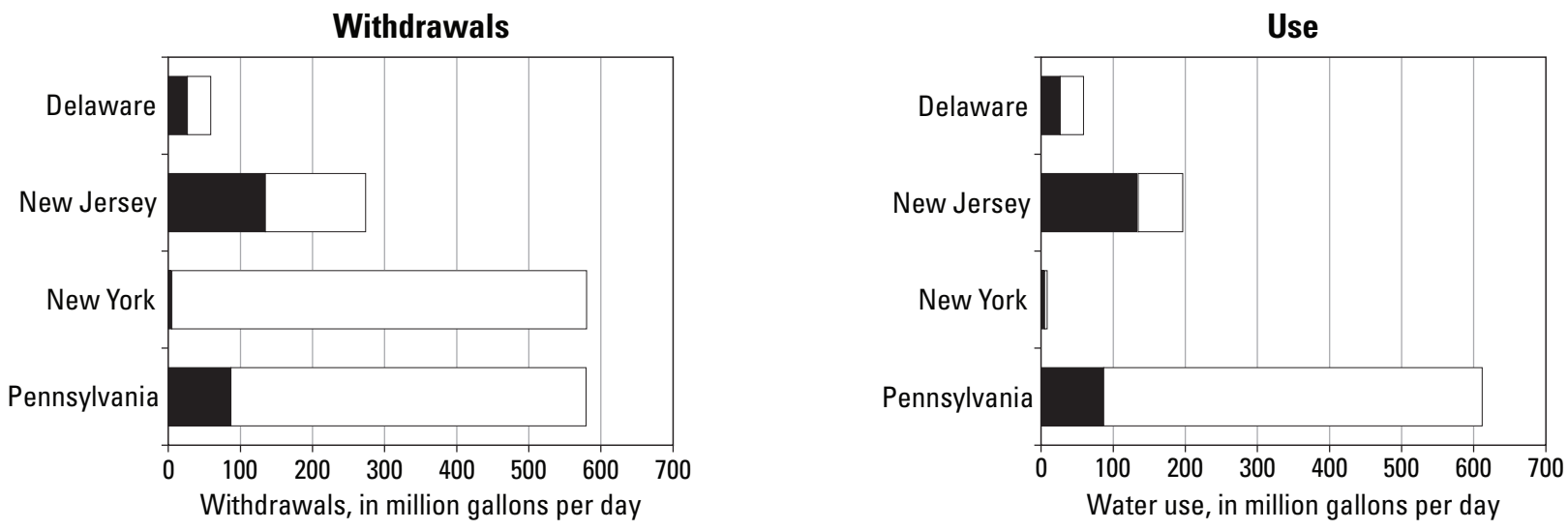

Figure 15. Distribution of public supply water withdrawals and use by source and state in the Delaware River Basin, 2010. (\%, percent) 

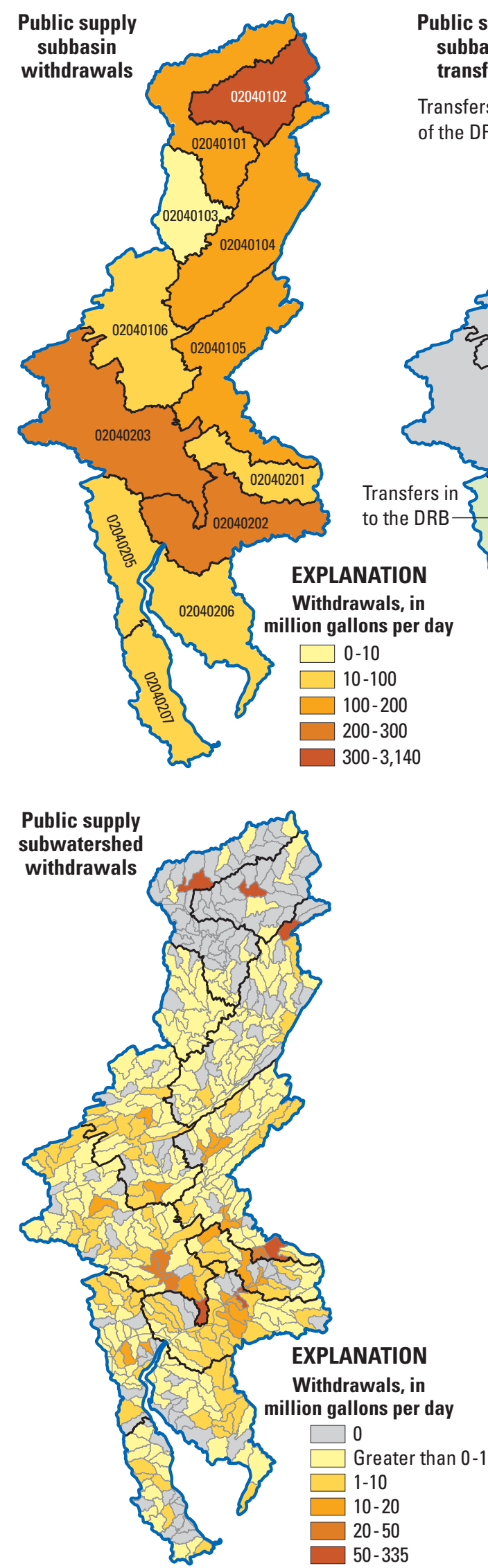

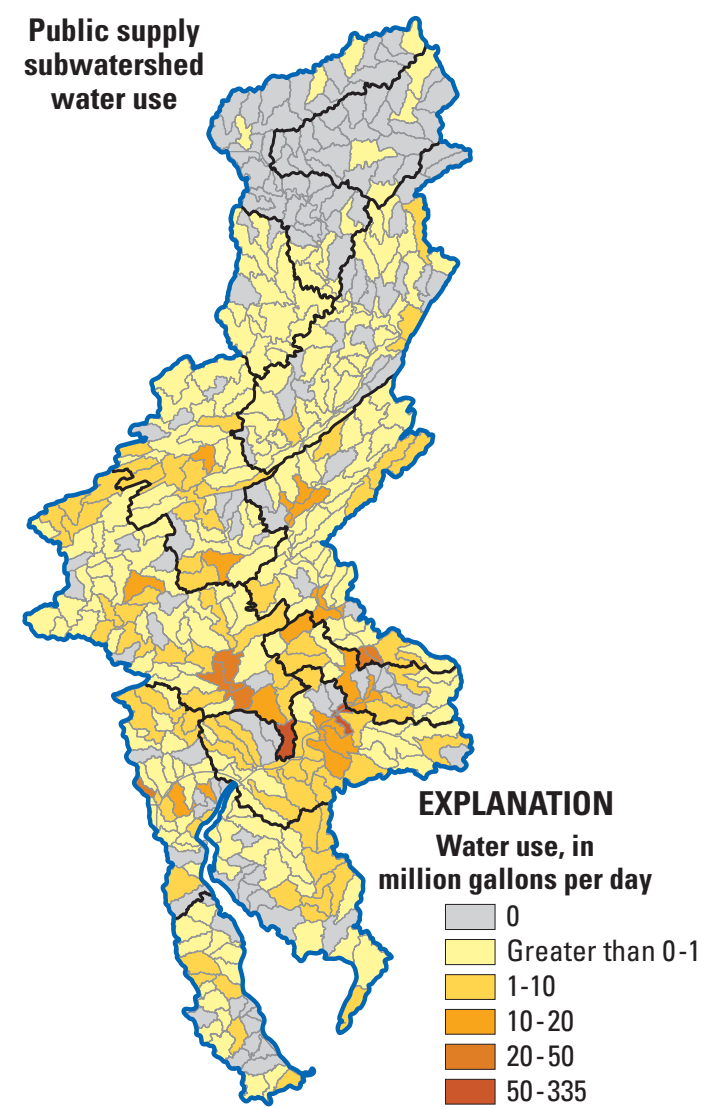

Figure 16. Public supply water withdrawals, transfers, and use by source, subbasin, and subwatershed in the Delaware River Basin, 2010. 

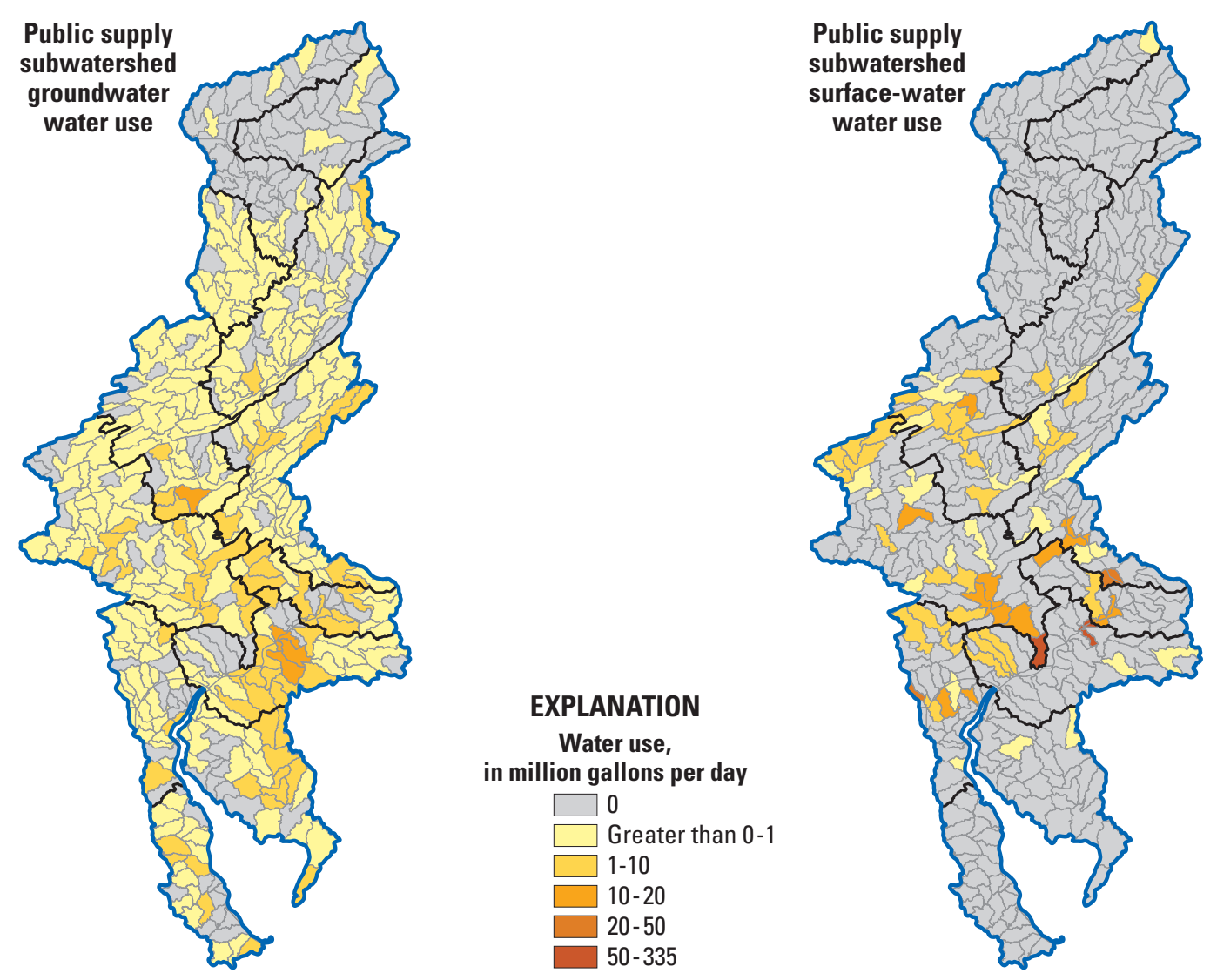

Figure 16. Public supply water withdrawals, transfers, and use by source, subbasin, and subwatershed in the Delaware River Basin, 2010.-Continued

\section{Self-Supplied Domestic}

Total water withdrawals in the DRB for the self-supplied domestic category were $117 \mathrm{Mgal} / \mathrm{d}$ (table 14), or 131 thousand acre-ft/yr in 2010. Self-supplied domestic represents about 3 percent of total freshwater withdrawals and about 5 percent of all withdrawals not including thermoelectric power. Totals for this category were almost exclusively (greater than 99 percent) calculated based on areal estimates.

An estimated 1.56 million people within the DRB supplied their own water for domestic use in 2010. This number represents about 19 percent of the total $2010 \mathrm{DRB}$ population of approximately 8.2 million people. Over half (62.2 Mgal/d) of the self-supplied domestic withdrawals were from three subbasins (02040203, 02040105, and 02040202) (fig. 17), which contained 64 percent of the DRB total population. Selfsupplied domestic withdrawals were greatest outside of metropolitan areas such as Philadelphia, Pennsylvania; Wilmington, Delaware; and Trenton, New Jersey.

Over 90 percent $(107 \mathrm{Mgal} / \mathrm{d})$ of the water withdrawn for self-supplied domestic use was withdrawn in Pennsylvania and New Jersey, where the majority (90 percent) of the DRB population resides (fig. 18). Almost one-quarter (25.6 Mgal/d) of that water was withdrawn in Pennsylvania from subbasin 02040203, which includes areas outside of Philadelphia. 
Table 14. Self-supplied domestic water withdrawals, Delaware River Basin, 2010.

[Values may not sum to totals because of independent rounding.]

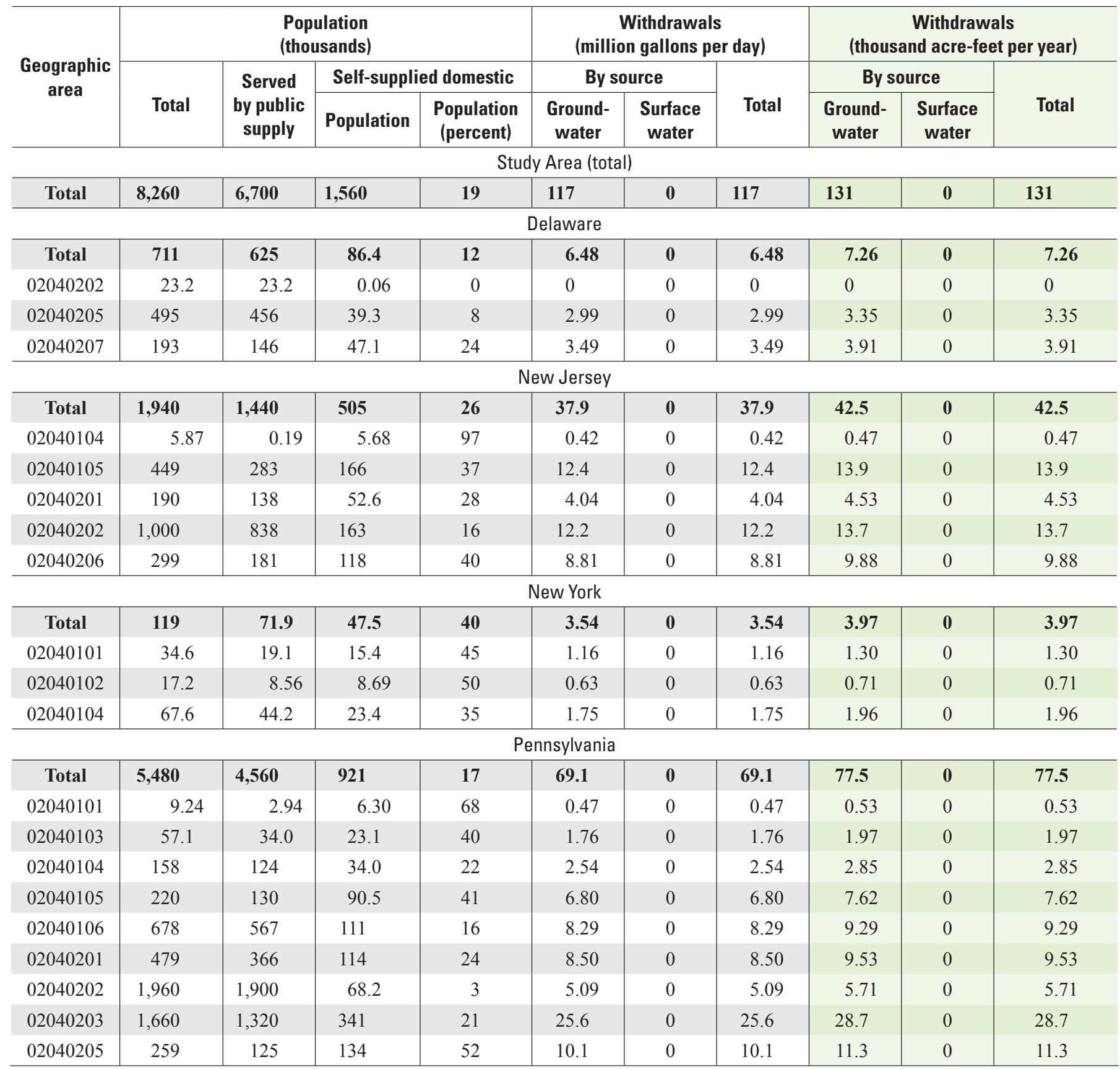




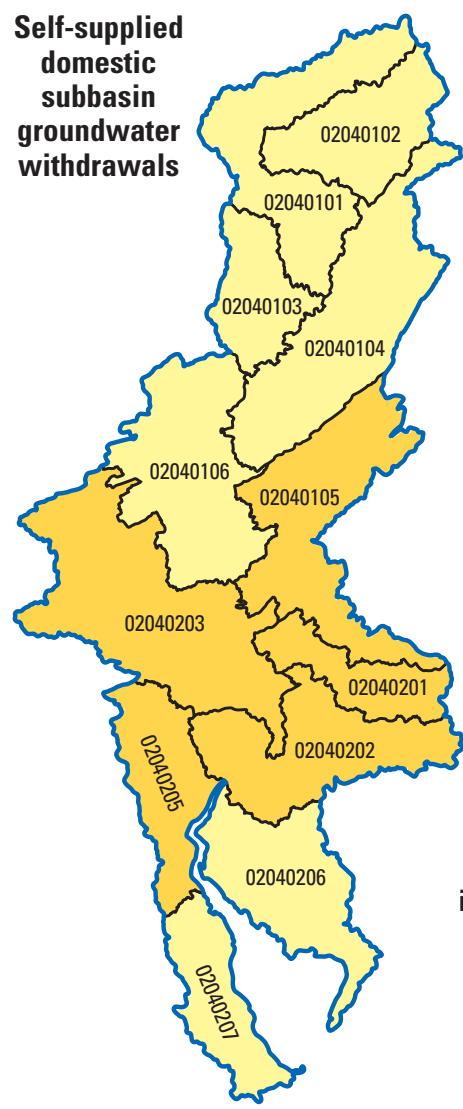

EXPLANATION

Withdrawals, in million gallons per day

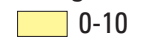

$\square$ 10-100

$100-200$

200-300

300-3,140

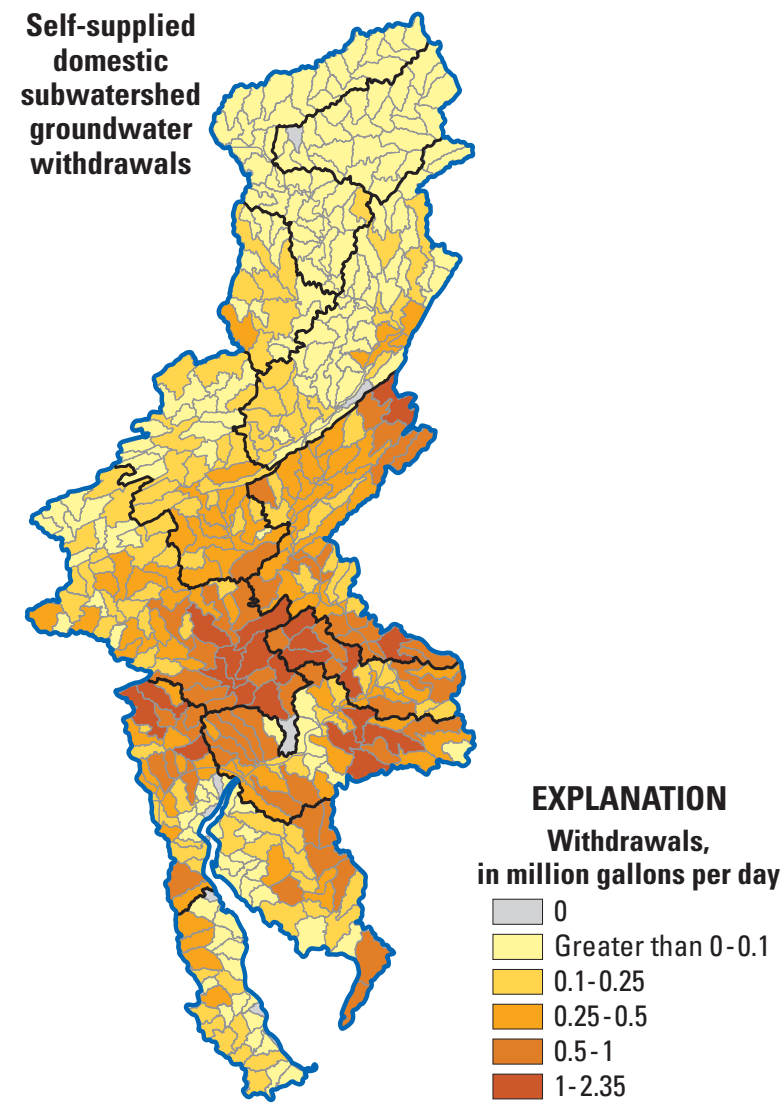

Figure 17. Self-supplied domestic groundwater withdrawals by subbasin and subwatershed in the Delaware River Basin, 2010.

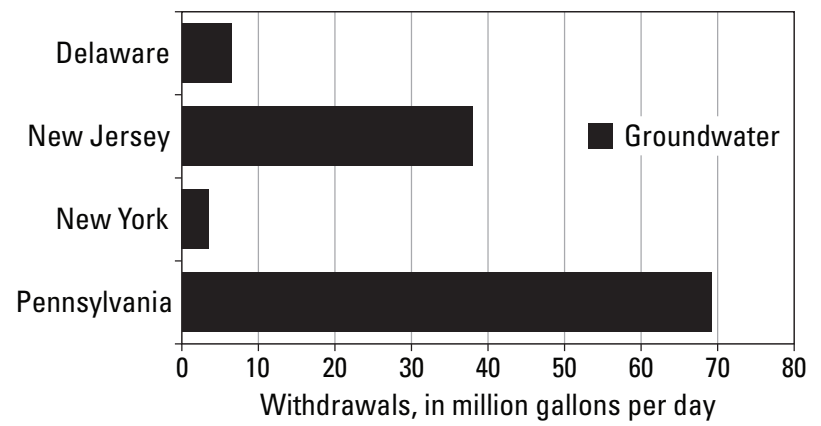

Figure 18. Distribution of domestic water withdrawals by state in the Delaware River Basin, 2010. 


\section{Industrial Sector}

The Industrial sector consists of the industrial, commercial, and mining categories. Total withdrawals of $408 \mathrm{Mgal} / \mathrm{d}$ for the Industrial sector represented 10 percent of the total freshwater withdrawals in the DRB in 2010 (table 15). Eightyseven percent $(357 \mathrm{Mgal} / \mathrm{d})$ of the water withdrawn was from surface-water sources, and 13 percent (51.1 Mgal/d) was from groundwater sources (fig. 19a). Industrial withdrawals (361 Mgal/d) accounted for 88 percent of the water withdrawals for this sector, mining water withdrawals (41.3 Mgal/d) accounted for 10 percent, and commercial water withdrawals (5.89 Mgal/d) accounted for the remaining amount.

The Lower basin accounted for 91 percent (371 Mgal/d) of the total Industrial sector withdrawals, whereas the Upper basin accounted for 9 percent (37.3 Mgal/d) (fig. 19b). The Lower basin Industrial sector water withdrawals were 91 percent from surface-water sources (339 Mgal/d) and 9 percent (31.6 Mgal/d) from groundwater sources. The Upper basin Industrial sector withdrawals were almost equally distributed between sources, with 52 percent from groundwater sources (19.5 Mgal/d) and 48 percent from surface-water sources (17.9 Mgal/d).

The geographic distribution of total Industrial sector water withdrawals by subbasin is shown in figure 19c. Sector withdrawals are dominated by industrial withdrawals in Pennsylvania, Delaware, and New Jersey.

\section{Industrial}

Total water withdrawals in the DRB for the industrial category were $361 \mathrm{Mgal} / \mathrm{d}$ (table 16), or 404 thousand acre-ft/ $\mathrm{yr}$ in 2010. Industrial represents 8 percent of total freshwater withdrawals and 16 percent of all withdrawals not including thermoelectric power. Approximately 89 percent (323 Mgal/d) of water withdrawn for industrial use in the DRB was from surface-water sources; the other 11 percent (37.9 Mgal/d) was from groundwater sources (fig. 20).

The four subbasins with the largest water withdrawals for industrial (02040202, 02040205, 02040203, and 02040201) accounted for 83 percent $(298 \mathrm{Mgal} / \mathrm{d})$ of the industrial water withdrawn in the DRB (fig. 21). These subbasins include the urban areas surrounding Camden and Trenton, New Jersey; Philadelphia, Pennsylvania; and Wilmington, Delaware. The four subwatersheds with the largest surface-water withdrawals, also located near these urban areas, were 020402020607 (73.9 Mgal/d), 020402050704 (71.4 Mgal/d), 020402010404 (38.4 Mgal/d), and 020402031008 (27.4 Mgal/d). One subbasin, the Lower Delaware (02040202), had industrial surfacewater withdrawals that accounted for 34 percent $(110 \mathrm{Mgal} / \mathrm{d})$ of the total for the DRB. Another subbasin, the Lehigh River (02040106), accounted for 28 percent (10.5 Mgal/d) of industrial groundwater withdrawals, most of which were from the carbonate aquifer in the Lehigh Valley. The subwatershed with the largest groundwater withdrawals $(5.62 \mathrm{Mgal} / \mathrm{d})$ was 020401060810 , in the vicinity of Allentown and Bethlehem, Pennsylvania. The only subwatershed where saline surfacewater withdrawals were reported was 020402060103 (10.6 $\mathrm{Mgal} / \mathrm{d})$, near Wilmington, Delaware.

Water withdrawals for industrial use were greatest in Pennsylvania (212 Mgal/d), Delaware (81.6 Mgal/d), and New Jersey $(65.4 \mathrm{Mgal} / \mathrm{d})$; less than 1 percent of industrial withdrawals occurred in New York (fig. 20). Twenty-four percent $(87.5 \mathrm{Mgal} / \mathrm{d})$ of the industrial water withdrawn in the DRB was from the part of subbasin 02040203 that is in Pennsylvania and 22 percent $(79.4 \mathrm{Mgal} / \mathrm{d})$ was withdrawn from subbasin 02040205 in Delaware. 
Table 15. Industrial sector water withdrawals, Delaware River Basin, 2010.

[Values may not sum to totals because of independent rounding.]

Withdrawals

(million gallons per day)

\begin{tabular}{|c|c|c|c|c|c|c|c|c|c|c|c|}
\hline \multicolumn{3}{|c|}{ Industrial } & \multicolumn{3}{|c|}{ Commercial } & \multicolumn{3}{|c|}{ Mining } & \multicolumn{3}{|c|}{ Total } \\
\hline $\begin{array}{c}\text { Ground- } \\
\text { water }\end{array}$ & $\begin{array}{c}\text { Surface } \\
\text { water }\end{array}$ & Total & $\begin{array}{c}\text { Ground- } \\
\text { water }\end{array}$ & $\begin{array}{c}\text { Surface } \\
\text { water }\end{array}$ & Total & $\begin{array}{c}\text { Ground- } \\
\text { water }\end{array}$ & $\begin{array}{c}\text { Surface } \\
\text { water }\end{array}$ & Total & $\begin{array}{c}\text { Ground- } \\
\text { water }\end{array}$ & $\begin{array}{c}\text { Surface } \\
\text { water }\end{array}$ & Total \\
\hline \multicolumn{12}{|c|}{ Study Area (total) } \\
\hline 37.9 & 323 & 361 & 4.35 & 1.54 & 5.89 & 8.78 & 32.6 & 41.3 & 51.1 & 357 & 408 \\
\hline \multicolumn{12}{|c|}{ Upper Delaware River Basin (total) } \\
\hline 15.8 & 16.2 & 32.0 & 0.59 & 1.45 & 2.04 & 3.10 & 0.22 & 3.32 & 19.5 & 17.9 & 37.3 \\
\hline \multicolumn{12}{|c|}{ Lower Delaware River Basin (total) } \\
\hline 22.2 & 307 & 329 & 3.76 & 0.09 & 3.85 & 5.68 & 32.3 & 38.0 & 31.6 & 339 & 371 \\
\hline
\end{tabular}

\section{A Industrial Sector Withdrawals}

Upper Delaware Basin

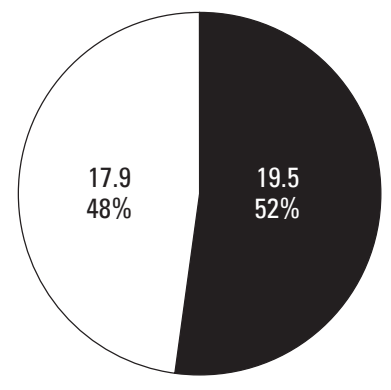

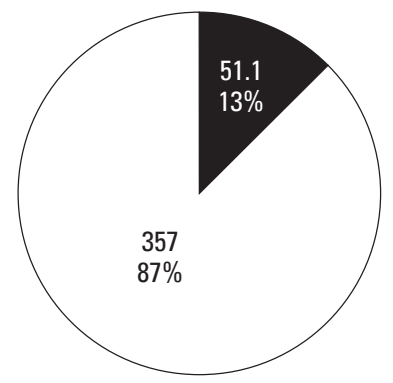

Surface water

\section{Lower Delaware Basin}

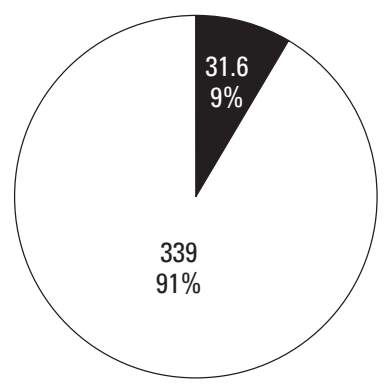

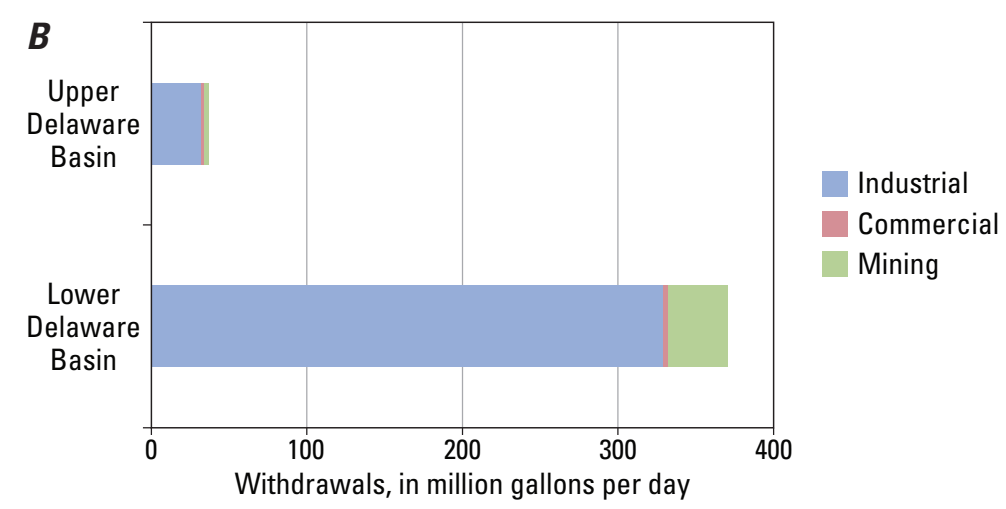

Figure 19. Distribution of water withdrawals for the Industrial sector in the Delaware River Basin, 2010 , by $A$, source and basin, $B$, basin and water use category, and $C$, subbasin and source.

(\%, percent) 

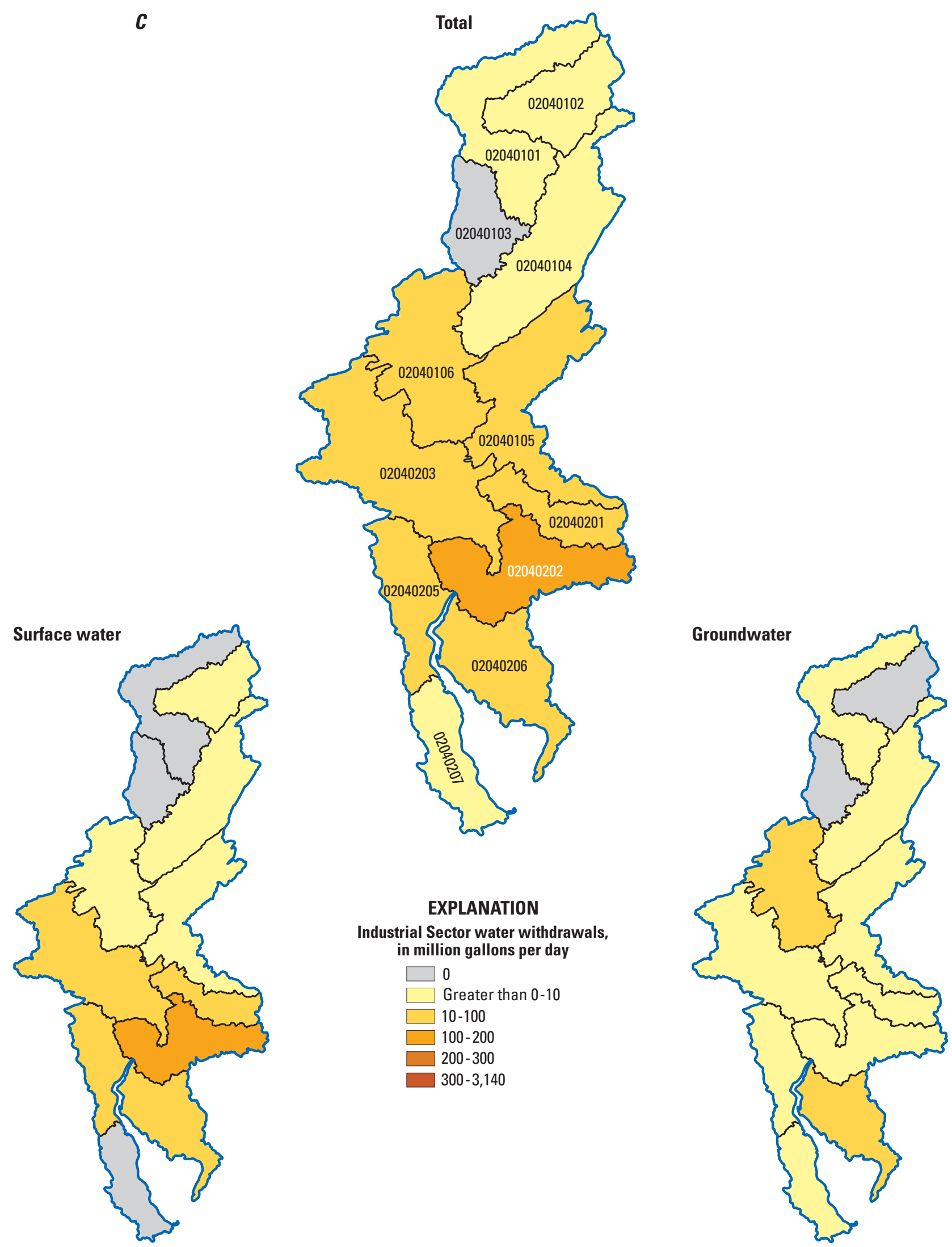

Figure 19. Distribution of water withdrawals for the Industrial sector in the Delaware River Basin, 2010, by $A$, source and basin, $B$, basin and water use category, and $C$, subbasin and source. (\%, percent)-Continued 
Table 16. Industrial water withdrawals, Delaware River Basin, 2010.

[Mgal/d, million gallons per day; Values may not sum to totals because of independent rounding.]

\begin{tabular}{|c|c|c|c|c|c|c|}
\hline \multirow{2}{*}{$\begin{array}{l}\text { Geographic } \\
\text { area }\end{array}$} & \multicolumn{3}{|c|}{$\begin{array}{c}\text { Withdrawals } \\
\text { (million gallons per day) }\end{array}$} & \multicolumn{3}{|c|}{$\begin{array}{c}\text { Withdrawals } \\
\text { (thousand acre-feet per year) }\end{array}$} \\
\hline & \multicolumn{2}{|c|}{ By source } & Total & \multicolumn{2}{|c|}{ By source } & Total \\
\hline \multicolumn{7}{|c|}{ Study Area (total) } \\
\hline Total & 37.9 & 323 & 361 & 42.6 & 362 & 404 \\
\hline \multicolumn{7}{|c|}{ Delaware } \\
\hline 02040202 & 0 & 0 & 0 & 0 & 0 & 0 \\
\hline 02040205 & 1.57 & 77.9 & 79.4 & 1.76 & 87.3 & 89.1 \\
\hline 02040207 & 2.12 & 0 & 2.12 & 2.38 & 0 & 2.38 \\
\hline \multicolumn{7}{|c|}{ New Jersey } \\
\hline 02040201 & 0.74 & 0.75 & 1.49 & 0.83 & 0.84 & 1.67 \\
\hline 02040202 & 4.12 & 22.7 & 26.8 & 4.62 & 25.5 & 30.1 \\
\hline 02040206 & 7.26 & $21.6^{1}$ & 28.9 & 8.14 & 24.2 & 32.4 \\
\hline \multicolumn{7}{|c|}{ New York } \\
\hline Total & 1.37 & $\mathbf{0}$ & 1.37 & 1.54 & $\mathbf{0}$ & 1.54 \\
\hline 02040101 & 1.37 & 0 & 1.37 & 1.54 & 0 & 1.54 \\
\hline 02040102 & 0 & 0 & 0 & 0 & 0 & 0 \\
\hline 02040104 & 0 & 0 & 0 & 0 & 0 & 0 \\
\hline \multicolumn{7}{|c|}{ Pennsylvania } \\
\hline 02040106 & 10.5 & 6.75 & 17.2 & 11.8 & 7.57 & 19.3 \\
\hline 02040201 & 0.06 & 39.3 & 39.4 & 0.07 & 44.0 & 44.1 \\
\hline 02040202 & 0.11 & 87.4 & 87.5 & 0.12 & 98.0 & 98.1 \\
\hline 02040203 & 5.99 & 54.2 & 60.2 & 6.71 & 60.8 & 67.5 \\
\hline 02040205 & 0.20 & 2.68 & 2.88 & 0.22 & 3.00 & 3.23 \\
\hline
\end{tabular}

\footnotetext{
${ }^{1}$ Includes $10.6 \mathrm{Mgal} / \mathrm{d}$ of saline surface water.
} 

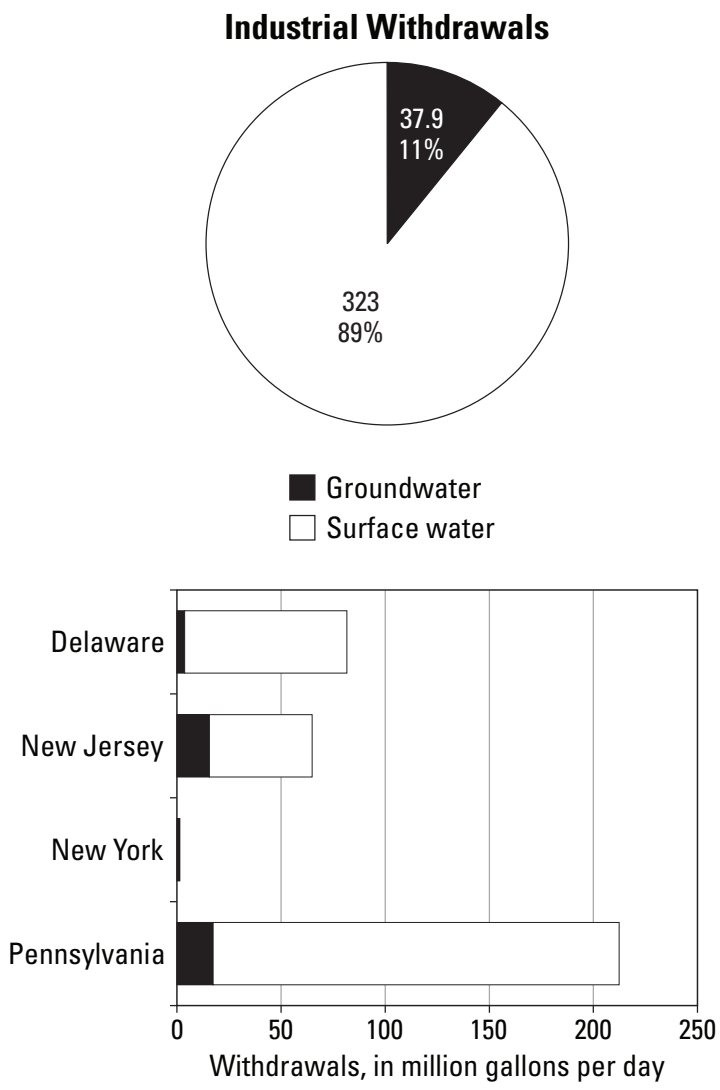

Figure 20. Distribution of industrial water withdrawals by source and state in the Delaware River Basin, 2010. (\%, percent)

\section{Commercial}

Total water withdrawals in the DRB for the commercial category were $5.89 \mathrm{Mgal} / \mathrm{d}$ (table 17), or 6.60 thousand acre-ft/ $\mathrm{yr}$ in 2010 . Approximately 74 percent $(4.35 \mathrm{Mgal} / \mathrm{d})$ of water withdrawn for commercial uses in the DRB was from groundwater sources; the other 26 percent $(1.54 \mathrm{Mgal} / \mathrm{d})$ was from surface-water sources (fig. 22). Commercial use represents less than 1 percent of total freshwater withdrawals and also less than 1 percent of all withdrawals not including thermoelectric power. Water withdrawals for commercial use were not reported for Delaware or New York, so no data were available for this category for those states.

Subbasin 02040206 had the largest water withdrawals for commercial use and accounted for 42 percent $(2.45 \mathrm{Mgal} / \mathrm{d})$ of the commercial water withdrawn in the DRB (fig. 23); all of these withdrawals were from groundwater sources, the majority of which came from a single facility in subwatershed
020402060103. Three subbasins (02040202, 02040104, and $02040106)$ accounted for another 44 percent $(2.62 \mathrm{Mgal} / \mathrm{d})$ of commercial groundwater withdrawals. The largest amount of surface water $(0.59 \mathrm{Mgal} / \mathrm{d})$ was withdrawn in subwatershed 020401040803, in the Pocono Mountains region of Pennsylvania.

Reported water withdrawals for commercial uses were largest in New Jersey (3.85 Mgal/d; 66 percent of the total withdrawals for the commercial category), where withdrawals from groundwater sources (3.54 Mgal/d) far exceeded withdrawals from surface-water sources (0.31 Mgal/d) (fig. 22). Water withdrawals for commercial uses in Pennsylvania were reported to be from 60 percent $(1.23 \mathrm{Mgal} / \mathrm{d})$ surface-water sources and 40 percent groundwater sources $(0.81 \mathrm{Mgal} / \mathrm{d})$.

\section{Mining}

Total water withdrawals in the DRB for the mining category were $41.3 \mathrm{Mgal} / \mathrm{d}$ (table 18 ), or 46.3 thousand acre-ft/yr in 2010 . Approximately 79 percent $(32.6 \mathrm{Mgal} / \mathrm{d})$ of water withdrawn for mining in the DRB was from surface-water sources; the other 21 percent $(8.78 \mathrm{Mgal} / \mathrm{d})$ was from groundwater sources (fig. 24). Mining represents 1 percent of total freshwater withdrawals and only 2 percent of all withdrawals not including thermoelectric power.

The subbasin with the largest water withdrawals for mining (02040206) accounted for 79 percent (32.6 Mgal/d) of the mining water withdrawn in the DRB (fig. 25) and can be attributed to sand and gravel mining operations. The same subbasin had mining surface-water withdrawals that accounted for 78 percent $(32.3 \mathrm{Mgal} / \mathrm{d})$ of the total mining withdrawals for the DRB. The majority of mining withdrawals $(25.2 \mathrm{Mgal} / \mathrm{d})$ were in subwatershed 020402060605 . Three subbasins (02040203, 02040105, and 02040201) accounted for another 19 percent $(7.92 \mathrm{Mgal} / \mathrm{d})$ of mining withdrawals and were almost exclusively from groundwater sources. Two subwatersheds collectively accounted for 57 percent of the total groundwater withdrawals for mining in the DRB, 020402030204 (2.67 Mgal/d) and 020401050908 (2.36 Mgal/d). No withdrawals were reported for mining purposes in subbasins 02040101, 02040103, 02040205, and 02040207.

Almost all (80 percent, $32.9 \mathrm{Mgal} / \mathrm{d})$ of the water withdrawn for mining was withdrawn in New Jersey; 20 percent (8.25 Mgal/d) in Pennsylvania, and less than 1 percent in New York (fig. 24). No withdrawals were reported for mining purposes in Delaware. Withdrawals in New Jersey were reported to be almost exclusively from surface-water sources whereas those in Pennsylvania were almost exclusively from groundwater sources. 

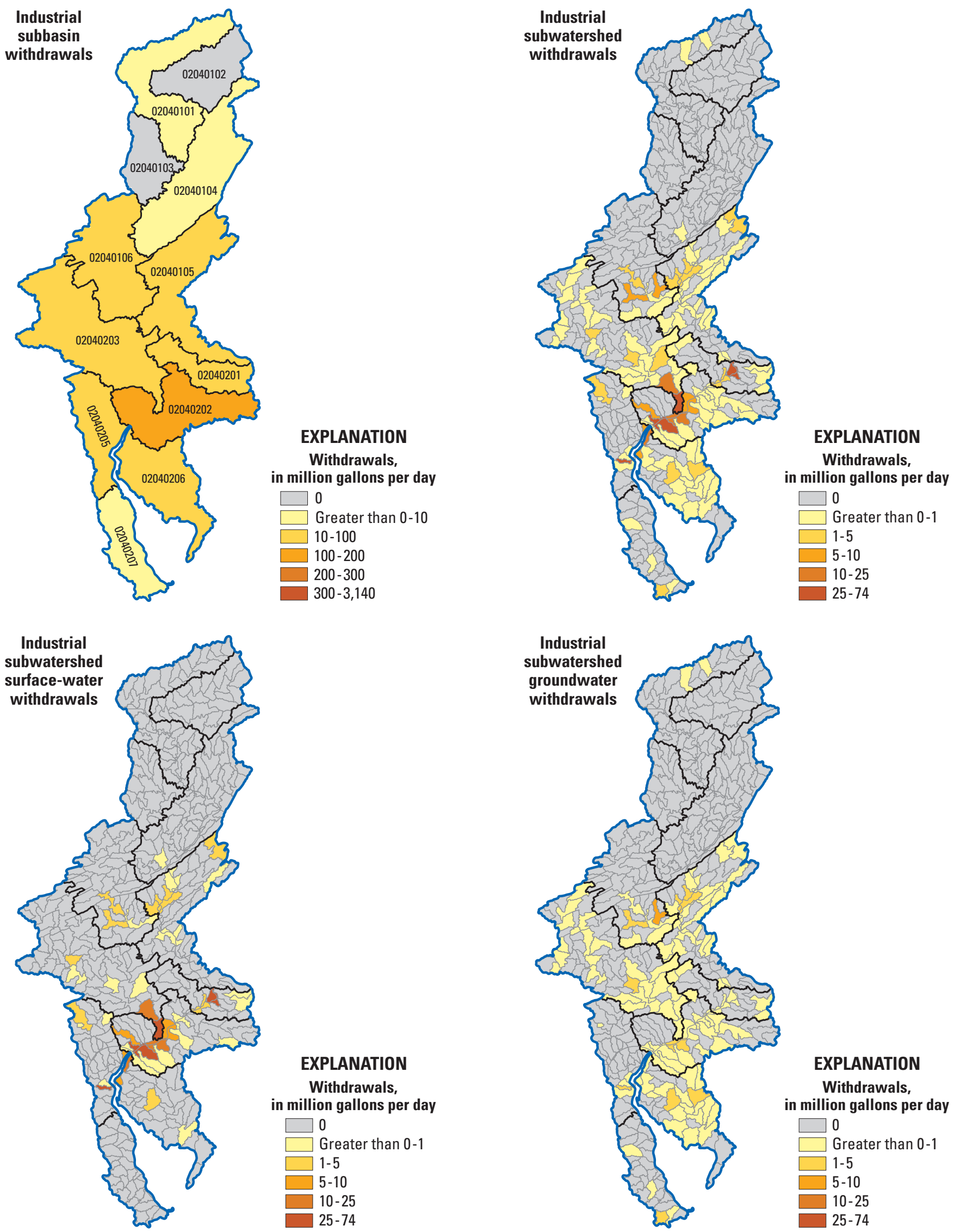

\section{EXPLANATION}

Withdrawals,

in million gallons per day
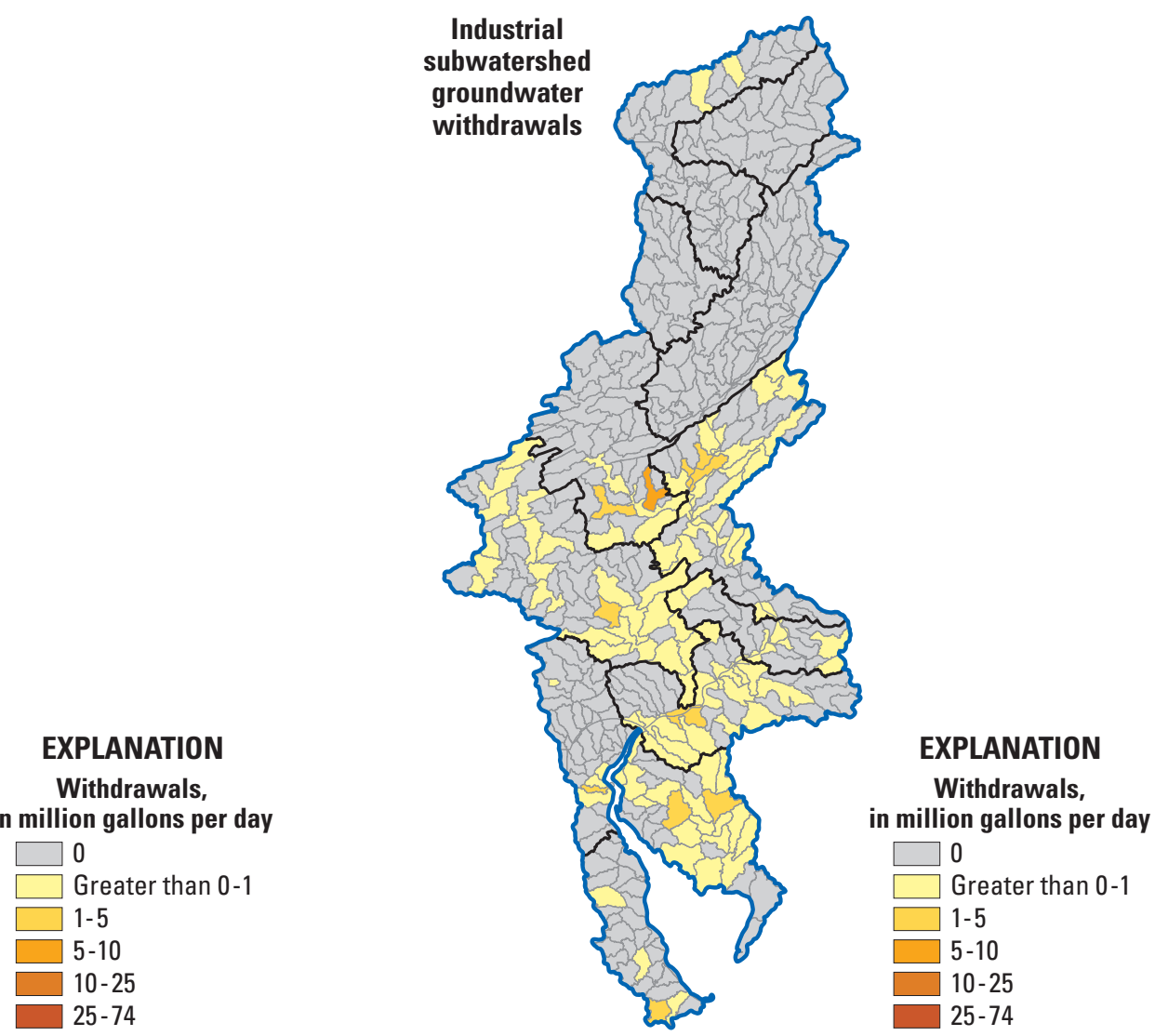

Figure 21. Industrial water withdrawals by source, subbasin, and subwatershed in the Delaware River Basin, 2010. 
Table 17. Commercial water withdrawals, Delaware River Basin, 2010.

[No withdrawals were reported for commercial purposes in Delaware and New York. Values may not sum to totals because of independent rounding.]

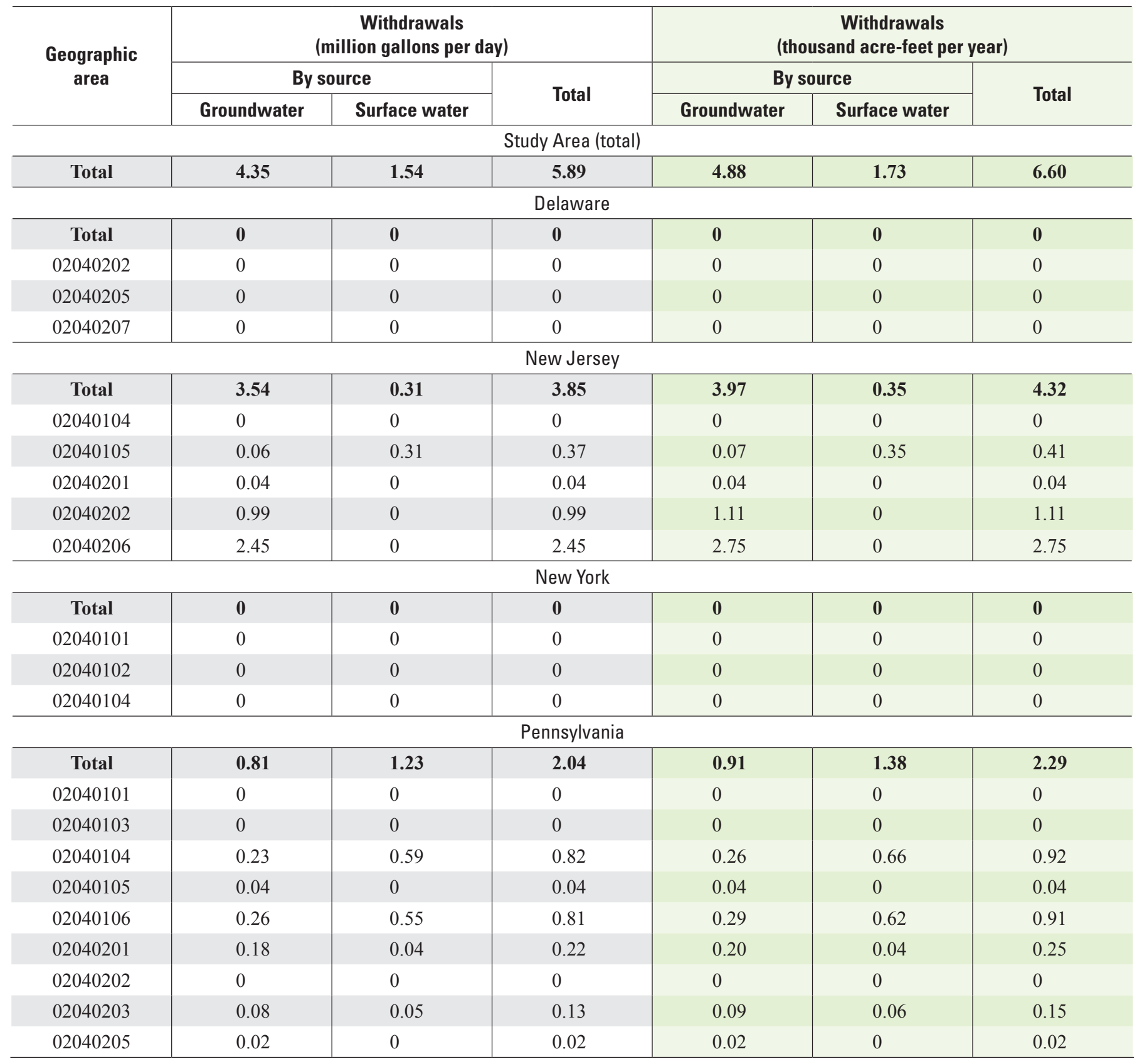




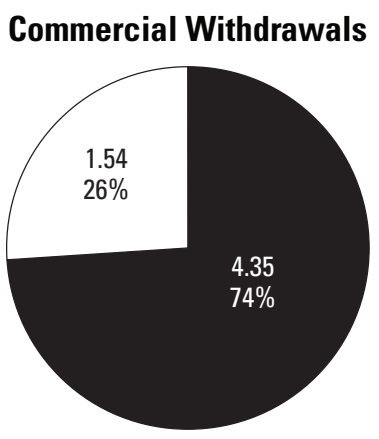

Groundwater $\square$ Surface water

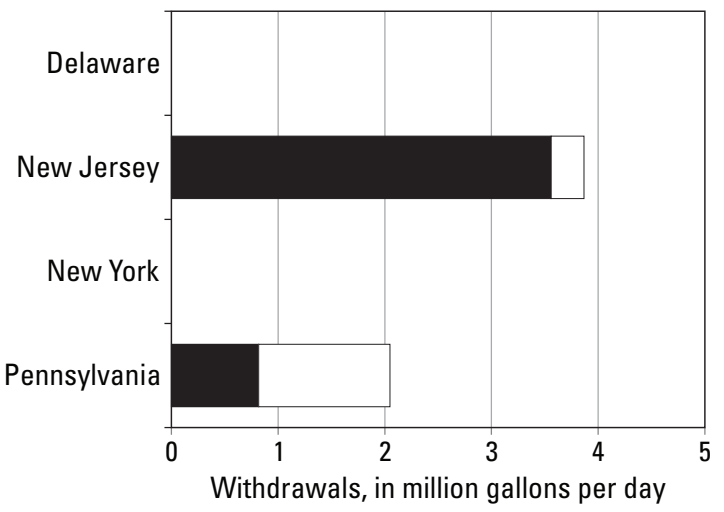

Figure 22. Distribution of commercial water withdrawals by source and state in the Delaware River Basin, 2010. (\%, percent) 

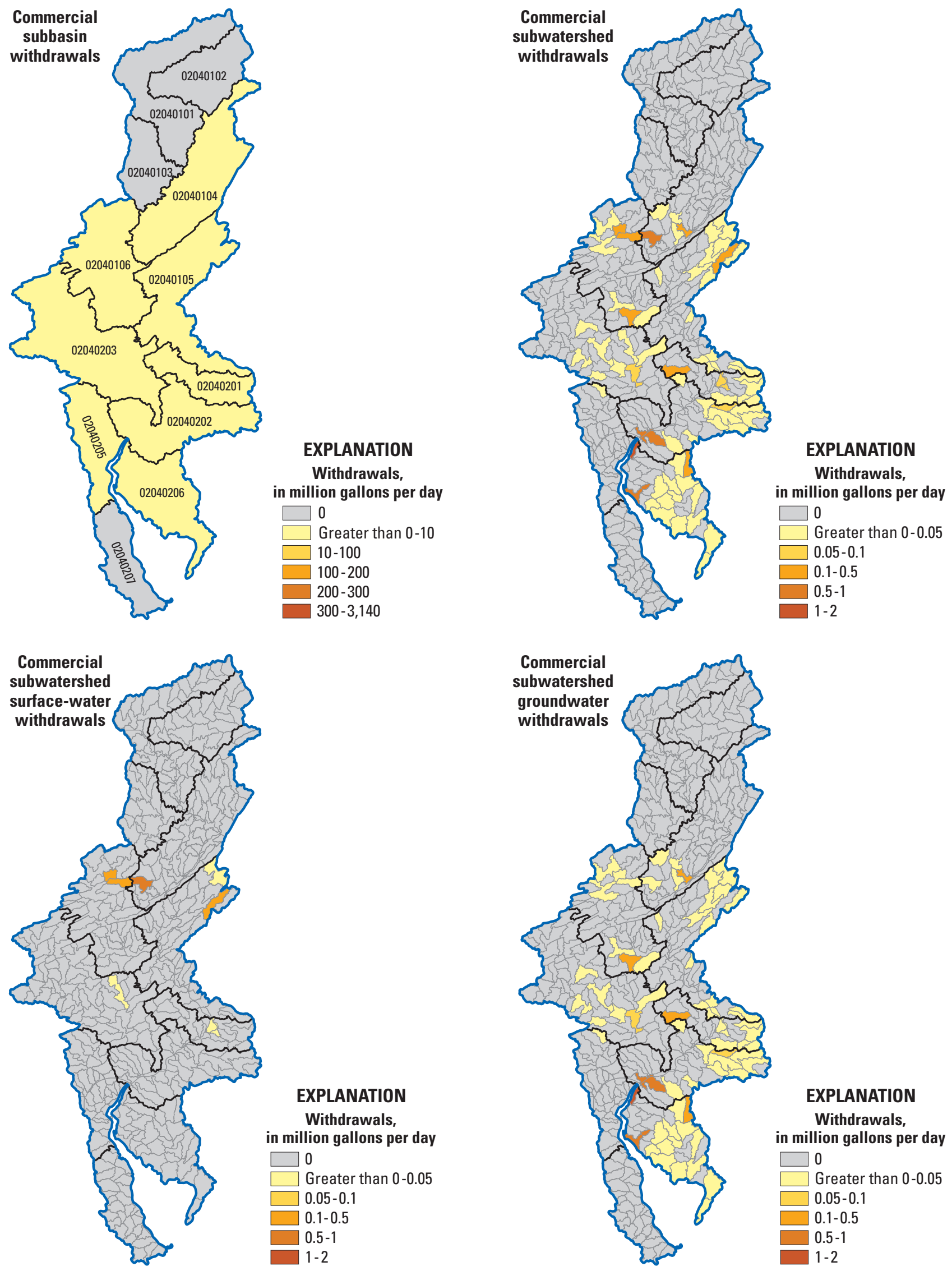

Figure 23. Commercial water withdrawals by source, subbasin, and subwatershed in the Delaware River Basin, 2010. 
Table 18. Mining water withdrawals, Delaware River Basin, 2010.

[No withdrawals were reported for mining purposes in Delaware. Values may not sum to totals because of independent rounding.]

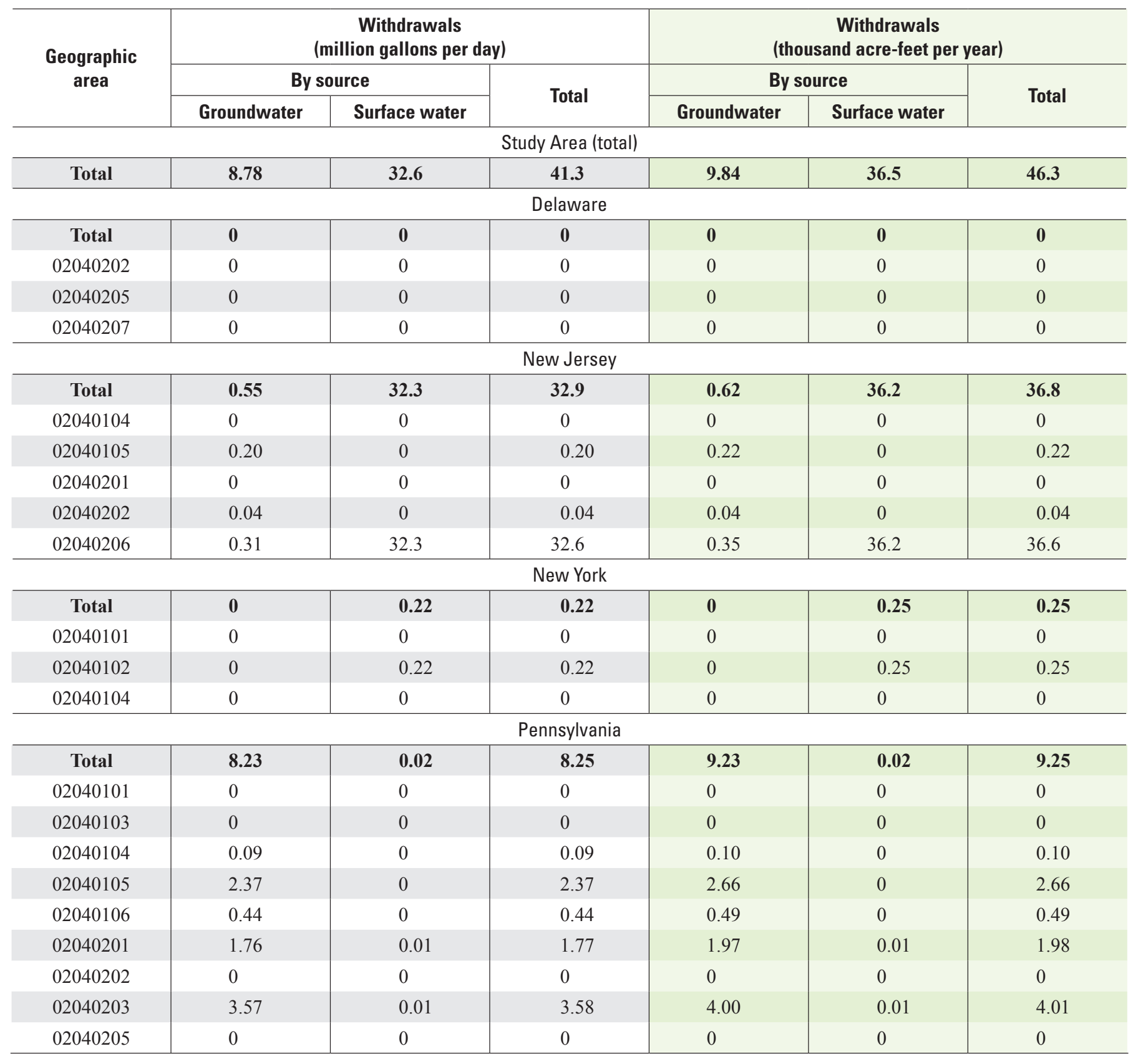




\section{Mining Withdrawals}

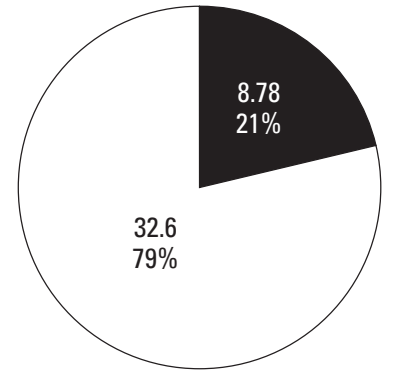

Groundwater

$\square$ Surface water

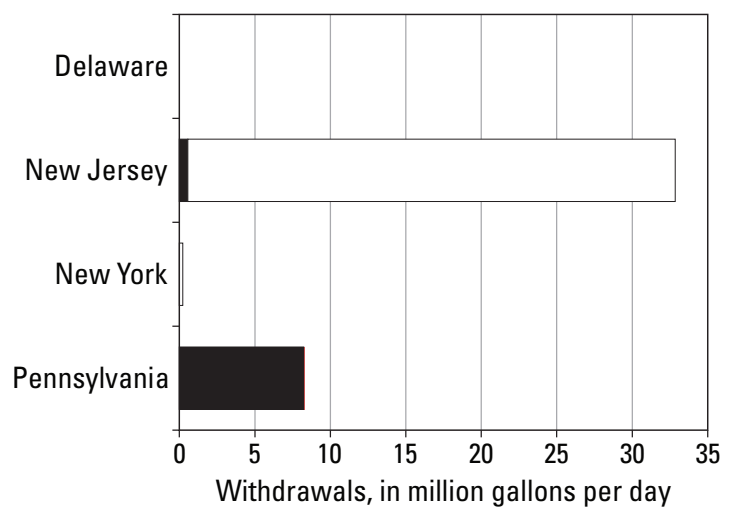

Figure 24. Distribution of mining water withdrawals by source and state in the Delaware River Basin, 2010. (\%, percent) 


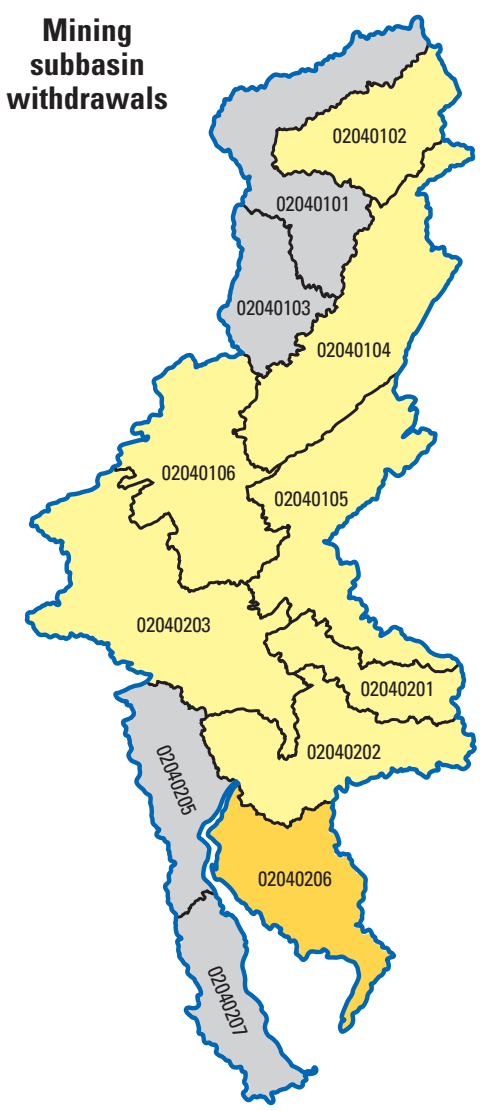

EXPLANATION

Withdrawals, in million gallons per day
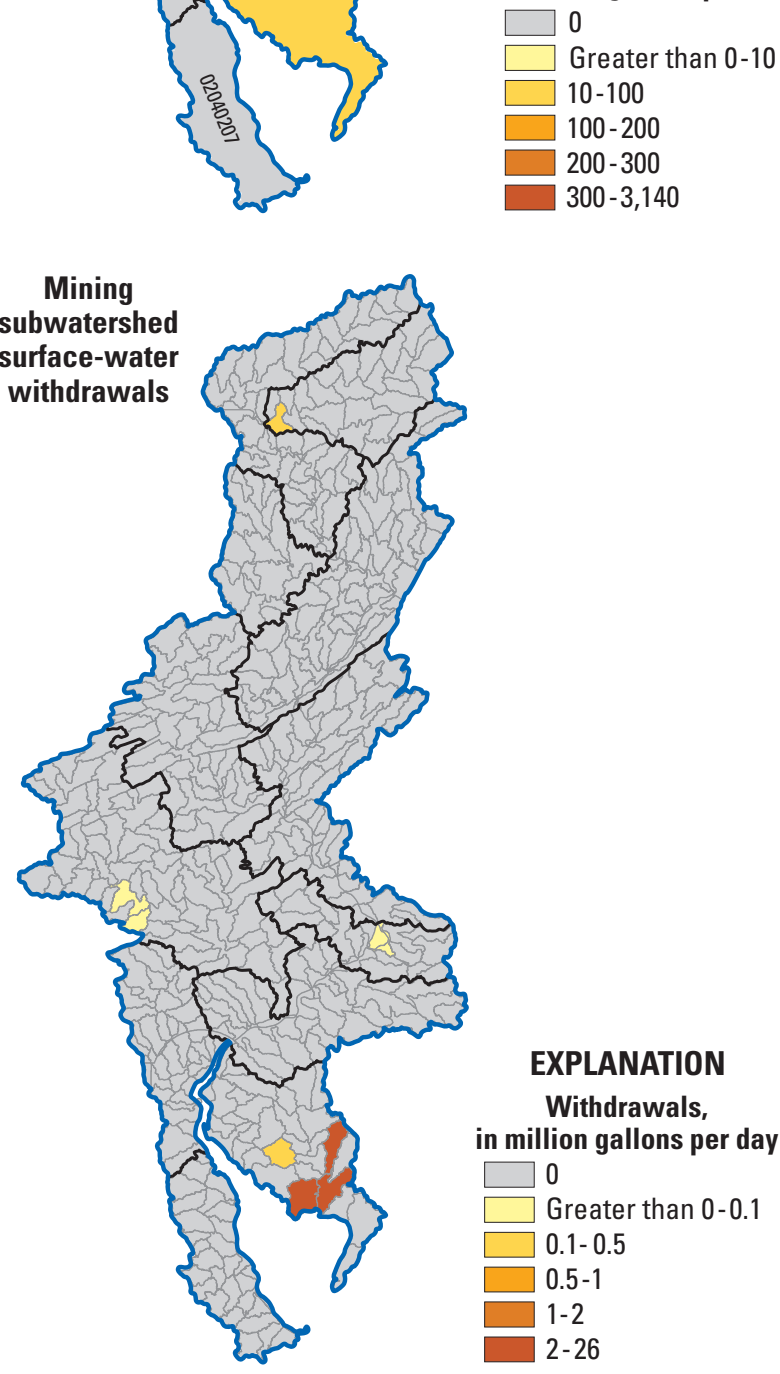

\section{EXPLANATION}

Withdrawals, in million gallons per day

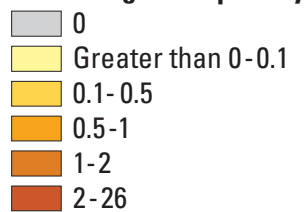

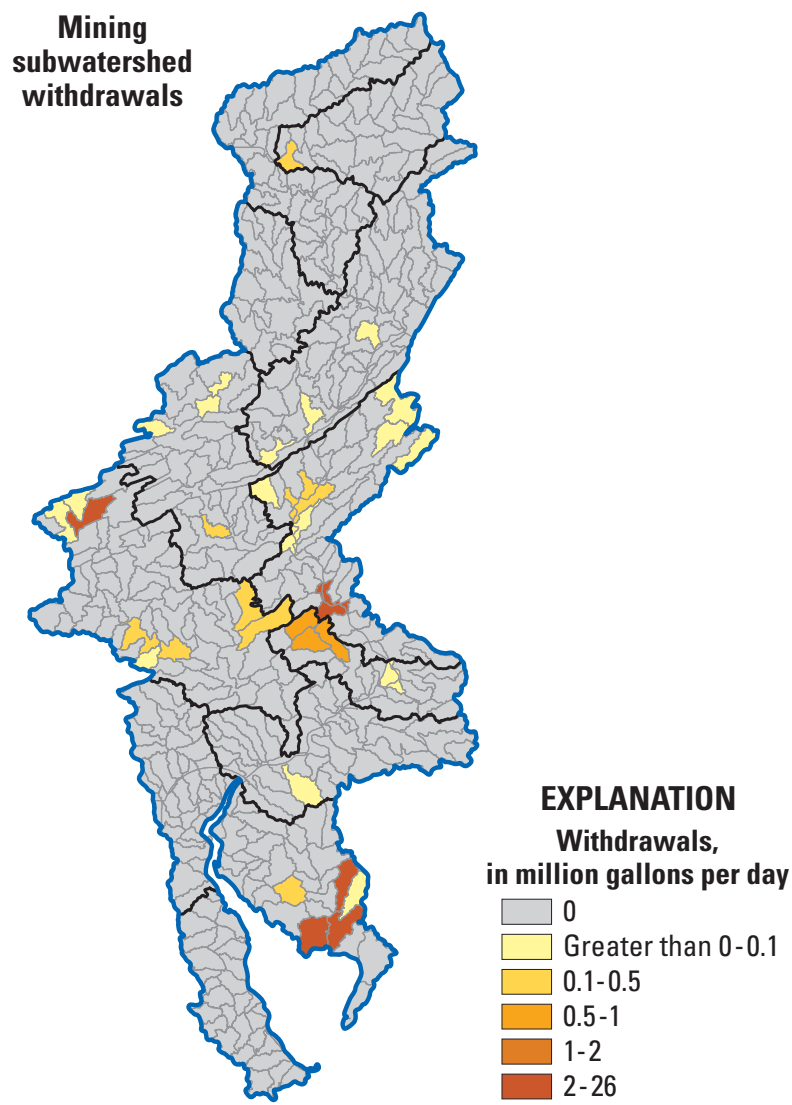

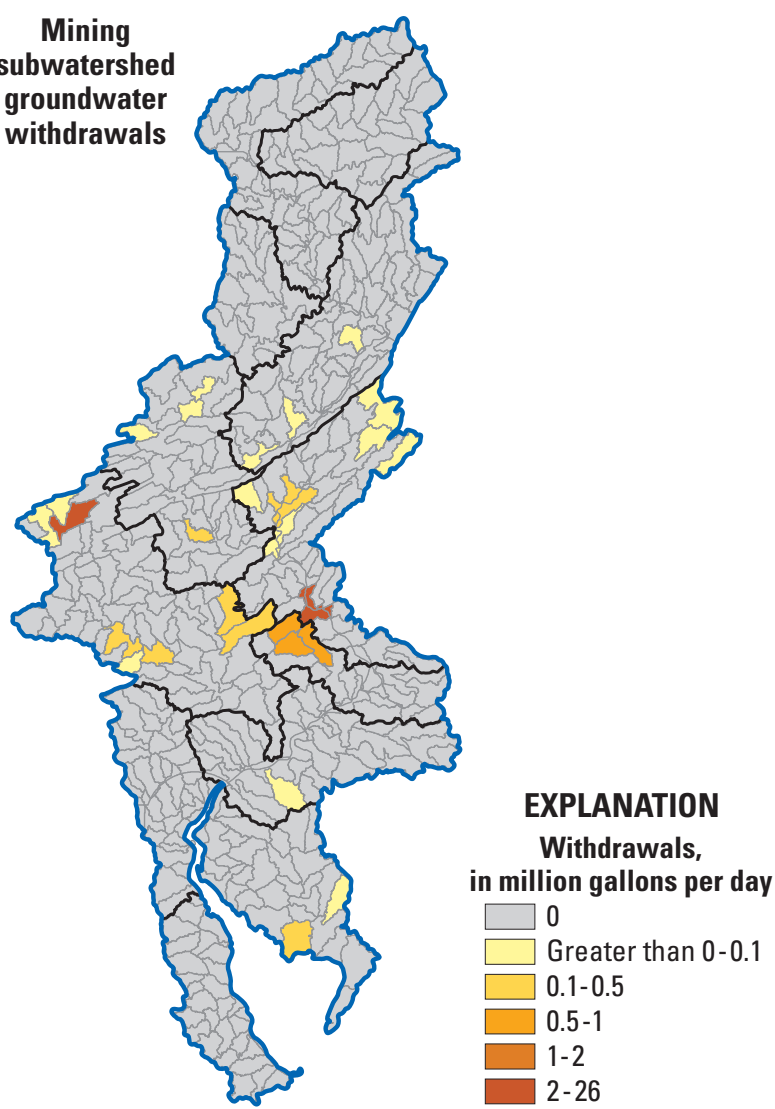

Figure 25. Mining water withdrawals by source, subbasin, and subwatershed in the Delaware River Basin, 2010. 


\section{Agricultural Sector}

The Agricultural sector consists of the irrigation, livestock, and aquaculture categories. Total withdrawals of $201 \mathrm{Mgal} / \mathrm{d}$ for the Agricultural sector represented 5 percent of the total freshwater withdrawals in the DRB in 2010 (table 19). Sixty percent (121 Mgal/d) of the water withdrawn was from groundwater sources; 40 percent $(79.9 \mathrm{Mgal} / \mathrm{d})$ was from surface-water sources (fig. 26a). Sector withdrawals are dominated by irrigation withdrawals in the Coastal Plain Physiographic Province in New Jersey and Delaware. Irrigation withdrawals ( $175 \mathrm{Mgal} / \mathrm{d})$ accounted for 87 percent of the water withdrawals for this sector, aquaculture water withdrawals (19.3 Mgal/d) accounted for 10 percent, and livestock water withdrawals $(6.72 \mathrm{Mgal} / \mathrm{d})$ accounted for the remaining 3 percent.

The Lower basin (020402) accounted for 79 percent (158 Mgal/d) of the total Agricultural sector withdrawals, whereas the Upper basin (020401) accounted for 21 percent (42.6 Mgal/d) (fig. 26b). The Lower basin water withdrawals were about two-thirds from groundwater sources (105 Mgal/d of groundwater, $53.4 \mathrm{Mgal} / \mathrm{d}$ of surface water) and used primarily for irrigation. The Upper basin withdrawals were about two-thirds from surface-water sources $(26.5 \mathrm{Mgal} / \mathrm{d}$ of surface water and $16.2 \mathrm{Mgal} / \mathrm{d}$ of groundwater) and were used primarily for irrigation and aquaculture. The geographic distribution of total Agricultural sector water withdrawals by subbasin is shown in figure $26 \mathrm{c}$.

Table 19. Agricultural sector water withdrawals, Delaware River Basin, 2010.

[Values may not sum to totals because of independent rounding.]

\begin{tabular}{|c|c|c|c|c|c|c|c|c|c|c|c|}
\hline \multicolumn{12}{|c|}{$\begin{array}{c}\text { Withdrawals } \\
\text { (million gallons per day) }\end{array}$} \\
\hline \multicolumn{3}{|c|}{ Irrigation } & \multicolumn{3}{|c|}{ Livestock } & \multicolumn{3}{|c|}{ Aquaculture } & \multicolumn{3}{|c|}{ Total } \\
\hline \multicolumn{12}{|c|}{ Study Area (total) } \\
\hline 3.18 & 22.1 & 25.2 & 1.19 & 0.12 & 1.31 & 11.8 & 4.28 & 16.1 & 16.2 & 26.5 & 42.6 \\
\hline \multicolumn{12}{|c|}{ Lower Delaware River Basin (total) } \\
\hline 99.4 & 50.2 & 150 & 4.89 & 0.52 & 5.41 & 0.47 & 2.71 & 3.18 & 105 & 53.4 & 158 \\
\hline
\end{tabular}




\section{A Agricultural Sector Withdrawals}

Upper Delaware

Basin

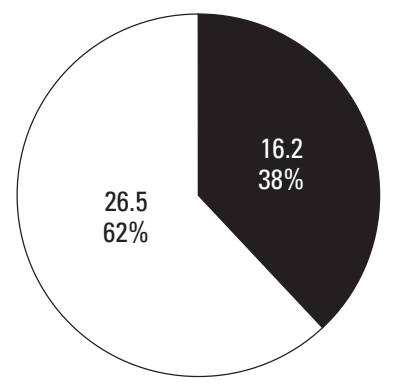

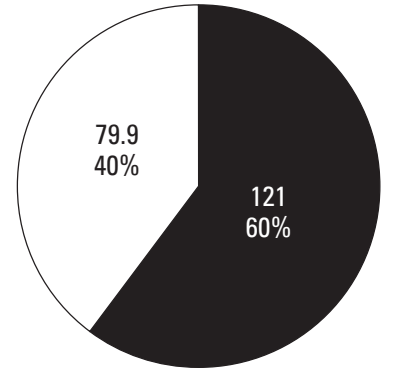

Lower Delaware

Basin

Groundwater

$\square$ Surface water
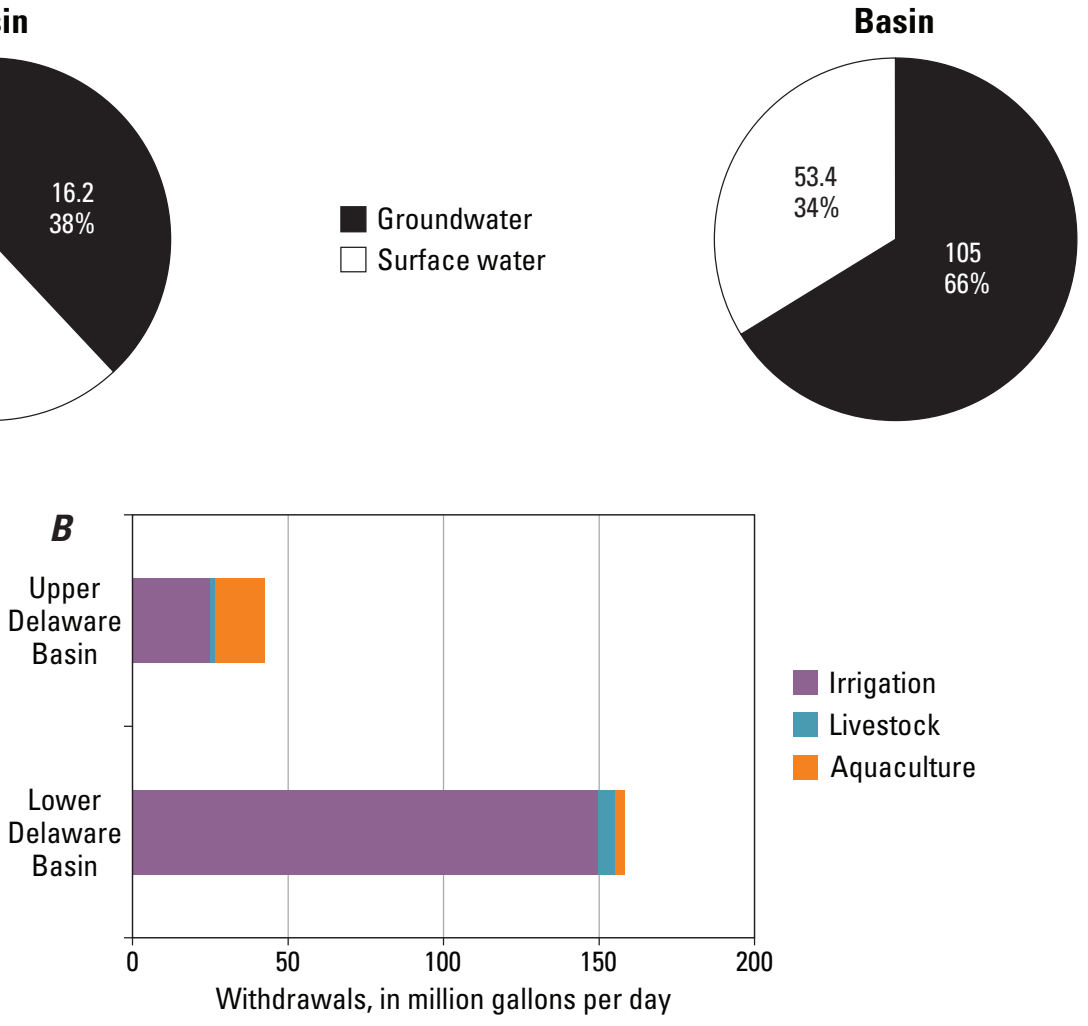

Figure 26. Distribution of water withdrawals for the Agricultural sector in the Delaware River Basin, 2010 by $A$, source and basin, $B$, basin and water use category, and $C$, subbasin and source. (\%, percent) 

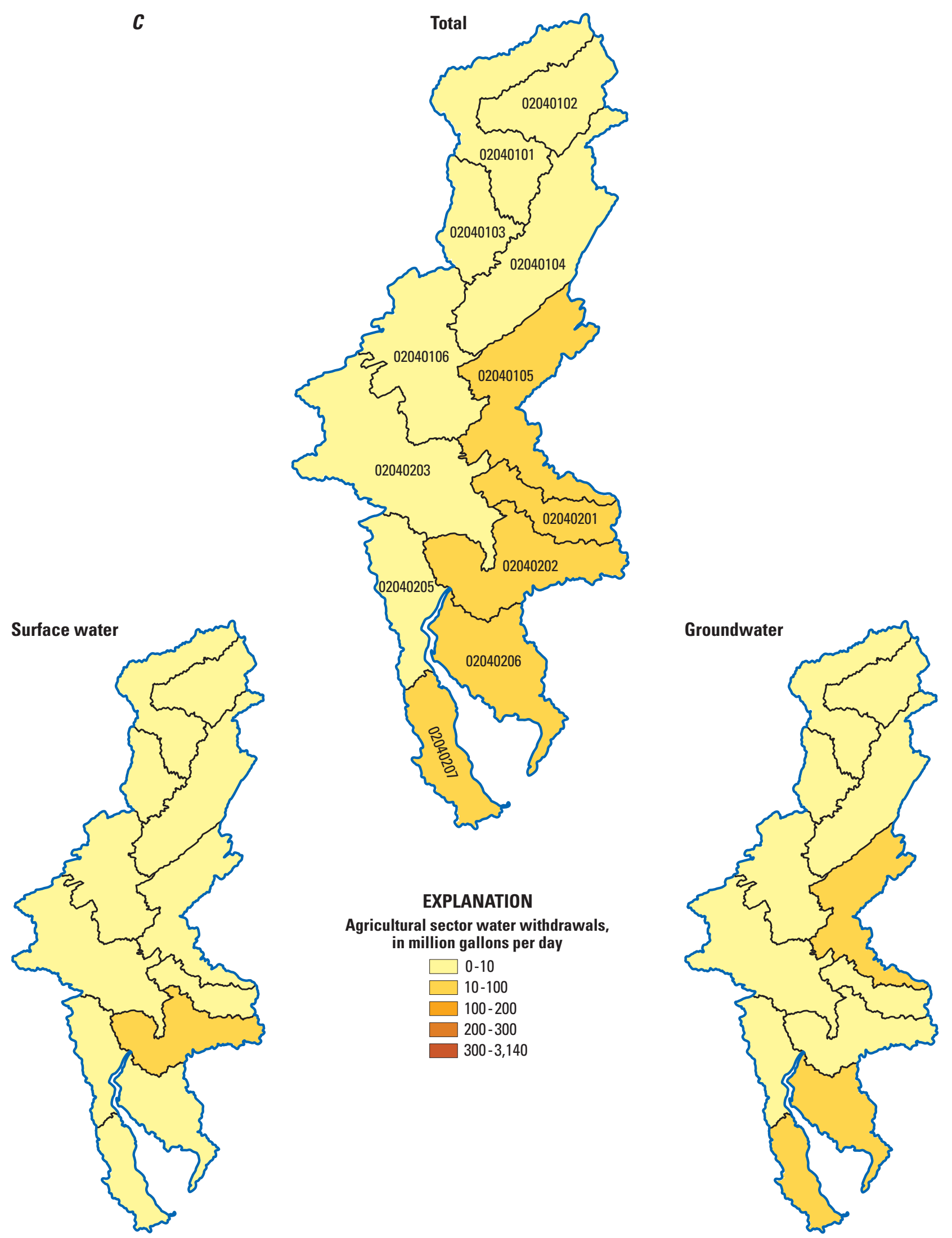

Figure 26. Distribution of water withdrawals for the Agricultural sector in the Delaware River Basin, 2010 by $A$, source and basin, $B$, basin and water use category, and $C$, subbasin and source. (\%, percent)-Continued 
Irrigation

Total water withdrawals in the DRB for the irrigation category were $175 \mathrm{Mgal} / \mathrm{d}$ (table 20), or 196 thousand acre$\mathrm{ft} / \mathrm{yr}$ in 2010. Irrigation represents about 4 percent of total freshwater withdrawals and about 8 percent of all withdrawals not including thermoelectric power. Approximately 59 percent (103 Mgal/d) was from groundwater; the other 41 percent (72.3 Mgal/d) of water withdrawn for irrigation in the DRB was from surface-water sources, such as reservoirs, lakes, and streams (fig. 27). Calculations of water withdrawals based on areal estimates of crop irrigation accounted for 42 percent (73.3 Mgal/d) of total category withdrawals.

The subbasins with the largest water withdrawals for irrigation (02040207, 02040206, and 02040202) were located primarily in the Coastal Plain in the southeastern part of the DRB (fig. 28). These subbasins accounted for almost three-quarters (129 Mgal/d) of the irrigation water withdrawn. Two subbasins

Table 20. Irrigation water withdrawals, Delaware River Basin, 2010.

[Values may not sum to totals because of independent rounding.]

\begin{tabular}{|c|c|c|c|c|c|c|}
\hline \multirow{3}{*}{$\begin{array}{l}\text { Geographic } \\
\text { area }\end{array}$} & \multicolumn{3}{|c|}{$\begin{array}{c}\text { Withdrawals } \\
\text { (million gallons per day) }\end{array}$} & \multicolumn{3}{|c|}{$\begin{array}{c}\text { Withdrawals } \\
\text { (thousand acre-feet per year) }\end{array}$} \\
\hline & \multicolumn{2}{|c|}{ By source } & \multirow{2}{*}{ Total } & \multicolumn{2}{|c|}{ By source } & \multirow{2}{*}{ Total } \\
\hline & Groundwater & Surface water & & Groundwater & Surface water & \\
\hline \multicolumn{7}{|c|}{ Study Area (total) } \\
\hline Total & 103 & 72.3 & 175 & 115 & 81.0 & 196 \\
\hline \multicolumn{7}{|c|}{ Delaware } \\
\hline Total & 57.3 & 10.1 & 67.5 & 64.3 & 11.3 & 75.6 \\
\hline 02040202 & 0.01 & 0 & 0.01 & 0.01 & 0 & 0.01 \\
\hline 02040205 & 3.38 & 0.71 & 4.09 & 3.79 & 0.80 & 4.58 \\
\hline 02040207 & 54.0 & 9.41 & 63.4 & 60.5 & 10.5 & 71.0 \\
\hline \multicolumn{7}{|c|}{ New Jersey } \\
\hline Total & 38.0 & 39.5 & 77.6 & 42.7 & 44.3 & 86.9 \\
\hline 02040104 & 0 & 0.02 & 0.02 & 0 & 0.02 & 0.02 \\
\hline 02040105 & 0.69 & 1.29 & 1.98 & 0.77 & 1.45 & 2.22 \\
\hline 02040201 & 0.84 & 9.66 & 10.5 & 0.94 & 10.8 & 11.8 \\
\hline 02040202 & 4.21 & 21.8 & 26.0 & 4.72 & 24.4 & 29.2 \\
\hline 02040206 & 32.3 & 6.74 & 39.0 & 36.2 & 7.56 & 43.8 \\
\hline \multicolumn{7}{|c|}{ New York } \\
\hline Total & 0.19 & 19.9 & 20.1 & 0.21 & 22.3 & 22.5 \\
\hline 02040101 & 0.06 & 6.85 & 6.91 & 0.07 & 7.68 & 7.75 \\
\hline 02040102 & 0.03 & 3.55 & 3.58 & 0.03 & 3.98 & 4.01 \\
\hline 02040104 & 0.10 & 9.52 & 9.62 & 0.11 & 10.7 & 10.8 \\
\hline \multicolumn{7}{|c|}{ Pennsylvania } \\
\hline Total & 7.04 & 2.71 & 9.75 & 7.89 & 3.04 & 10.9 \\
\hline 02040101 & 0.06 & 0 & 0.06 & 0.07 & 0 & 0.07 \\
\hline 02040103 & 0.11 & 0 & 0.11 & 0.12 & 0 & 0.12 \\
\hline 02040104 & 0.03 & 0.04 & 0.07 & 0.03 & 0.04 & 0.08 \\
\hline 02040105 & 0.77 & 0.24 & 1.01 & 0.86 & 0.27 & 1.13 \\
\hline 02040106 & 1.33 & 0.55 & 1.88 & 1.49 & 0.62 & 2.11 \\
\hline 02040201 & 0.52 & 0.21 & 0.73 & 0.58 & 0.24 & 0.82 \\
\hline 02040202 & 0.30 & 0.01 & 0.31 & 0.34 & 0.01 & 0.35 \\
\hline 02040203 & 3.07 & 1.21 & 4.28 & 3.44 & 1.36 & 4.80 \\
\hline 02040205 & 0.85 & 0.45 & 1.30 & 0.95 & 0.50 & 1.46 \\
\hline
\end{tabular}


in the Coastal Plain (02040206 and 02040207) had irrigation groundwater withdrawals that accounted for 84 percent

(86.3 Mgal/d) of the total irrigation groundwater withdrawals for the DRB; one subbasin (02040202) accounted for 30 percent (21.8 Mgal/d) of irrigation surface-water withdrawals. The subwatersheds with the largest groundwater and surfacewater withdrawals were also located in the Coastal Plain region of New Jersey and Delaware.
Eighty-three percent (145 Mgal/d) of the water withdrawn for irrigation was withdrawn in New Jersey and Delaware (fig. 27). Irrigation withdrawals were mostly from groundwater sources in Delaware (85 percent groundwater) and Pennsylvania (72 percent groundwater); in New Jersey, they were split equally ( 49 percent groundwater, 51 percent surface water) between groundwater and surface-water sources; and in New York, they were almost exclusively (99 percent) surface water.

\section{Irrigation Withdrawals}

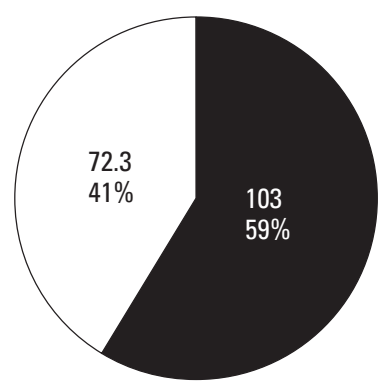

Groundwater

$\square$ Surface water

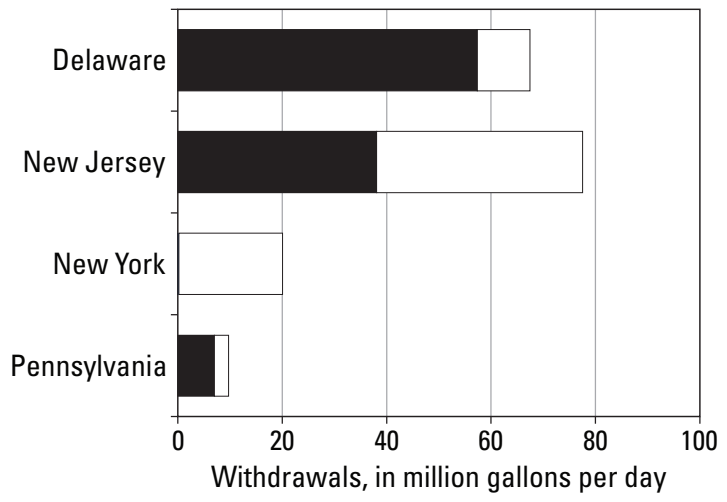

Figure 27. Distribution of irrigation water withdrawals by source and state in the Delaware River Basin, 2010. (\%, percent) 


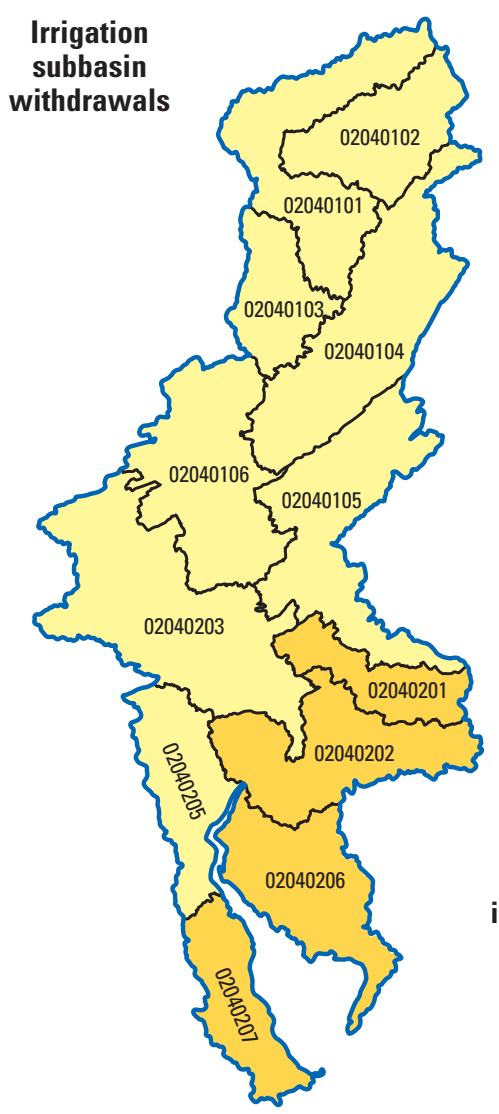

\section{EXPLANATION \\ Withdrawals in million gallons per day

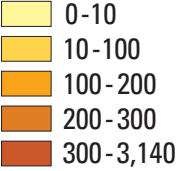

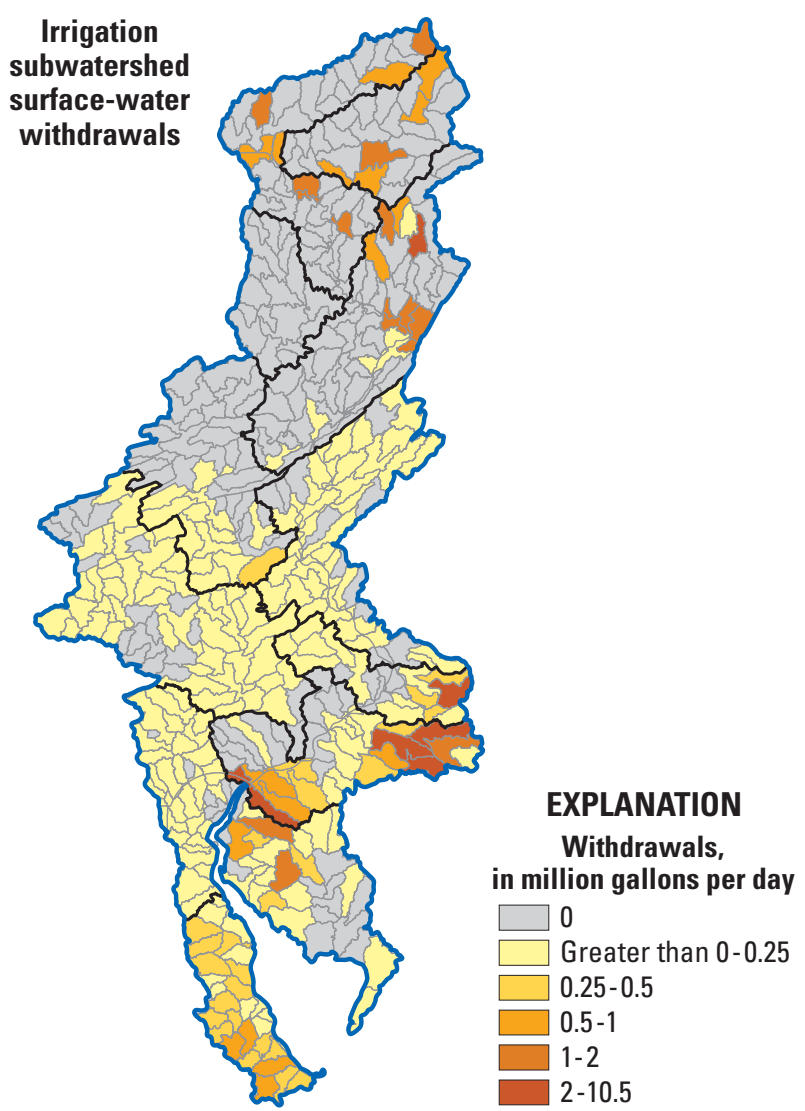

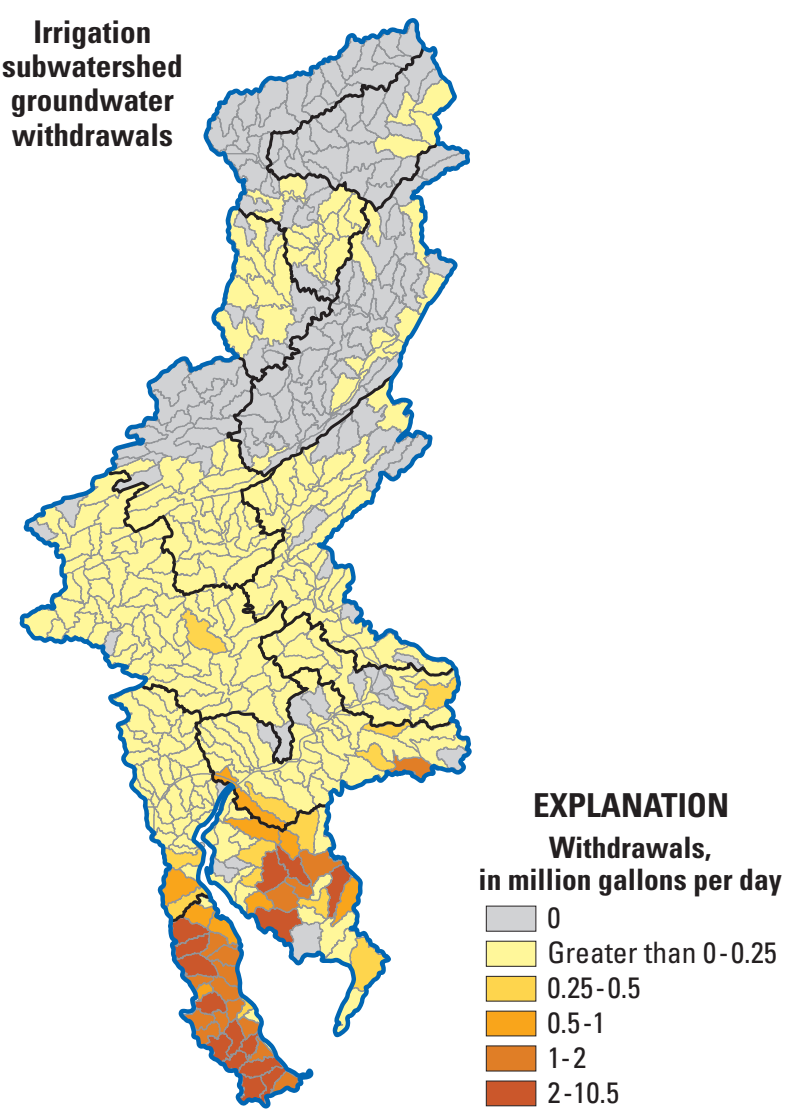

Figure 28. Irrigation water withdrawals by source, subbasin, and subwatershed in the Delaware River Basin, 2010. 


\section{Livestock}

Total water withdrawals in the DRB for the livestock category were $6.72 \mathrm{Mgal} / \mathrm{d}$ (table 21), or 7.53 thousand acre-ft/yr in 2010. Livestock represents less than 1 percent of total freshwater withdrawals and less than 1 percent of all withdrawals not including thermoelectric power. Approximately 90 percent $(6.08 \mathrm{Mgal} / \mathrm{d})$ of water withdrawn for livestock in the DRB was from groundwater sources; the other 10 percent $(0.64 \mathrm{Mgal} / \mathrm{d})$ was from surface-water sources (fig. 29). Areal estimates accounted for 85 percent (5.69 Mgal/d) of the total withdrawals for this category.

Table 21. Livestock water withdrawals, Delaware River Basin, 2010.

[Values may not sum to totals because of independent rounding.]

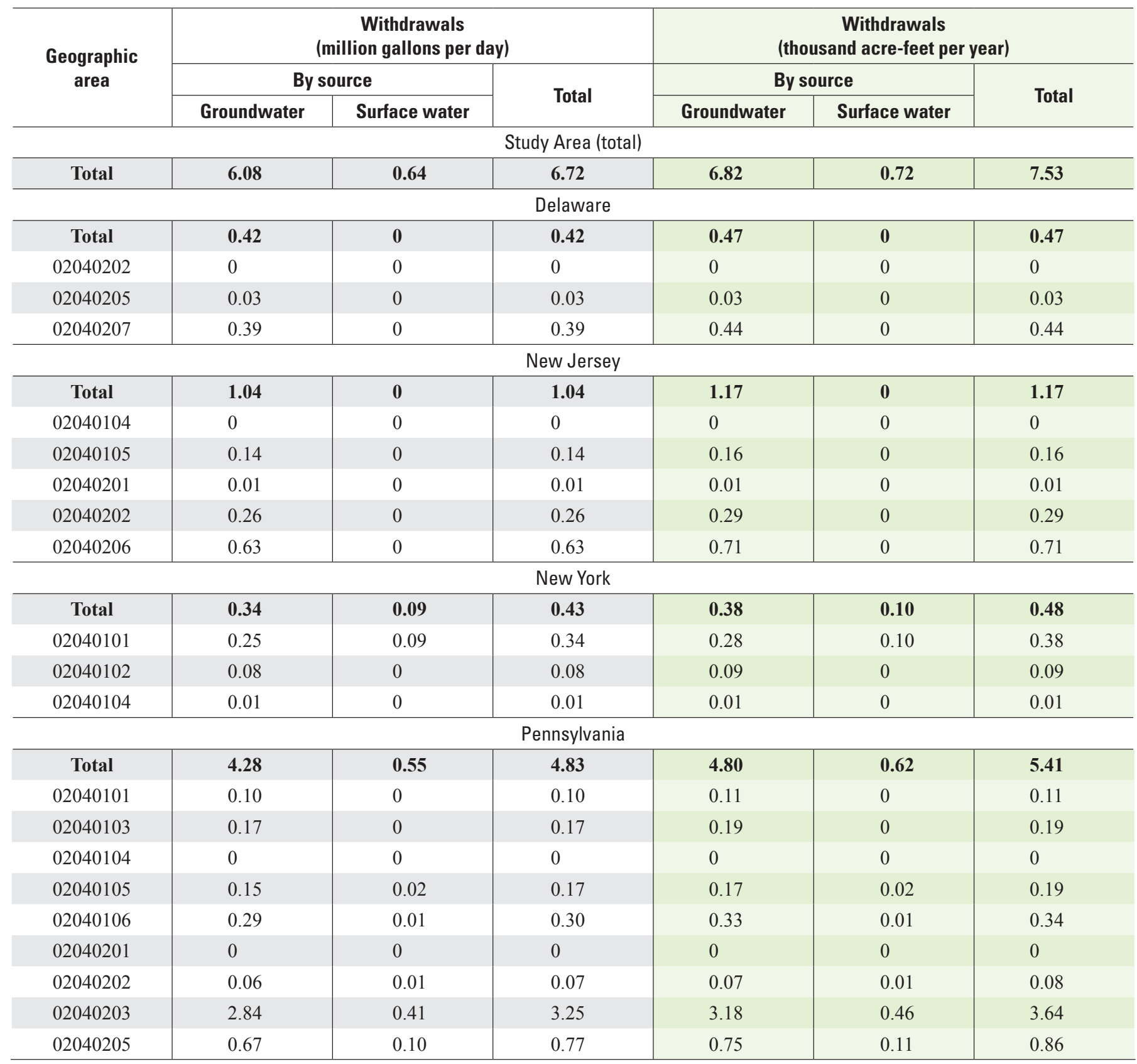


The subbasins with the largest water withdrawals for livestock (02040203, 02040205, and 02040206) accounted for 70 percent $(4.68 \mathrm{Mgal} / \mathrm{d})$ of the livestock water withdrawn (fig. 30). These three subbasins accounted for 69 percent (4.17 Mgal $/ \mathrm{d})$ of the total livestock groundwater withdrawals for the DRB; one subbasin (02040203) accounted for 64 percent $(0.41 \mathrm{Mgal} / \mathrm{d})$ of livestock surface-water withdrawals. The two subwatersheds with the largest withdrawals were $020402030402(0.23 \mathrm{Mgal} / \mathrm{d})$ in Pennsylvania and 020402060404 (0.22 Mgal/d) in New Jersey. Almost three-quarters $(4.83 \mathrm{Mgal} / \mathrm{d})$ of the water withdrawn for livestock was withdrawn in Pennsylvania; another 15 percent (1.04 Mgal/d) of the total was withdrawn in New Jersey (fig. 29).
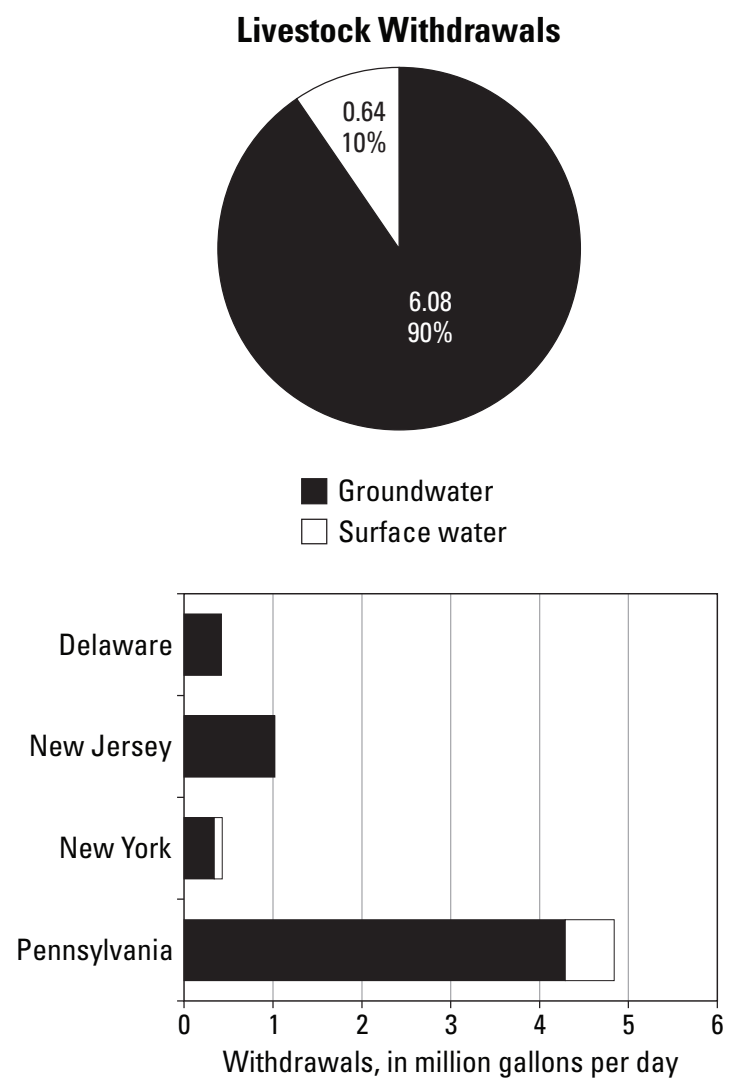

Figure 29. Distribution of livestock water withdrawals by source and state in the Delaware River Basin, 2010. (\%, percent) 


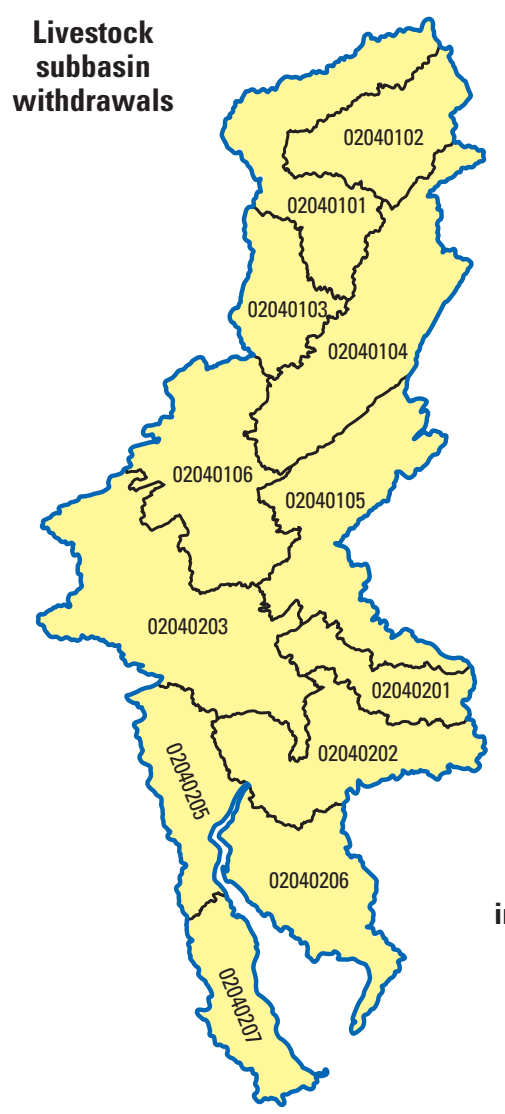

\section{EXPLANATION}

Withdrawals,

in million gallons per day
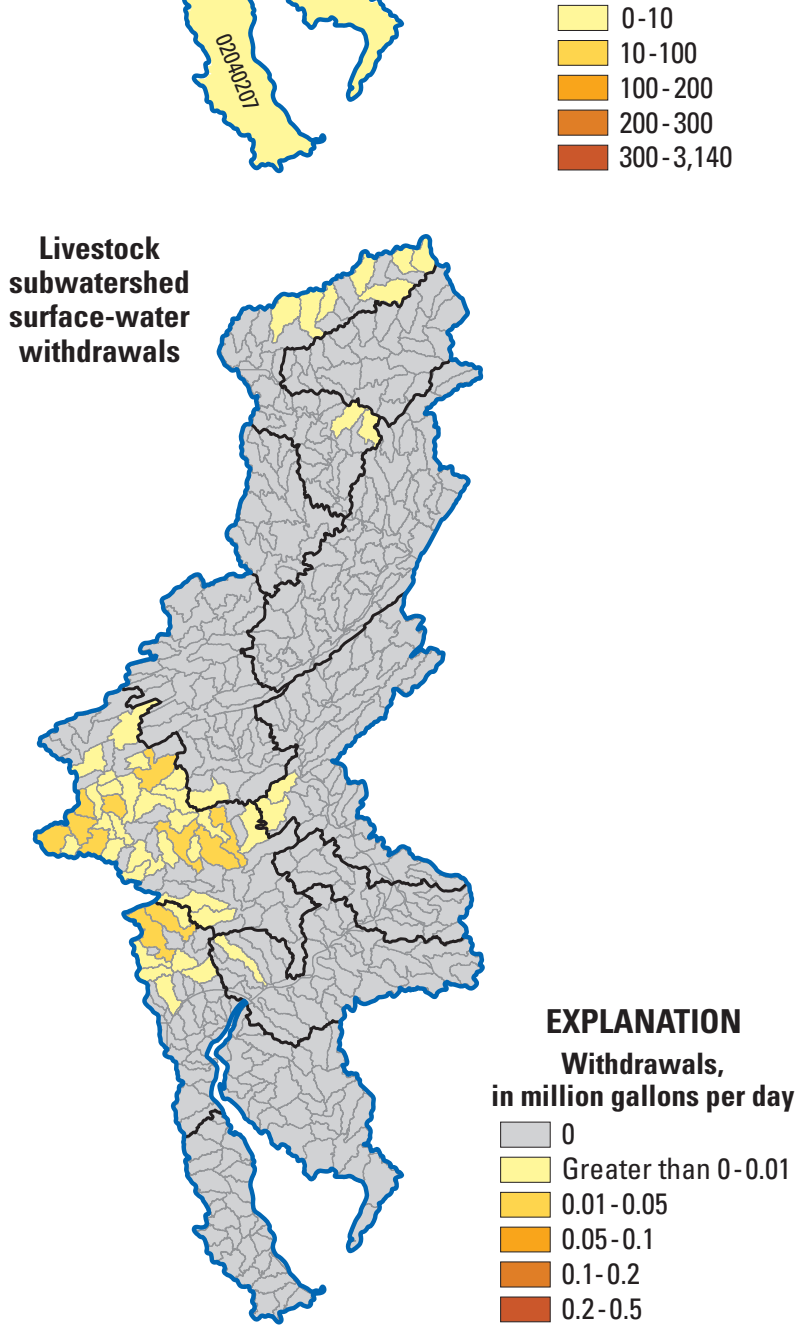
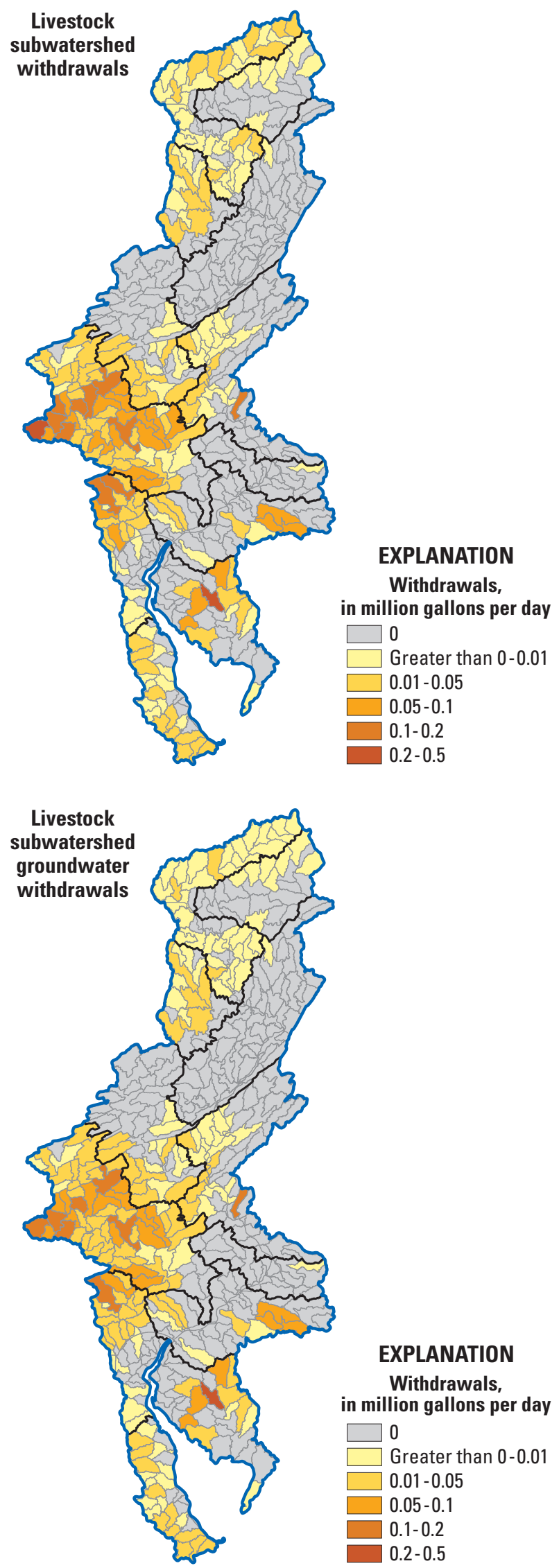

Figure 30. Livestock water withdrawals by source, subbasin, and subwatershed in the Delaware River Basin, 2010. 


\section{Aquaculture}

Total water withdrawals in the Delaware River Basin for the aquaculture category were $19.3 \mathrm{Mgal} / \mathrm{d}$ (table 22), or 21.6 thousand acre-ft/yr in 2010. Aquaculture represents less than 1 percent of total freshwater withdrawals and also less than 1 percent of all withdrawals not including thermoelectric power. Approximately 64 percent $(12.3 \mathrm{Mgal} / \mathrm{d})$ of water withdrawn for aquaculture in the DRB was from groundwater; the other 36 percent $(6.99 \mathrm{Mgal} / \mathrm{d})$ was from surface-water sources (fig. 31).

Subbasin 02040105 had the largest water withdrawals for aquaculture and accounted for almost half $(9.36 \mathrm{Mgal} / \mathrm{d})$ of the aquaculture water withdrawn in the DRB (fig. 32). One subwatershed (020401050204) in New Jersey accounted for not only almost all of this amount $(9.11 \mathrm{Mgal} / \mathrm{d})$, but also

Table 22. Aquaculture water withdrawals, Delaware River Basin, 2010.

[Values may not sum to totals because of independent rounding.]

\begin{tabular}{|c|c|c|c|c|c|c|}
\hline \multirow{2}{*}{$\begin{array}{l}\text { Geographic } \\
\text { area }\end{array}$} & \multicolumn{3}{|c|}{$\begin{array}{c}\text { Withdrawals } \\
\text { (million gallons per day) }\end{array}$} & \multicolumn{3}{|c|}{$\begin{array}{c}\text { Withdrawals } \\
\text { (thousand acre-feet per year) }\end{array}$} \\
\hline & \multicolumn{2}{|c|}{ By source } & Total & \multicolumn{2}{|c|}{ By source } & Total \\
\hline \multicolumn{7}{|c|}{ Study Area (total) } \\
\hline Total & 12.3 & 6.99 & 19.3 & 13.8 & 7.84 & 21.6 \\
\hline 02040202 & 0 & 0 & 0 & 0 & 0 & 0 \\
\hline 02040205 & 0 & 0 & 0 & 0 & 0 & 0 \\
\hline 02040207 & 0.04 & 0 & 0.04 & 0.04 & 0 & 0.04 \\
\hline \multicolumn{7}{|c|}{ New Jersey } \\
\hline 02040201 & 0 & 0 & 0 & 0 & 0 & 0 \\
\hline 02040202 & 0 & 0 & 0 & 0 & 0 & 0 \\
\hline 02040206 & 0 & 0 & 0 & 0 & 0 & 0 \\
\hline \multicolumn{7}{|c|}{ New York } \\
\hline Total & 0.43 & 2.90 & 3.33 & 0.48 & 3.25 & 3.73 \\
\hline 02040101 & 0 & 0 & 0 & 0 & 0 & 0 \\
\hline 02040102 & 0.43 & 2.90 & 3.33 & 0.48 & 3.25 & 3.73 \\
\hline 02040104 & 0 & 0 & 0 & 0 & 0 & 0 \\
\hline \multicolumn{7}{|c|}{ Pennsylvania } \\
\hline 02040106 & 2.10 & 0.20 & 2.30 & 2.35 & 0.22 & 2.58 \\
\hline 02040201 & 0 & 0 & 0 & 0 & 0 & 0 \\
\hline 02040202 & 0 & 0 & 0 & 0 & 0 & 0 \\
\hline 02040203 & 0.24 & 2.20 & 2.44 & 0.27 & 2.47 & 2.74 \\
\hline 02040205 & 0.19 & 0.51 & 0.70 & 0.21 & 0.57 & 0.78 \\
\hline
\end{tabular}


accounted for 74 percent of the total groundwater withdrawals. Two subbasins (02040102 and 02040203) accounted for 73 percent $(5.10 \mathrm{Mgal} / \mathrm{d})$ of aquaculture surface-water withdrawals, more than half $(2.90 \mathrm{Mgal} / \mathrm{d})$ of which was withdrawn in subwatershed 020401020103 in New York.

Eighty-three percent $(15.9 \mathrm{Mgal} / \mathrm{d})$ of the water withdrawn for aquaculture was withdrawn in New Jersey and Pennsylvania, and the remaining withdrawals were almost all from New York (3.33 Mgal/d) (fig. 31). All the withdrawals for aquaculture purposes in New Jersey $(9.11 \mathrm{Mgal} / \mathrm{d})$ and Delaware $(0.04 \mathrm{Mgal} / \mathrm{d})$ were reported to be from groundwater sources, whereas withdrawals in the other states were reported to be mostly from surface-water sources (Pennsylvania, $6.79 \mathrm{Mgal} / \mathrm{d}, 60$ percent surface water and 40 percent groundwater; New York, $3.33 \mathrm{Mgal} / \mathrm{d}, 87$ percent surface water and 13 percent groundwater.)

\section{Aquaculture Withdrawals}

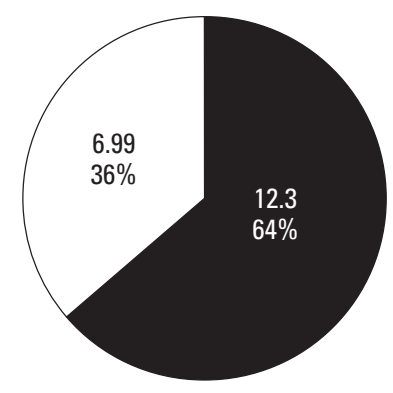

Groundwater

Surface water

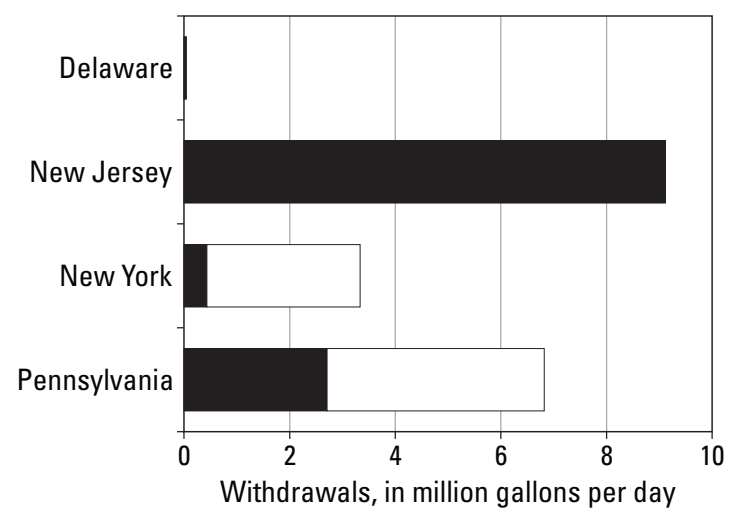

Figure 31. Distribution of aquaculture water withdrawals by source and state in the Delaware River Basin, 2010. (\%, percent) 


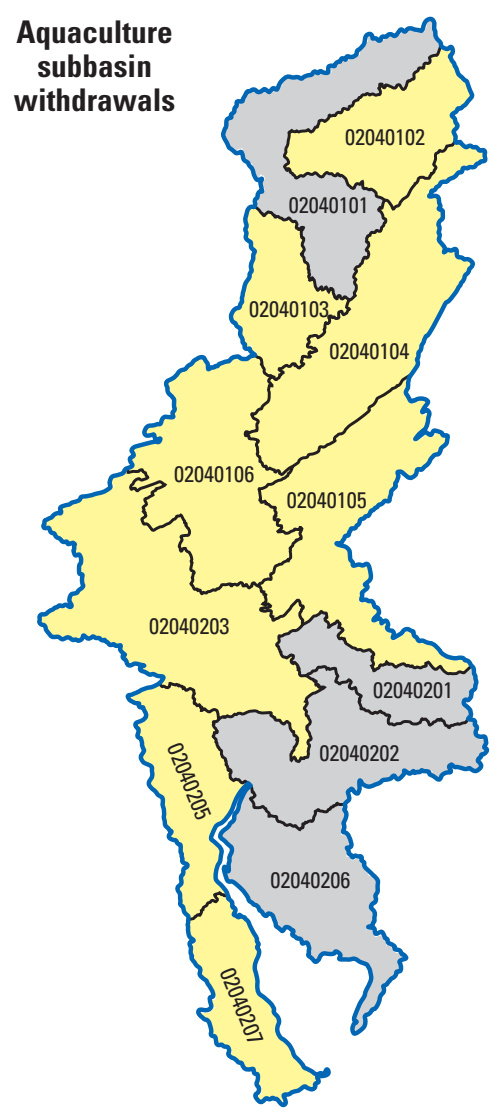

EXPLANATION

Withdrawals, in million gallons per day
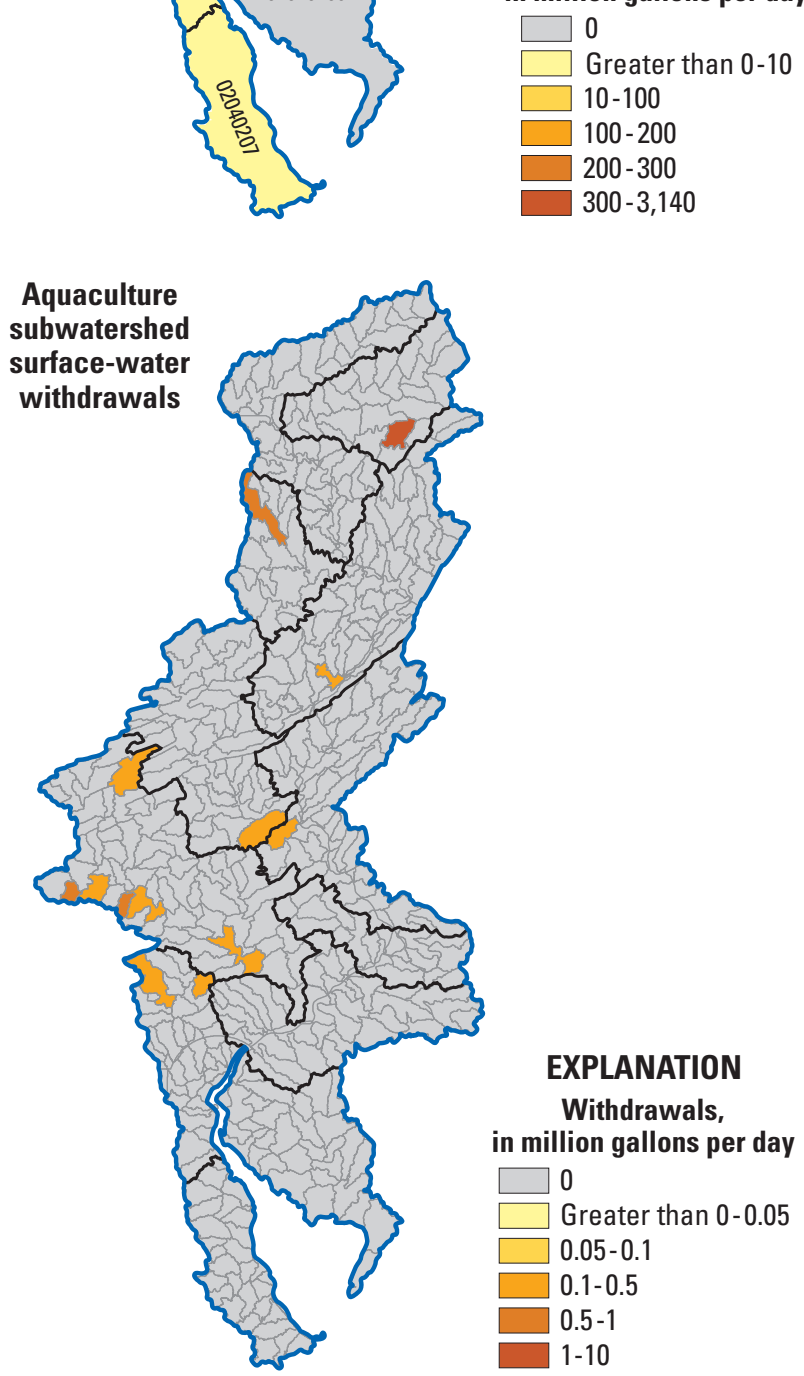
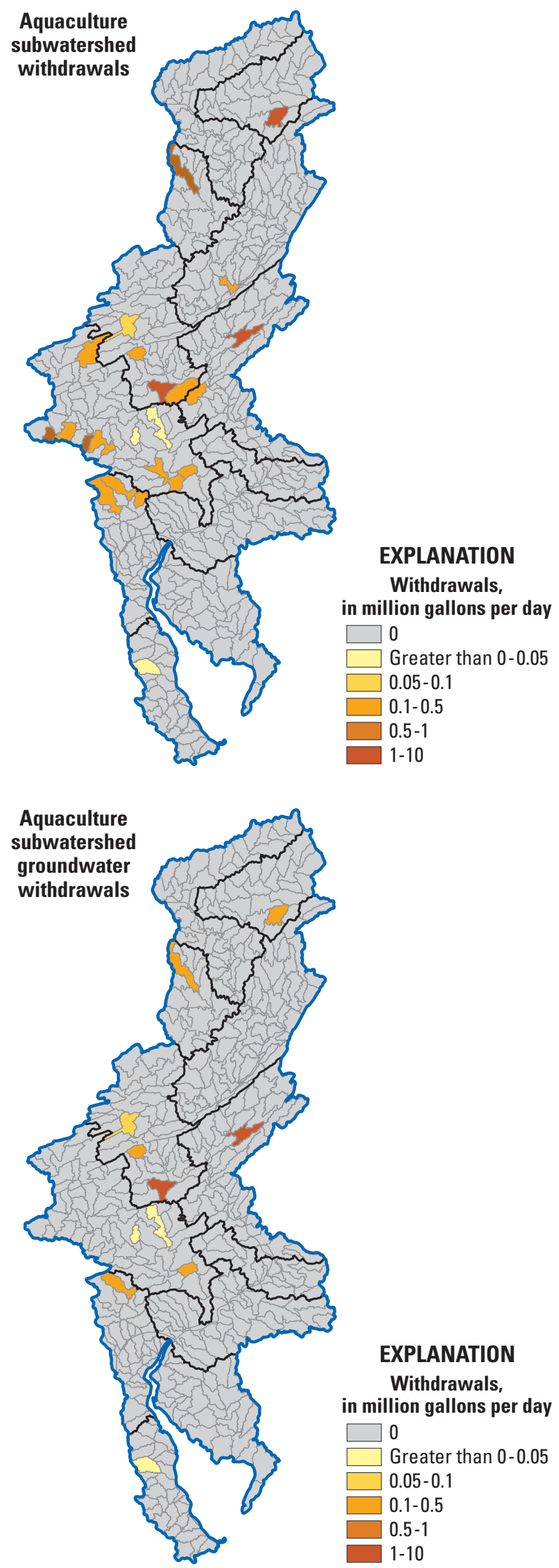

Figure 32. Aquaculture water withdrawals by source, subbasin, and subwatershed in the Delaware River Basin, 2010. 


\section{Return Flow}

Total return flows in the Delaware River Basin were 2,960 Mgal/d (table 23), or 3,320 thousand acre-ft/yr in 2010. Thirty-eight percent $(1,110 \mathrm{Mgal} / \mathrm{d})$ of the total returns were in subbasin 02040202, which has a large number of municipalities that discharge to the tidal river (fig. 33). Eighty-seven percent $(2,590 \mathrm{Mgal} / \mathrm{d})$ of the returns were in the lower part of the DRB, mainly on the larger rivers. Only 13 percent ( $372 \mathrm{Mgal} / \mathrm{d}$ ) of the returns occurred in the upper part of the DRB. Two subwatersheds (020402020601, $676 \mathrm{Mgal} / \mathrm{d}$, and
020402010404, $597 \mathrm{Mgal} / \mathrm{d}$ ) accounted for 43 percent of the total return flows.

Data were reported for a total of 554 return-flow sites (fig. 34) in 2010. Although municipal wastewater-treatment plants accounted for 539 (97 percent) of the sites, they accounted for about 70 percent of the total return flows in the DRB. There was limited information on return flows from thermoelectric power. Of the 554 return-flow sites, only 3 were thermoelectric powerplants; these 3 plants accounted for 30 percent $(872 \mathrm{Mgal} / \mathrm{d})$ of the total DRB returns.

Table 23. Total return flows, 2010.

[Values may not sum to totals because of independent rounding.]

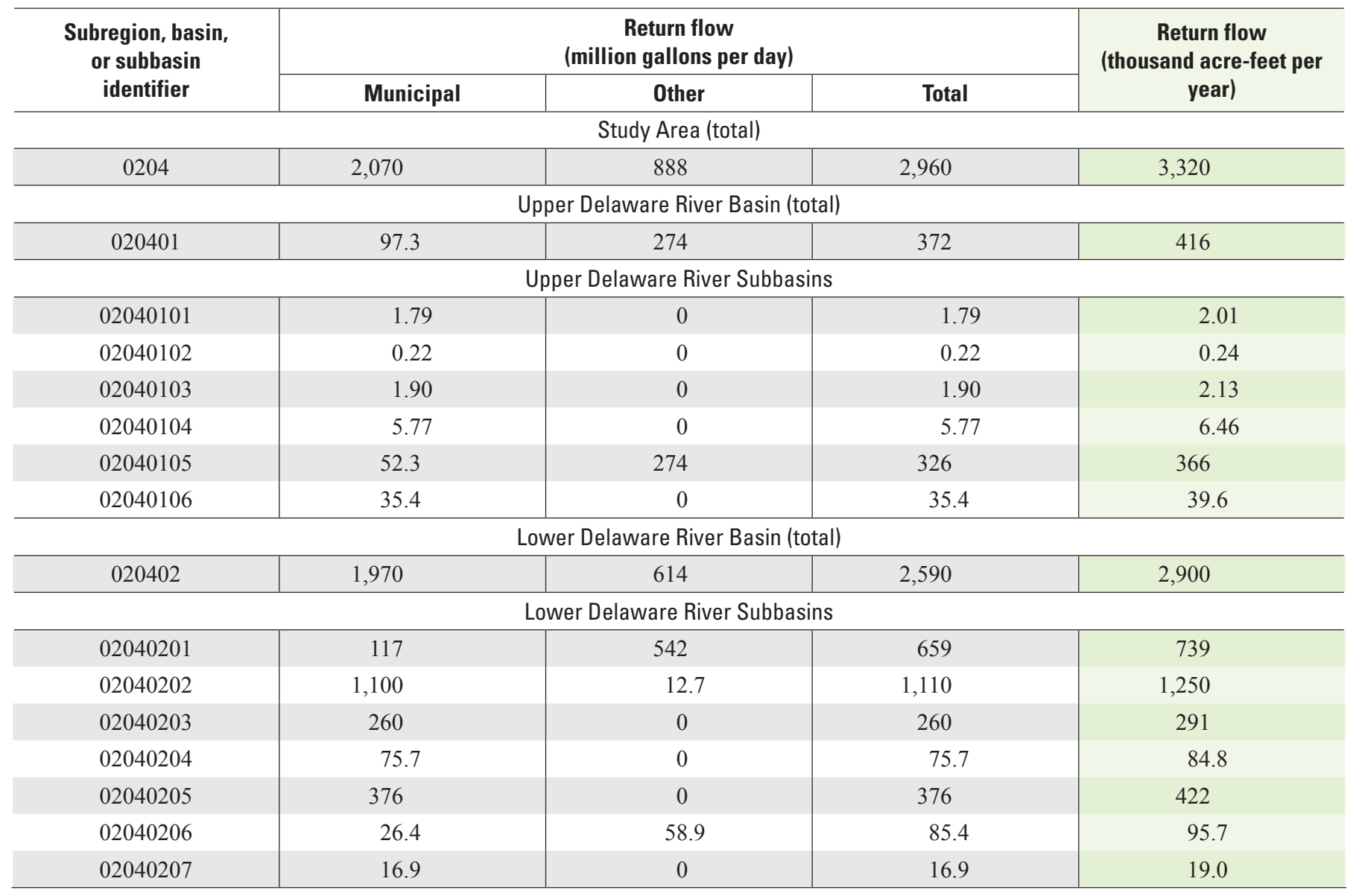



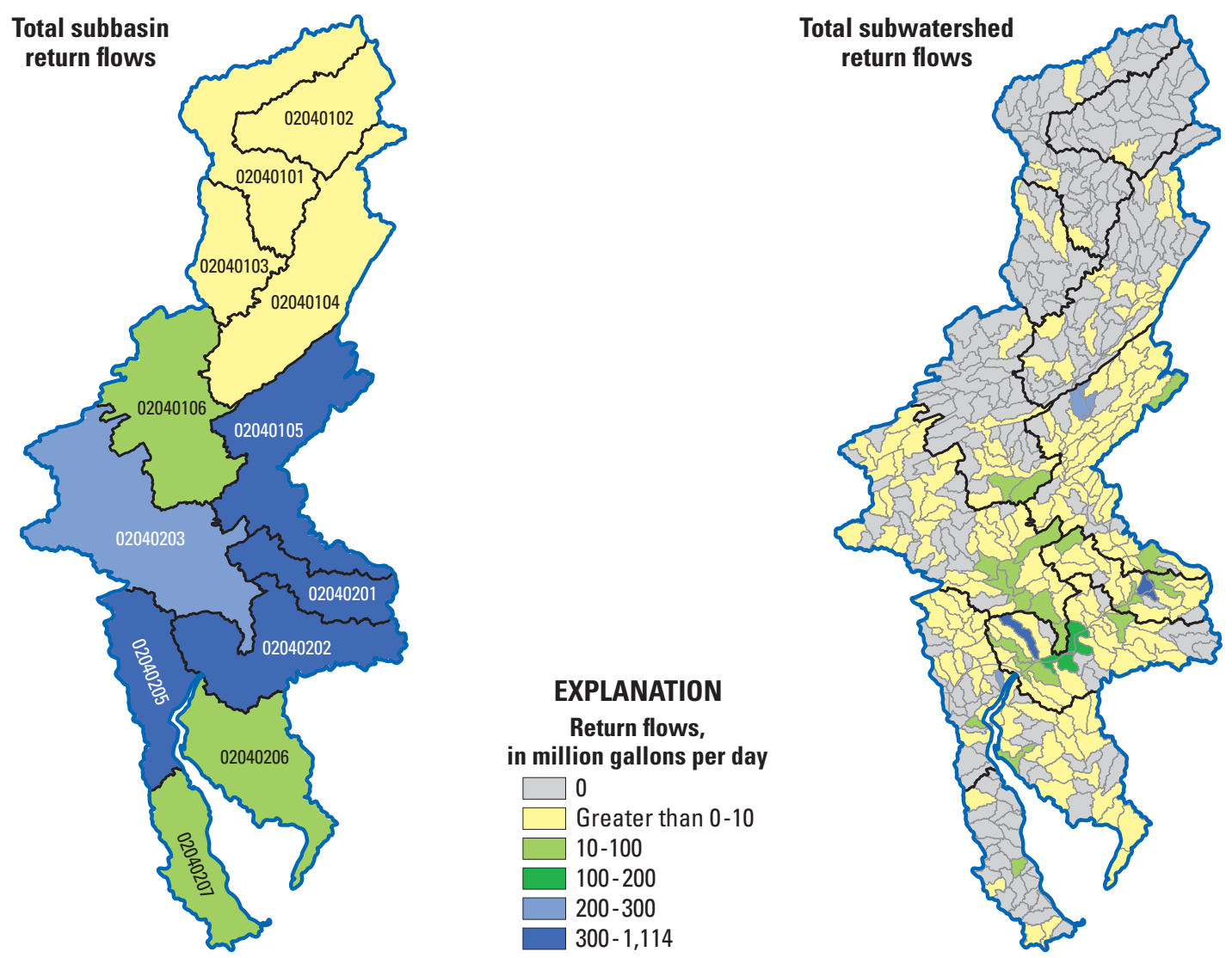

Figure 33. Return flows by subbasin and subwatershed in the Delaware River Basin, 2010.

\section{Number of Return-Flow Sites}

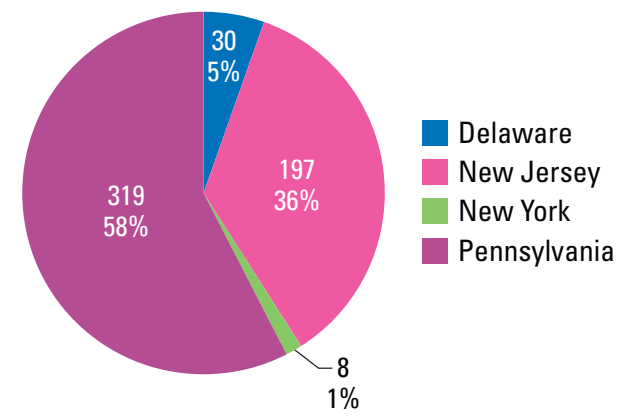

Figure 34. Number of return-flow sites by state in the Delaware River Basin, 2010. (\%, percent) 


\section{Summary}

To address water availability and water use concerns, the Delaware River Basin (DRB) was selected as a Focus Study Area in 2011 by the U.S. Geological Survey (USGS) as part of the USGS National Water Census. Instream and offstream water use was calculated for 2010 for the DRB based on information received from Delaware, New Jersey, New York, and Pennsylvania.

Water withdrawal, interbasin transfers, return flow, and hydroelectric power generation release data were compiled for 11 categories by hydrologic subregion, basin, subbasin, and subwatershed. Site-specific data from all the states were the basis for calculations of water withdrawals for thermoelectric power, public supply, self-supplied industrial, mining, and aquaculture; of instream use for hydroelectric power; and of return flows. Site-specific information was used in New Jersey for all categories except self-supplied domestic. Areal estimates based on county data were made for Delaware, New York, and Pennsylvania for the categories of self-supplied domestic and livestock; irrigation water withdrawals in these states were estimated using site-specific information for golf course irrigation and areal estimates for crop irrigation. Data on commercial water withdrawals were only available for New Jersey and Pennsylvania.

Total water withdrawals in the DRB were calculated to be about 7,130 million gallons per day (Mgal/d) in 2010 . Estimates of withdrawals by source indicate that freshwater withdrawals were about 4,130 Mgal/d (58 percent of the total) and the remaining 3,000 Mgal/d (42 percent) were from saline water. Total surface-water withdrawals were calculated to be $6,590 \mathrm{Mgal} / \mathrm{d}$, or 92 percent of the total; about 54 percent $(3,590 \mathrm{Mgal} / \mathrm{d})$ of surface water withdrawn was freshwater. Total groundwater withdrawals were calculated to be $545 \mathrm{Mgal} / \mathrm{d}$ (8 percent of the total), all of which was freshwater. During 2010, calculated withdrawals by category, in decreasing order, were: thermoelectric power, 4,910 Mgal/d; public supply, 1,490 Mgal/d; self-supplied industrial, $350 \mathrm{Mgal} / \mathrm{d}$; irrigation, $175 \mathrm{Mgal} / \mathrm{d}$; self-supplied domestic, $117 \mathrm{Mgal} / \mathrm{d}$; mining, $41.3 \mathrm{Mgal} / \mathrm{d}$; aquaculture, $19.3 \mathrm{Mgal} / \mathrm{d}$; livestock, $6.72 \mathrm{Mgal} / \mathrm{d}$, and commercial, 5.89 Mgal/d.

Thermoelectric power generation represented 69 percent $(4,910 \mathrm{Mgal} / \mathrm{d})$ of total withdrawals in the DRB and 47 percent $(1,920 \mathrm{Mgal} / \mathrm{d})$ of all freshwater withdrawals. Calculated saline water withdrawals for thermoelectric power generation were 2,990 Mgal/d, which represents almost all of the total saline water withdrawal in the basin. Almost all of the freshwater withdrawn for thermoelectric power generation in the DRB was from surface-water sources; less than 1 percent (3.00 Mgal/d) was from groundwater sources.

Public supply and self-supplied domestic withdrawals were about 23 percent of total water withdrawals and about 73 percent of total water withdrawals for all categories excluding thermoelectric power. Calculated withdrawals by source for public supply were 83 percent $(1,240 \mathrm{Mgal} / \mathrm{d})$ surface water and 17 percent $(253 \mathrm{Mgal} / \mathrm{d})$ groundwater. Withdrawals for self-supplied residential were estimated to be $117 \mathrm{Mgal} / \mathrm{d}$, all of which was considered to be from groundwater sources. Of the 1,490 Mgal/d withdrawn for public supply, $651 \mathrm{Mgal} / \mathrm{d}$ (44 percent) was transferred out of the DRB. Some water withdrawn in the Susquehanna River Basin (32.4 Mgal/d) is transferred into the DRB for public supply uses.

Self-supplied industrial (361 Mgal/d), mining (41.3 Mgal/d), and commercial (5.89 Mgal/d) withdrawals were about 6 percent of total water withdrawals and about 18 percent of total water withdrawals for all categories excluding thermoelectric power. Calculated withdrawals by source for self-supplied industrial were 89 percent (323 Mgal/d) surface water and 11 percent $(37.9 \mathrm{Mgal} / \mathrm{d})$ groundwater; for mining, 79 percent $(32.6 \mathrm{Mgal} / \mathrm{d})$ surface water and 21 percent $(8.78 \mathrm{Mgal} / \mathrm{d})$ groundwater; and for commercial, 26 percent $(1.54 \mathrm{Mgal} / \mathrm{d})$ surface water and 74 percent $(4.35 \mathrm{Mgal} / \mathrm{d})$ groundwater.

Irrigation (175 Mgal/d), aquaculture (19.3 Mgal/d), and livestock (6.72 Mgal/d) withdrawals were about 3 percent of total water withdrawals and about 9 percent of total water withdrawals for all categories excluding thermoelectric power. Calculated withdrawals by source for irrigation were 41 percent $(72.3 \mathrm{Mgal} / \mathrm{d})$ surface water and 59 percent (103 Mgal/d) groundwater; for aquaculture, 36 percent $(6.99 \mathrm{Mgal} / \mathrm{d})$ surface water and 64 percent $(12.3 \mathrm{Mgal} / \mathrm{d})$ groundwater; and for livestock, 10 percent $(0.64 \mathrm{Mgal} / \mathrm{d})$ surface water and 90 percent $(6.08 \mathrm{Mgal} / \mathrm{d})$ groundwater.

Water withdrawals were calculated at the hydrologic subregion (the entire DRB), basin (the Upper and Lower DRB), subbasin (8-digit hydrologic unit), and subwatershed (12-digit hydrologic unit) levels for all categories. The Lower basin (020402) accounted for about 71 percent (2,940 Mgal/d) of the calculated total freshwater withdrawals. The largest freshwater withdrawals in the Lower basin were for thermoelectric power (1,660 Mgal/d) and for public supply (682 $\mathrm{Mgal} / \mathrm{d})$ and accounted for 85 percent $(2,150 \mathrm{Mgal} / \mathrm{d})$ of the total surface-water withdrawals in the Lower basin. Subbasin 02040206 accounted for about 44 percent $(3,130 \mathrm{Mgal} / \mathrm{d})$ of the calculated total withdrawals, however 95 percent $(2,980$ $\mathrm{Mgal} / \mathrm{d}$ ) of this was saline water withdrawn from the estuary in New Jersey in subwatershed 020402060602 for thermoelectric power generation.

The subbasin with the largest water withdrawals for thermoelectric power generation (02040206) accounted for 61 percent $(2,990 \mathrm{Mgal} / \mathrm{d})$ of the thermoelectric power generation water withdrawn in the DRB and was all saline water; most of this water was used by a single facility. The largest freshwater withdrawals were in subbasins 02040202 (706 Mgal/d) and 02040201 (478 Mgal/d) and accounted for 62 percent $(1,180 \mathrm{Mgal} / \mathrm{d})$ of the total freshwater withdrawals for thermoelectric power generation in the DRB. The subwatershed with the largest saline water withdrawals $(2,980 \mathrm{Mgal} / \mathrm{d})$ was 020402060602 , where the PSEG Salem Generating Station Powerplant is located. The subwatershed with the largest freshwater withdrawals (690 Mgal/d) was 020402020601, where the Exelon Eddystone Powerplant is 
located. The amount of instream use for hydroelectric power generation purposes in 2010 was reported to be $273 \mathrm{Mgal} / \mathrm{d}$ for the Wallenpaupack plant and $127 \mathrm{Mgal} / \mathrm{d}$ for the Mongaup River system.

The Upper basin (020401) accounted for 53 percent $(846 \mathrm{Mgal} / \mathrm{d})$ of the total Drinking Water sector withdrawals, whereas the Lower basin (020402) accounted for 47 percent (763 Mgal/d). Out-of-basin drinking-water exports accounted for $651 \mathrm{Mgal} / \mathrm{d}$ (77 percent) of Drinking Water sector withdrawals in the Upper basin. Drinking Water sector withdrawals were dominated by public supply water withdrawals in the Upper basin for New York City, and in the Lower basin for the greater Philadelphia area.

An estimated 14.7 million people relied on drinking water withdrawn in the DRB for their household use; over 8 million people outside of the Basin (in New York City and New Jersey) and 6.7 million people within the DRB. The publicly supplied population of the DRB represents about 81 percent of the total 2010 DRB population of approximately 8.2 million people. The subbasins with the largest water withdrawals for public supply were those in which withdrawals for New York City, Philadelphia, and Trenton, New Jersey occurred.

Three subbasins (02040103, 02040206, and 02040207) had public supply withdrawals almost exclusively (greater than 99 percent) from groundwater sources. Two subbasins (02040101 and 02040102) had public supply withdrawals almost exclusively (greater than 99 percent) from surfacewater sources due to the withdrawal and subsequent transfer of water to New York City; however, groundwater sources accounted for most of the publicly supplied water use for residents within these two subbasins of the DRB.

The six subwatersheds with the largest surface-water withdrawals for public supply water use were the three subwatersheds that include reservoirs that are part of the New York City supply system (020401020405, Pepacton Reservoir, $334 \mathrm{Mgal} / \mathrm{d}$; 020401010207, Cannonsville Reservoir, $145 \mathrm{Mgal} / \mathrm{d}$; and 020401040303 , Neversink Reservoir, 94.7 Mgal/d) and the three subwatersheds where water is withdrawn to supply the City of Philadelphia (020402031008, $121 \mathrm{Mgal} / \mathrm{d}$ ), the City of Camden, New Jersey (020401050803, 77.3 Mgal/d), and the City of Trenton, New Jersey (020402020305, $178 \mathrm{Mgal} / \mathrm{d}$ ) along with other uses along the Delaware and Raritan Canal. The four subwatersheds with the largest groundwater withdrawals were 020401060703 (12.5 Mgal/d, in the vicinity of Allentown, Pennsylvania) and three subwatersheds in the vicinity of Camden, New Jersey (020402020401, $15.2 \mathrm{Mgal} / \mathrm{d}$; 020402020404, $11.8 \mathrm{Mgal} / \mathrm{d}$; and 020402020403, $10.2 \mathrm{Mgal} / \mathrm{d})$.

An estimated 1.56 million people within the DRB supplied their own water for domestic use in 2010. This number represents about 19 percent of the total 2010 DRB population of approximately 8.2 million people. Over half (62.2 Mgal/d) of the self-supplied domestic withdrawals were from three subbasins (02040203, 02040105, and 02040202), which contained 64 percent of the total population of the DRB. Selfsupplied domestic withdrawals were greatest outside of metropolitan areas such as Philadelphia, Pennsylvania; Wilmington, Delaware; and Trenton, New Jersey.

The Lower basin accounted for 91 percent (371 Mgal/d) of the total Industrial sector withdrawals, whereas the Upper basin accounted for 9 percent $(37.3 \mathrm{Mgal} / \mathrm{d})$. The Lower basin Industrial sector water withdrawals were 91 percent from surface-water sources (339 Mgal/d) and 9 percent (31.6 Mgal/d) from groundwater sources. The Upper basin Industrial sector withdrawals were almost equally distributed between sources, with 52 percent from groundwater sources $(19.5 \mathrm{Mgal} / \mathrm{d})$ and 48 percent from surface-water sources $(17.9 \mathrm{Mgal} / \mathrm{d})$.

The four subbasins with the largest water withdrawals for industrial use (02040202, 02040205, 02040203, and $02040201)$ accounted for 83 percent $(298 \mathrm{Mgal} / \mathrm{d})$ of the industrial water withdrawn in the DRB. These subbasins include the urban areas surrounding Camden and Trenton, New Jersey; Philadelphia, Pennsylvania; and Wilmington, Delaware. The four subwatersheds with the largest surfacewater withdrawals, also located near these urban areas, were 020402020607 (73.9 Mgal/d), 020402050704 (71.4 Mgal/d), 020402010404 (38.4 Mgal/d), and 020402031008

(27.4 Mgal/d). One subbasin, the Lower Delaware (02040202), had industrial surface-water withdrawals that accounted for 34 percent $(110 \mathrm{Mgal} / \mathrm{d})$ of the total for the DRB. Another subbasin, the Lehigh River (02040106), accounted for 28 percent $(10.5 \mathrm{Mgal} / \mathrm{d})$ of industrial groundwater withdrawals. The subwatershed with the largest groundwater withdrawals $(5.62 \mathrm{Mgal} / \mathrm{d})$ was 020401060810 , in the vicinity of Allentown and Bethlehem, Pennsylvania. The only subwatershed where saline surface-water withdrawals for industrial use were reported was 020402060103

(10.6 Mgal/d), near Wilmington, Delaware.

Subbasin 02040206 had the largest water withdrawals for commercial use and accounted for 42 percent $(2.45 \mathrm{Mgal} / \mathrm{d})$ of the commercial water withdrawn in the DRB; all of these withdrawals were from groundwater sources, and the largest of them came from a single facility in subwatershed 020402060103. Three subbasins (02040202, 02040104, and 02040106) accounted for another 44 percent $(2.62 \mathrm{Mgal} / \mathrm{d})$ of commercial groundwater withdrawals. The largest amount of surface water $(0.59 \mathrm{Mgal} / \mathrm{d})$ was withdrawn in subwatershed 020401040803, in the Pocono Mountains region of Pennsylvania.

The subbasin with the largest water withdrawals for mining use (02040206) accounted for 79 percent (32.6 Mgal/d) of the mining water withdrawn in the DRB. The same subbasin had mining surface-water withdrawals that accounted for 78 percent (32.3 Mgal/d) of the total mining withdrawals for the DRB. The majority of mining withdrawals (25.2 Mgal/d) were in subwatershed 020402060605 . Three subbasins (02040203, 02040105, and 02040201) accounted for another 19 percent $(7.92 \mathrm{Mgal} / \mathrm{d})$ of mining withdrawals and were almost exclusively from groundwater sources. Two subwatersheds combined to account for 57 percent of 
the total groundwater withdrawals for mining in the DRB $020402030204(2.67 \mathrm{Mgal} / \mathrm{d})$ and 020401050908

(2.36 Mgal/d). No withdrawals were reported for mining purposes in subbasins 02040101, 02040103, 02040205, and 02040207.

The Lower basin (020402) accounted for 79 percent $(158 \mathrm{Mgal} / \mathrm{d})$ of the total Agricultural sector withdrawals, whereas the Upper basin (020401) accounted for 21 percent (42.6 Mgal/d). The Lower basin water withdrawals were about two-thirds from groundwater sources (105 Mgal/d of groundwater, $53.4 \mathrm{Mgal} / \mathrm{d}$ of surface water) and were used for primarily for irrigation. The Upper basin withdrawals were about two-thirds from surface-water sources $(26.5 \mathrm{Mgal} / \mathrm{d}$ of surface water and $16.2 \mathrm{Mgal} / \mathrm{d}$ of groundwater) and were used primarily for irrigation and aquaculture.

The subbasins with the largest water withdrawals for irrigation use (02040207, 02040206, and 02040202) were located primarily in the Coastal Plain in the southeastern part of the DRB. These subbasins accounted for almost three-quarters (129 Mgal/d) of the irrigation water withdrawals. Two subbasins in the Coastal Plain (02040206 and 02040207) had irrigation groundwater withdrawals that accounted for 84 percent ( $86.3 \mathrm{Mgal} / \mathrm{d}$ ) of the total irrigation groundwater withdrawals for the DRB; one subbasin (02040202) accounted for 30 percent $(21.8 \mathrm{Mgal} / \mathrm{d})$ of irrigation surface-water withdrawals. The subwatersheds with the largest groundwater and surfacewater withdrawals were also located in the Coastal Plain of New Jersey and Delaware.

The subbasins with the largest water withdrawals for livestock use (02040203, 02040205, and 02040206) accounted for 70 percent $(4.68 \mathrm{Mgal} / \mathrm{d})$ of the livestock water withdrawn. These three subbasins accounted for 60 percent $(4.17 \mathrm{Mgal} / \mathrm{d}$ ) of the total livestock groundwater withdrawals for the DRB; one subbasin (02040203) accounted for 64 percent ( $0.41 \mathrm{Mgal} / \mathrm{d})$ of livestock surface-water withdrawals. The two subwatersheds with the largest withdrawals were $020402030402(0.23 \mathrm{Mgal} / \mathrm{d})$ in Pennsylvania and $020402060404(0.22 \mathrm{Mgal} / \mathrm{d})$ in New Jersey.

Subbasin 02040105 had the largest water withdrawals for aquaculture use and accounted for almost half $(9.36 \mathrm{Mgal} / \mathrm{d})$ of the aquaculture water withdrawn in the DRB. One subwatershed (020401050204) in New Jersey accounted for almost all $(9.11 \mathrm{Mgal} / \mathrm{d})$ of this amount, in addition to 74 percent of the total groundwater withdrawals. Two subbasins (02040102 and 02040203$)$ accounted for 73 percent $(5.10 \mathrm{Mgal} / \mathrm{d})$ of aquaculture surface-water withdrawals, more than half (2.90 Mgal/d) of which was withdrawn in subwatershed 020401020103 in New York.

Total return flows in the DRB were $2,960 \mathrm{Mgal} / \mathrm{d}$, or 3,320 thousand acre-feet per year, in 2010. Thirty-eight percent $(1,110 \mathrm{Mgal} / \mathrm{d})$ of the total return flows were in subbasin 02040202. Eighty-seven percent (2,590 Mgal/d) of the returns were in the lower part of the DRB; only 13 percent (372 Mgal/d) of the returns occurred in the upper part of the DRB. Two subwatersheds (020402020601, $676 \mathrm{Mgal} / \mathrm{d}$, and 020402010404, $597 \mathrm{Mgal} / \mathrm{d}$ ) accounted for 43 percent of the total return flows.
Data were reported for a total of 554 return-flow sites. Although municipal wastewater-treatment plants accounted for 539 (97 percent) of the sites, they accounted for about 70 percent of the total return flows in the DRB. There was limited information available on return flows from thermoelectric power. Of the 554 return-flow sites, only 3 were thermoelectric powerplants; these 3 plants accounted for 30 percent (872 Mgal/d) of the total DRB returns.

\section{Selected References}

Alley, W.M., Evenson, E.J., Barber, N.L., Bruce, B.W., Dennehy, K.F., Freeman, M.C., Freeman, W.O., Fischer, J.M., Hughes, W.B., Kennen, J.G., Kiang, J.E., Maloney, K.O., Musgrove, Mary Lynn, Ralston, Barbara, Tessler, Steven, and Verdin, J.P., 2013, Progress toward establishing a National assessment of water availability and use: U.S. Geological Survey Circular 1384, 34 p., accessed June 1, 2014, at http://pubs.usgs.gov/circ/1384/.

Delaware Department of Natural Resources and Environmental Control, Division of Water, Water Supply Section, Water Allocation Branch, water withdrawal threshold information accessed June 9, 2014, at http://www.dnrec. delaware.gov/wr/SERVICES/OTHERSERVICES/Pages/ WaterSupplyWaterAllocationBranch.aspx.

Delaware River Basin Commission, Ground water protected area regulations, Southeastern Pennsylvania, accessed June 9, 2014, at http://www.state.nj.us/drbc/library/documents/gwpa_regs.pdf.

Diehl, T.H., Harris, M.A., Murphy, J.C., Hutson, S.S., and Ladd, D.E., 2013, Methods for estimating water consumption for thermoelectric power plants in the United States: U.S. Geological Survey Scientific Investigations Report 2013-5188, 78 p., accessed May 16, 2016, at http://dx.doi. org/10.3133/sir20135188.

Eagle Creek Renewable Energy, 2014, accessed June 5, 2014, at http://www.eaglecreekre.com/facilities/northeast-region/ mongaup-river-ny.

Fenneman, N.M., and Johnson, D.W., 1946, Physiographic divisions of the conterminous U.S., map data accessed September 8, 2015, at http://water.usgs.gov/GIS/metadata/ usgswrd/XML/physio.xml.

Fischer, J.M., Riva-Murray, K., Hickman, R.E., Chichester, D.C., Brightbill, R.A., Romanok, K.M., and Bilger, M.D, 2004, Water quality in the Delaware River Basin, Pennsylvania, New Jersey, New York, and Delaware, 1998-2001: U.S. Geological Survey Circular 1227, 39 p., accessed June 5, 2014, at http://pubs.usgs.gov/ circ/2004/1227/. 
Hutson, S.S., Barber, N.L., Kenny, J.F., Linsey, K.S., Lumia, D.S., and Maupin, M.A., 2004, Estimated use of water in the United States in 2000: U.S. Geological Survey Circular 1268, 46 p., accessed June 1, 2014, at http://pubs.usgs.gov/ circ/2004/circ1268/.

Jenner, C.B., and Lins, H.F., 1991, Climatic atlas of the Delaware River Basin: U.S. Geological Survey Professional Paper 1392, 127 p., accessed June 1, 2014, at http://pubs. er.usgs.gov/publication/pp1392.

Kenny, J.F., Barber, N.L., Hutson, S.S., Linsey, K.S., Lovelace, J.K., and Maupin, M.A., 2009, Estimated use of water in the United States in 2005: U.S. Geological Survey Circular 1344, 52 p., accessed June 1, 2014, at http://pubs. usgs.gov/circ/1344/.

Lovelace, J.K., 2009, Method for estimating water withdrawals for livestock in the United States, 2005: U.S. Geological Survey Scientific Investigations Report 20095041, 7 p., accessed June 1, 2014, at http://pubs.usgs.gov/ $\operatorname{sir} / 2009 / 5041 /$.

MacKichan, K.A., 1951, Estimated use of water in the United States, 1950: U.S. Geological Survey Circular 115, 13 p., accessed June 1, 2014, at http://pubs.usgs.gov/circ/1951/ $\operatorname{circ} 115 /$.

MacKichan, K.A., 1957, Estimated use of water in the United States, 1955: U.S. Geological Survey Circular 398, 18 p., accessed June 1, 2014, at http://pubs.er.usgs.gov/ publication/cir398.

MacKichan, K.A., and Kammerer, J.C., 1961, Estimated use of water in the United States, 1960: U.S. Geological Survey Circular 456, 44 p., accessed June 1, 2014, at http://pubs. er.usgs.gov/publication/cir456.

Masterson, J.P., Pope, J.P., Monti, Jack, Jr., Nardi, M.R., Finkelstein, J.S., and McCoy, K.J., 2013, Hydrogeology and hydrologic conditions of the Northern Atlantic Coastal Plain aquifer system from Long Island, New York, to North Carolina: U.S. Geological Survey Scientific Investigations Report 2013-5133, 76 p., accessed June 5, 2014 at http:// dx.doi.org/10.3133/sir20135133.

Maupin, M.A., Kenny, J.F., Hutson, S.S., Lovelace, J., Barber, N.L., and Linsey, K.S., 2014, Estimated use of water in the United States in 2010: U.S. Geological Survey Circular 1405, 56 p., accessed November 30, 2014, at http://pubs. usgs.gov/circ/1405/.

Murray, C.R., 1968, Estimated use of water in the United States, 1965: U.S. Geological Survey Circular 556, 53 p., accessed June 1, 2014, at http://pubs.er.usgs.gov/ publication/cir556.
Murray, C.R., and Reeves, E.B., 1972, Estimated use of water in the United States in 1970: U.S. Geological Survey Circular 676, 37 p., accessed June 1, 2014, at http://pubs. er.usgs.gov/publication/cir676.

Murray, C.R., and Reeves, E.B., 1977, Estimated use of water in the United States in 1975: U.S. Geological Survey Circular 765, 37 p., accessed June 1, 2014, at http://pubs. er.usgs.gov/publication/cir765.

New Jersey Department of Environmental Protection (DEP), Bureau of Water Allocation \& Well Permitting, water withdrawal threshold information, accessed March 11, 2014, at http://www.nj.gov/dep/watersupply/.

New Jersey Department of Environmental Protection, 2014, DEP Highlands Water Protection \& Planning Act guidance, accessed June 9, 2014, at http://www.state.nj.us/dep/ highlands/.

New York State Department of Environmental Conservation, Division of Water, 2014, water withdrawal threshold information, accessed June 9, 2014, at http://www.dec.ny.gov/ about/661.html.

Parker, G.G., Hely, A.G., Keighton, W.B., and Olmsted, F.H., 1964, Water resources of the Delaware River basin: U.S. Geological Survey Professional Paper 381, 200 p., accessed September 8, 2015, at http://pubs.er.usgs.gov/publication/ pp381.

Partnership for the Delaware Estuary (PDE), 2012, Technical report for the Delaware Estuary and Basin: PDE Report No. 12-01, 255 p., accessed September 8, 2015, at http://delawareestuary.org/technical-report-delaware-estuary-basin.

Pennsylvania Department of Environmental Protection, 2014, accessed June 9, 2014, at http://www.depweb.state.pa.us/ portal/server.pt/community/water/6008.

Pennsylvania Power and Light, 2014, Wallenpaupack Hydroelectric Power Plant information, accessed June 5, 2014, at http://www.pplweb.com/ppl-generation/ppl-wallenpaupack.aspx.

Ries, K.G., III, Horn, M.A., Nardi, M.R., and Tessler, S., 2010, Incorporation of water use summaries into the StreamStats web application for Maryland: U.S. Geological Survey Scientific Investigations Report 2010-5111, 18 p., accessed June 1, 2014, at http://pubs.usgs.gov/sir/2010/5111/.

Sloto, R.A. and Buxton, D.E., 2006, Estimated ground-water availability in the Delaware River Basin, 1997-2000: U.S. Geological Survey Scientific Investigations Report 20065125, 67 p., accessed June 1, 2014, at http://pubs.usgs.gov/ $\operatorname{sir} / 2006 / 5125 /$. 
Solley, W.B., Chase, E.B., and Mann, W.B., IV, 1983, Estimated use of water in the United States in 1980: U.S. Geological Survey Circular 1001, 56 p., accessed June 1, 2014, at http://pubs.er.usgs.gov/publication/cir1001.

Solley, W.B., Merk, C.F., and Pierce, R.R., 1988, Estimated use of water in the United States in 1985: U.S. Geological Survey Circular 1004, 82 p., accessed June 1, 2014, at http://pubs.er.usgs.gov/publication/cir1004.

Solley, W.B., Pierce, R.R., and Perlman, H.A., 1993, Estimated use of water in the United States in 1990: U.S. Geological Survey Circular 1081, 76 p., accessed June 1, 2014, at http://pubs.er.usgs.gov/publication/cir1081.

Solley, W.B., Pierce, R.R., and Perlman, H.A., 1998, Estimated use of water in the United States in 1995: U.S. Geological Survey Circular 1200, 71 p., accessed June 1, 2014, at http://pubs.er.usgs.gov/publication/cir1200.

U.S. Census Bureau, 1991, 1990 Census of Population and Housing, (table 13), accessed May 27, 2014, at http://www. census.gov/prod/www/decennial.html.

U.S. Census Bureau, 2014, Geography, accessed June 5, 2014, at http://www.census.gov/geo/index.html.

U.S. Department of Agriculture, National Agricultural Statistics Service, 2010, 2010 Cropland Data Layer, accessed May 25, 2016, at https://www.nass.usda.gov/ Research_and_Science/Cropland/Release/index.php.

U.S. Department of Agriculture, Natural Resources Conservation Service, 2014, Watershed Boundary Dataset, accessed May 25, 2016, at http://www.nrcs.usda.gov/wps/ portal/nrcs/main/national/water/watersheds/dataset/.

U.S. Environmental Protection Agency, 2000, National water quality inventory - 1998 report: U.S. Environmental Protection, Agency Report EPA-841-F-00-006, 45 p.

U.S. Environmental Protection Agency, 2014, Water: Underground Injection Control, Aquifer Recharge (AR) and Aquifer Storage \& Recovery (ASR), accessed June 9, 2014, at http://water.epa.gov/type/groundwater/uic/aquiferrecharge.cfm.

U.S. Geological Survey, 2007, Facing tomorrow's challenges-U.S. Geological Survey science in the decade 2007-2017: U.S. Geological Survey Circular 1309, 69 p., accessed June 1, 2014, at http://pubs.usgs.gov/ circ/2007/1309/.

U.S. Geological Survey, 2013, National Water Information System, USGS current water data for New Jersey, accessed May 8, 2013, at http://waterdata.usgs.gov/nj/nwis/rt.
U.S. Geological Survey, 2014a, Agreement of the parties to the 1954 U.S. Supreme Court Decree effective June 1, 2014, accessed June 5, 2014, at http://water.usgs.gov/osw/ odrm/documents/FFMP_2014_Agreement.pdf.

U.S. Geological Survey, 2014b, National Water Census, accessed May 28, 2014, at http://water.usgs.gov/ watercensus.

U.S Geological Survey, 2014c, National Water Information System, USGS water data for the Nation, accessed November 1, 2014, at http://nwis.waterdata.usgs.gov/nwis.

U.S. Geological Survey, 2014d, Watershed Boundary Dataset, accessed March 13, 2014, at http://nhd.usgs.gov/wbd.html.

U.S. Geological Survey, 2014e, WaterSMART Initiative and SECURE Water Act history, accessed June 4, 2014, at http:// water.usgs.gov/watercensus/history.html\#secure.

U.S. Geological Survey and U.S. Department of Agriculture, Natural Resources Conservation Service, 2012, Federal Standards and Procedures for the National Watershed Boundary Dataset (WBD) (3d ed.): U.S. Geological Survey Techniques and Methods 11-A3, 63 p., accessed June 5, 2014, at http://pubs.usgs.gov/tm/tm11a3/.

Vigil, J.F., Pike, R.J., and Howell, D.G., 2000, A tapestry of time and terrain: U.S. Geological Survey Geologic Investigations Series 2720, 1 pl., scale 1:2,500,000, 1 pamphlet, accessed May 25, 2016, at http://pubs.usgs.gov/ imap/i2720/.

Williamson, T.N., Odom, K.R., Newson, J.K., Downs, A.C., Nelson, H.L., Jr., Cinotto, P.J., and Ayers, M.A, 2009, The Water Availability Tool for Environmental Resources (WATER): A water-budget modeling approach for managing water-supply resources in Kentucky —Phase I: Data processing, model development, and application to nonkarst areas: U.S. Geological Survey Scientific Investigations Report 2009-5248, 34 p., accessed June 1, 2014, at http:// pubs.usgs.gov/sir/2009/5248/. 



\section{Glossary}

The following terms are referenced in the text.

\section{A}

aggregated summarized values for a specific data element either by spatial area or category of use.

Agricultural sector includes the categories of irrigation, livestock, and aquaculture.

aquaculture aquaculture water use is water associated with raising organisms that live in water - such as finfish and shellfish - for food, restoration, conservation, or sport. Aquaculture production occurs under controlled feeding, sanitation, and harvesting procedures primarily in ponds, flow-through raceways, and, to a lesser extent, cages, net pens, and closed-recirculation tanks.

aquifer storage and recovery aquifer storage and recovery (ASR) is a specific type of aquifer recharge (AR) practiced with the purpose of both augmenting groundwater resources and recovering the water in the future for various uses (U.S. Environmental Protection Agency, 2014).

areal estimate water use estimate for a geographic unit such as a county, or watershed. See also subregion, basin, subbasin, and subwatershed.

artificial aquifer recharge the enhancement of natural groundwater supplies using manmade conveyances such as infiltration basins or injection wells.

\section{B}

basin hydrologically based watershed delineation assigned a 6-digit hydrologic unit code (HUC).

block group U.S. census block groups are statistical divisions of census tracts, are generally defined to contain between 600 and 3,000 people, and are used to present data and control block numbering. A block group consists of clusters of blocks within the same census tract that have the same first digit of their four-digit census block number.
C

census block U.S. census blocks are statistical areas bounded by visible features, such as streets, roads, streams, and railroad tracks, and by nonvisible boundaries, such as selected property lines and city, township, school district, and county limits and short line-of-sight extensions of streets and roads. Generally, census blocks are small in area; for example, a block in a city bounded on all sides by streets. Census blocks in suburban and rural areas may be large, irregular, and bounded by a variety of features, such as roads, streams, and transmission lines. In remote areas, census blocks may encompass hundreds of square miles. Census blocks nest within all other tabulated census geographic entities and are the basis for all tabulated data.

choropleth a symbol or marked and bounded area on a map denoting the distribution of some property.

commercial commercial water use includes water for snowmaking, motels, hotels, restaurants, office buildings, other commercial facilities, and civilian and military institutions.

consumptive use the part of water withdrawn that is evaporated, transpired, incorporated into products or crops, consumed by humans or livestock, or otherwise removed from the immediate environment.

\section{D}

Drinking Water sector includes the categories of public supply and self-supplied domestic.

\section{$\mathbf{F}$}

freshwater water that contains less than 1,000 milligrams per liter $(\mathrm{mg} / \mathrm{L})$ of dissolved solids. Generally, water with more than $500 \mathrm{mg} / \mathrm{L}$ of dissolved solids is undesirable for drinking and industrial uses. See also saline water. 
H

hydroelectric power generation the use of water in the generation of electricity at plants where the turbine generators are driven by falling water. Hydroelectric water use is classified as an instream use in this report.

See also instream water use.

\section{I}

industrial industrial water use includes water used for such purposes as fabricating, processing, washing, diluting, cooling, or transporting a product; incorporating water into a product; or for sanitation needs within the manufacturing facility. Some industries that use large amounts of water produce such commodities as food, paper, chemicals, refined petroleum, or primary metals. Water for industrial use may be delivered from a public supplier or be self-supplied. In this report, industrial use refers to self-supplied industrial withdrawals only.

Industrial sector includes the categories of industrial, commercial, and mining.

instream water use water that is used, but not withdrawn, from a surface-water source for such purposes as hydroelectric power generation, navigation, water-quality improvement, fish propagation, and recreation.

interbasin transfer artificial conveyance of water from one basin to another. In this report, interbasin transfer refers specifically to water that moves into or out of the DRB. See also water transfer.

irrigation irrigation water use includes water that is applied by an irrigation system to sustain plant growth in all agricultural and horticultural practices. Irrigation also includes water that is applied for pre-irrigation, frost protection, application of chemicals, weed control, field preparation, crop cooling, harvesting, dust suppression, leaching salts from the root zone, and water lost in conveyance. Irrigation of golf courses, parks, nurseries, turf farms, cemeteries, and other self-supplied landscape-watering uses also are included. Irrigation water use includes self-supplied withdrawals and deliveries from irrigation companies, irrigation districts, cooperatives, or governmental entities.

\section{L}

livestock livestock water use is water associated with livestock watering, feedlots, dairy operations, and other on-farm needs. Livestock includes dairy cows and heifers, beef cattle and calves, sheep and lambs, goats, hogs and pigs, horses, and poultry. Other livestock water uses include cooling of facilities for the animals and animal products such as milk, dairy sanitation and wash down of facilities, animal waste-disposal systems, and incidental water losses.

\section{M}

mining mining water use is water used for the extraction of minerals that may be in the form of solids, such as coal, iron, sand, and gravel; liquids, such as crude petroleum; and gases, such as natural gas. The category includes quarrying, milling (crushing, screening, washing, and flotation of mined materials), re-injecting extracted water for secondary oil recovery, and other operations associated with mining activities. All mining withdrawals were considered selfsupplied. Dewatering was not reported as a mining withdrawal unless the water was used beneficially, such as dampening roads for dust control.

monthly operating reports monthly data reports of average daily water withdrawals or water purchases submitted by each public supplier to a governmental agency.

municipal supply See public supply.

\section{0}

offstream water use water withdrawn or diverted from a groundwater or surface-water source for beneficial use. See also water withdrawal and water use.

\section{$\mathbf{P}$}

physiographic province geomorphic, or physiographic, regions are broad-scale subdivisions based on terrain texture, rock type, and geologic structure and history. Nevin Fenneman's (Fenneman and Johnson, 1946) three-tiered classification of the 
United States - by division, province, and section - has provided an enduring spatial organization for the great variety of physical features.

Power Generation sector includes the categories of thermoelectric power generation (offstream withdrawals) and hydroelectric power generation (instream water use).

public supply public supply refers to water withdrawn by public and private water suppliers that provide water to at least 25 people or have a minimum of 15 connections. Publicsupply statistics also include water delivered for domestic, commercial, industrial, and public use purposes, and system losses, but are excluded from the 2010 DRB water use compilation.

public supply water use water distributed within the DRB by public suppliers.

public supply withdrawals water withdrawn, treated, and distributed by public suppliers. Public suppliers provide water for a variety of uses such as residential, commercial, industrial, thermoelectric power, and public water use. In this report, public supply withdrawals refer specifically to water removed from a groundwater or surface-water source in the DRB for a beneficial purpose.

\section{R}

return flow water that reaches a groundwater or surface-water source after release from the point of use and thus becomes available for further use. See also water use.

\section{S}

saline water water that contains 1,000 $\mathrm{mg} / \mathrm{L}$ or more of dissolved solids. See also freshwater.

salt line an estimation of where the 7-day average chloride concentration equals 250 parts per million along the tidal Delaware River.

self-supplied domestic domestic water use includes indoor and outdoor uses at residences. Domestic water is either selfsupplied or provided by public suppliers. Self-supplied domestic water use is usually withdrawn from a private source, such as a well.

site-specific data data for an individual water-using entity.

subbasin hydrologically based watershed delineation assigned an 8-digit hydrologic unit code (HUC).

subregion hydrologically based watershed delineation assigned a 4-digit hydrologic unit code (HUC).

subwatershed hydrologically based watershed delineation assigned a 12-digit hydrologic unit code (HUC).

$\mathbf{T}$

thermoelectric power generation water for thermoelectric power is used in generating electricity with steam-driven turbine generators.

\section{W}

water transfer artificial conveyance of water from one area to another.

water use (1) in a restrictive sense, the term refers to water that is used for a specific purpose, such as for residential use, irrigation, thermoelectric-power cooling, or industrial processing. In this report, the quantity of water use for a specific category is the water withdrawal by that category of users. (2) More broadly, water use pertains to the interaction of humans with and their influence on the hydrologic cycle, and includes elements such as water withdrawal, delivery, consumptive use, wastewater release, reclaimed wastewater, return flow, and instream use. See also offstream water use and instream water use.

water use transaction a water use activity that is a withdrawal, water delivery, water release, return flow, or water transfer. See also return flow, water transfer, or water withdrawal.

water withdrawal water removed from the ground or diverted from a surface-water source for use. See also offstream water use.

watershed hydrologically based watershed delineation assigned a 10-digit hydrologic unit code (HUC). 



\section{Appendixes 1-3}


Appendix 1. Description of the Watershed Boundary Dataset.

The Watershed Boundary Dataset (WBD) defines the areal extent of surface-water drainage to a point, accounting for all land and surface areas. Watershed boundaries are determined solely upon science-based hydrologic principles, not favoring any administrative boundaries or special projects, nor any particular program or agency (U.S. Geological Survey, 2014d, and U.S. Department of Agriculture, Natural Resources Conservation Service, 2014). The purpose of defining Hydrologic Units (HUs) for the WBD is to establish a base-line drainage boundary framework, accounting for all land and surface areas. At a minimum, the WBD is being delineated and geo-referenced to the USGS 1:24,000-scale topographic base map meeting National Map Accuracy Standards (NMAS). Hydrologic units are given a Hydrologic Unit Code (HUC) (table 1-1). For example, a hydrologic region has a 2-digit HUC. A HUC describes where the unit is in the country and the level of the unit.

The WBD is being developed under the leadership of the Subcommittee on Spatial Water Data, which is part of the Advisory Committee on Water Information (ACWI) and the Federal Geographic Data Committee (FGDC). The U.S. Department of Agriculture (USDA) Natural Resources Conservation Service (NRCS), along with many other Federal agencies and national associations, have representatives on the Subcommittee on Spatial Water Data.

Table 1-1. Watershed definitions for the United States.

\begin{tabular}{lccc}
\hline \multicolumn{4}{c}{ Watershed definitions } \\
\hline Region & 1 & 2 & $\begin{array}{c}\text { Number of hydrologic unit } \\
\text { codes (HUCs) }\end{array}$ \\
\hline Subregion & 2 & 4 & 21 \\
Basin & 3 & 6 & 222 \\
Subbasin & 4 & 8 & 352 \\
Watershed & 5 & 10 & 2,149 \\
Subwatershed & 6 & 12 & 22,000 \\
\hline
\end{tabular}

Appendix 2. Hydrologic Subbasins, Watersheds, and Subwatersheds in the Delaware River Basin.

The Delaware River Basin includes 13 subbasins, 86 watersheds, and 427 subwatersheds. The hydrographic classification scheme used for this report and in the following summary tables is from the Watershed Boundary Dataset (WBD) that is described in Appendix 1.

The tables in this appendix list the subbasins within the Delaware River Basin and their associated watersheds and subwatersheds, along with their hydrologic unit codes and names. A map of each subbasin that shows the watershed and subwatershed boundaries within that subbasin is included; each subwatershed is labeled by the last four digits of the Hydrologic Unit Code (HUC). Also included is a map that shows the location of each subbasin within the Delaware River Basin.

Appendix 2 is available online at http://pubs.usgs.gov/sir/2015/5142/appendix/sir20155142_appendix2.

Appendix 3. Delaware River Basin Water Use by Subbasin.

The summaries of water use information by hydrologic subbasin in this Appendix present withdrawals by water use categories. Population and land area totals also are listed along with a map that shows the location of the subbasin within the Delaware River Basin.

In each of the summaries, a table lists average daily withdrawals for the water use categories in the subbasin. If there are no withdrawals for a particular category, that category is not listed. The withdrawals are totaled by source of water used (groundwater or surface water) and by category, and the percentage by source is indicated.

In the tables, categories were listed as withdrawing 0 million gallons per day $(\mathrm{Mgal} / \mathrm{d})$ if the withdrawal was less than $0.01 \mathrm{Mgal} / \mathrm{d}$. As a result, some totaled withdrawals from these tables may be less than the totals for public supply or industry in the water use-category table. Numbers were summed using three decimal places and then rounded to two decimal places for the final number. Values may not sum to totals because of independent rounding.

Appendix 3 is available online at http://pubs.usgs.gov/sir/2015/5142/appendix/sir20155142_appendix3. 
Prepared by USGS West Trenton Publishing Service Center. Edited by Valerie M. Gaine.

Graphics and layout by Timothy W. Auer.

GIS maps by Scott A. Hoffman.

For additional information, contact:

Sonya Jones

Coordinator-National Water Census

U.S. Geological Survey

1770 Corporate Drive, Suite 500

Norcross, GA 30093

or visit the National Water Census Web site at: http://water.usgs.gov/watercensus 
